Uni versida d e d e S a o P a u l o

Faculdade de Ciências Farmacêuticas

Departamento de Tecnologia Bioquímico-Farmacêutica

Programa de Pós-Graduação em Tecnologia Bioquímico-Farmacêutica

Área de Tecnologia em Alimentos

\title{
DESENVOLVIMENTO DE IOGURTE PROBIÓTICO COM ADIÇÃO DE POLPA DE FRUTOS BRASILEIROS E FIBRA DIETÉTICA TOTAL
}

\author{
ANA PAULA DO ESPÍRITO SANTO
}

Tese apresentada para obtenção do grau de

DOUTOR

Orientadora: Prof ${ }^{\text {a }}$. Dr ${ }^{\text {a }}$. Maricê N. Oliveira

Co-Orientador: Prof. Dr. Attilio Converti

\section{São Paulo}



Ana Paula do Espírito Santo

\section{DESENVOLVIMENTO DE IOGURTE PROBIÓTICO COM ADIÇÃO DE POLPA DE FRUTOS BRASILEIROS E FIBRA DIETÉTICA TOTAL}

Tese apresentada ao Programa de Pós-Graduação em Tecnologia Bioquimico-Farmaceutica da Faculdade de Ciências Farmacêuticas da Universidade de São Paulo, como requisito parcial para obtenção do título de Doutor em Tecnologia Bioquimico-Farmaceutica.

Orientadora: Prof ${ }^{a}$. Dr ${ }^{\mathrm{a}}$. Maricê N. Oliveira

Co-Orientador: Prof. Dr. Attilio Converti

São Paulo

2012 
Ficha Catalográfica

Elaborada pela Divisão de Biblioteca e

Documentação do Conjunto das Químicas da USP.

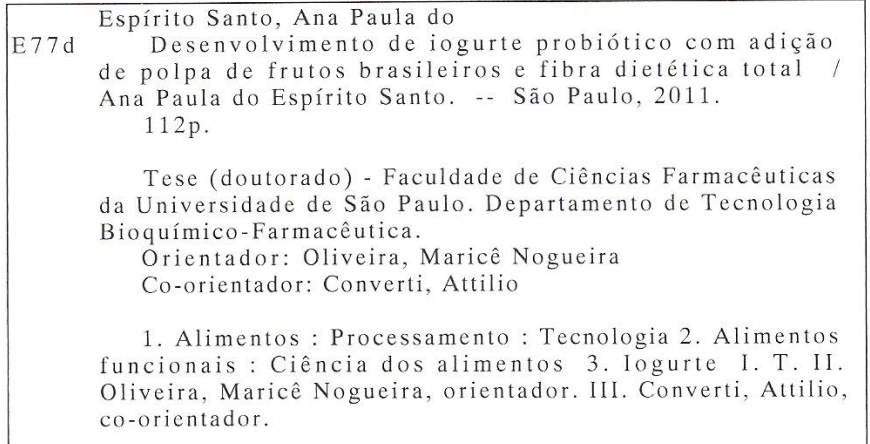


Ana Paula do Espírito Santo

\section{DEVELOPMENT OF PROBIOTIC YOGHURT WITH ADDITION OF BRAZILIAN'S FRUIT PULP AND TOTAL DIETETIC FIBER}

Comissão Julgadora da

Tese para obtenção do grau de Doutor

Prof $^{\text {a }}$. Dra ${ }^{\mathrm{a}}$. Maricê N. Oliveira
Orientadora/presidente
Prof. Dr. Attilio Converti

Co-Orientador $/ 1^{\circ}$ examinador

$2^{\circ}$. examinador

$3^{\circ}$. examinador

$4^{\mathrm{o}}$. examinador

São Paulo, 10 de fevereiro de 2012. 



\section{Agradecimentos}

Pai do Céu, obrigada! O Vosso amparo amoroso me sustenta e me concede forças.

À minha família, que me ofereceu apoio constante.

Aos Professores Dra. Maricê Nogueira de Oliveira (orientadora) e Dr. Attílio Converti (coorientador) pela orientação e incentivo à pesquisa.

Ao Prof. Dr. Luiz Antonio Gioielli, à Dra. Roberta Claro da Silva e à doutoranda Fabiana De Martini Schaeffer da Silva pelas valiosas análises de ácidos graxos.

À Professora Dra. Patrizia Perego, da Università degli Studi di Genova, por todo o apoio durante minha permanência na Itália. Grazie!

Aos alunos de iniciação científica da Faculdade de Ciências Farmacêuticas da USP: Douglas Anjos da Silva, Nathalie Scaranello Cartollano e Thaiane Ferreira da Silva, e ao aluno de tirocinio da Università degli Studi di Genova: Riccardo Motolese pela ajuda inestimável na execução de várias etapas do projeto.

À empresa DeMarcchi pela doação de polpas de açaí e de resíduos da produção de polpas de banana, maçã e maracujá.

Às empresas GlobalFood e Danisco pela doação das culturas de bactérias utilizadas durante o projeto.

Aos pós-doutorandos da Università degli Studi di Genova, Doutores: Alessandro Alberto Casazza e Bahar Aliakbarian pelo apoio e acolhimento.

Aos colegas de pós-graduação durante os estudos na Università degli Studi di Genova: Livia Seno Ferreira, Mayla Santos Rodrigues e Raquel Pedrosa pelo companheirismo. 
Às colegas de pós-graduação do laboratório de Tecnologia de Alimentos Lácteos Funcionais: Ana Carolina R. Florence, Christina S. B. Bogsan, Daniela M. Saccaro e, em especial, à Ana Lúcia O. P. Souza e Ana Paula Marafon, pela ajuda em momentos difíceis e pela amizade.

Ao técnico do Departamento de Tecnologia Bioquímico-Farmacêutica, Dr. Alexandre Mariani, que tantas vezes nos socorreu com boa vontade.

À secretária do Departamento de Tecnologia Bioquímico-Farmacêutica, Miriam Lopes, que sempre demonstrou sensibilidade e interesse em nos ajudar.

Aos funcionários do Departamento de Tecnologia Bioquímico-Farmacêutica, Ivani, Juarez, Elza e Nilton pelo apoio em diversos momentos. 


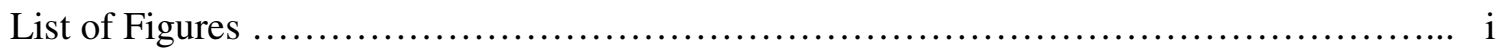

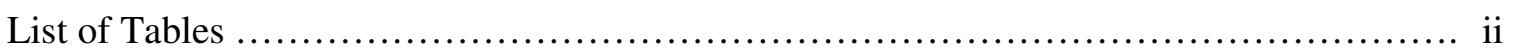

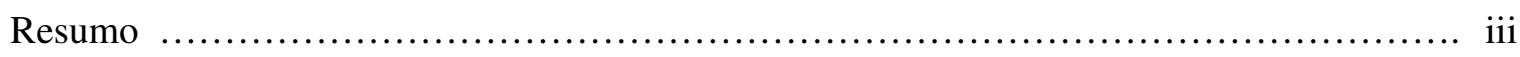

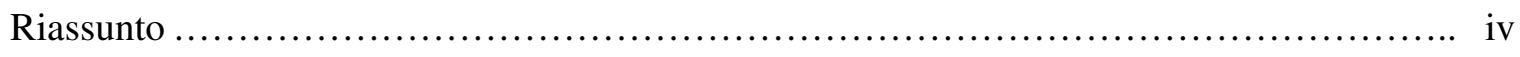

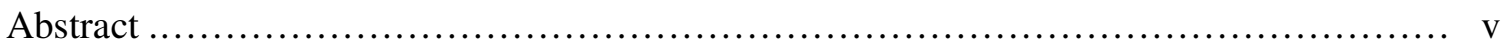

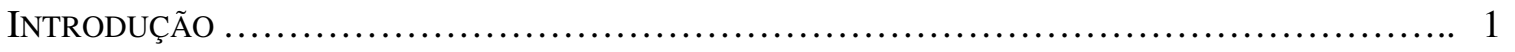

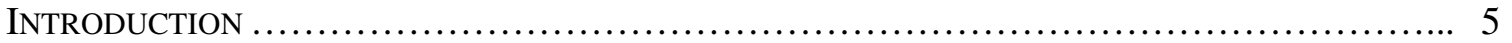

Chapter I Influence of Food Matrices on Probiotic Viability - a Review Focusing on the

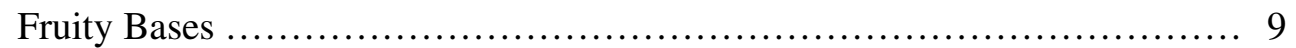

Chapter II Açai Pulp Addition Improves Fatty Acid Profile and Probiotic Viability in

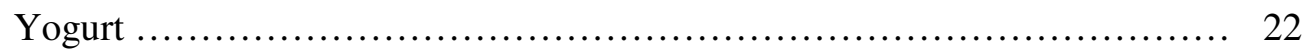

Chapter III Fibers from Fruit By-Products Enhance Probiotic Viability and

Fatty Acids Profile and Increase CLA Content in Yoghurts ............... 40

Chapter IV Influence of Milk Type and Passion Fruit Fiber Addition on Kinetics, Texture Profiles and Bacteria Viability in Probiotic Yoghurts ...................... 63

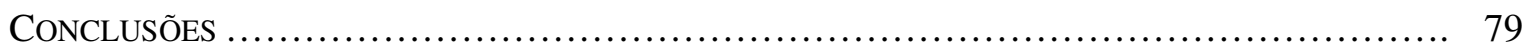

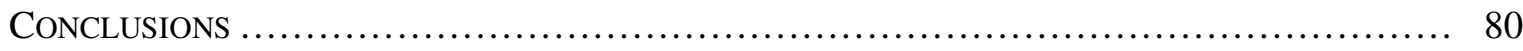

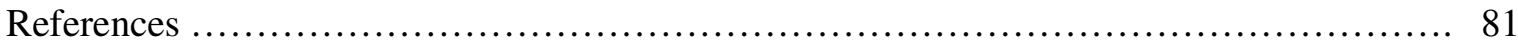


Figure 2.1. Fermentation time $\left(\mathrm{T}_{\mathrm{pH}}\right.$ 4.5) of yogurt with and without açai pulp by starter co-cultures associated with different probiotic strains

Figure 2.2. Streptococcus thermophilus counts in yogurt with and without açai pulp

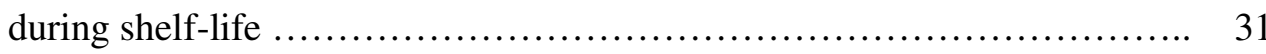

Figure 2.3. Lactobacillus delbrueckii subsp. bulgaricus counts in yogurt with and

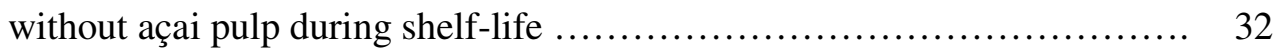

Figure 2.4. Probiotic counts in yogurt with and without açai pulp during shelf-life ..... 34

Figure 2.5. Açai (YA) and control (Y) yogurts fatty acid profile (g 100g $\mathrm{g}^{-1}$ of lipids) according to carbon chain length, observed at the day after fermentation (day 1)

Figure 3.1. Fiber powders of apple (A), banana (B) and passion fruit (C) by-products ...

Figure 3.2. Streptococcus thermophilus counts in control and fiber yoghurts cofermented by different probiotic strains ........................... 50

Figure 3.3. Lactobacillus delbrueckii subsp. bulgaricus counts in control and fiber yoghurts co-fermented by different probiotic strains

Figure 3.4. Probiotic counts in control and fiber yoghurts co-fermented by different

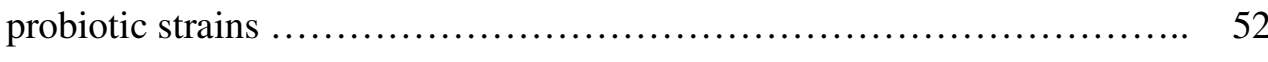

Figure 3.5. Fatty acid profiles (g/100 g of lipids), according to the saturation degree of the carbon chain, observed in control and fiber yoghurts 1 day after the fermentation by different probiotics

Figure 3.6. Contents of (A) conjugated linoleic acid and (B) $\alpha$-linolenic acid in control and fiber yoghurts co-fermented by different probiotic strains

Figure 4.1. Streptococcus thermophilus counts in control and fiber yoghurts cofermented by different probiotic strains

Figure 4.2. Lactobacillus delbrueckii subsp. bulgaricus counts in control and fiber yoghurts co-fermented by different probiotic strains

Figure 4.3. Probiotic counts in control and fiber yoghurts co-fermented by different probiotic strains 
Table 1.1. Literature survey on the influence of the fruity food matrix on the viability of probiotics and others microorganisms commonly associated to them ..... 18

Table 2.1. Experimental design to evaluate the effect of addition of açai pulp on fatty acid profile and probiotic viability in yogurt ........................ 25

Table 2.2. Post-acidification $(\mathrm{pH})$ and titratable acidity during shelf-life of yogurts with (YA) and without $(\mathrm{Y})$ açai pulp ............................ 30

Table 2.3. Fatty acid profile $\left(\mathrm{g} 100 \mathrm{~g}^{-1}\right)$ of yogurts without (Y) and with (YA) açai pulp associated with different probiotic strains ...................... 38

Table 3.1. Chemical composition in $\mathrm{g} / 100 \mathrm{~g}$ of the total dietetic fibers and the heat treated skim milk bases ........................................ 46

Table 3.2. Post-acidification $(\mathrm{pH})$ and titratable acidity of yoghurts with and without fibers during 4 weeks of cold storage $\ldots \ldots \ldots \ldots \ldots \ldots \ldots \ldots \ldots \ldots \ldots \ldots, 47$

Table 3.3. The fatty acids content in $\mathrm{g} / 100 \mathrm{~g}$ of lipids in total dietetic fibers and heat treated milk bases before fermentation ............................ 55

Table 3.4. Fatty acids content in $\mathrm{g} / 100 \mathrm{~g}$ of lipids in the yoghurts ................. 57

Table 4.1. Experimental design to evaluate the effect of addition of passion fruit fiber on texture profile and probiotic viability in yogurt made with two types of

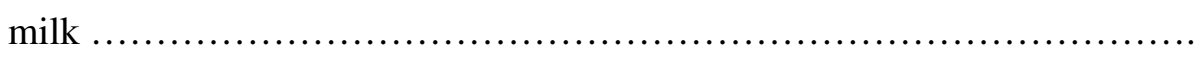

Table 4.2. Kinetic parameters of acidification of plain and skim milks fermented by starter co-culture associated with different probiotic strains with and without passion fruit fiber

Table 4.3. Post-acidification $(\mathrm{pH})$ and titratable acidity during shelf-life of control and passion fruit fiber yogurts

Table 4.4. Texture parameters of plain and skim yogurts co-fermented by different probiotic strains and with or without passion fruit fiber 


\section{RESUMO}

ESPÍRITO SANTO, A.P.; CONVERTI, A.; OLIVEIRA, M.N. Desenvolvimento de iogurte probiótico com adição de polpa de frutos brasileiros e fibra dietética total. São Paulo. 2012. 112 p. Tese (Doutorado) - Faculdade de Engenharia Química e de Processo "G. B. Bonino", Universidade de Estudo de Gênova, Itália. Faculdade de Ciências Farmacêuticas, Universidade de São Paulo. Brasil.

Novas tendências para desenvolvimento de leites fermentados com elevado valor agregados são o uso de frutos da Amazônia e a utilização de subprodutos de certas frutas como forma de aproveitamento integral do fruto e para minimizar a produção de resíduos. Dentre os frutos da Amazônia o açaí (Euterpe oleracea Mart., Arecaceae) tem o maior potencial enquanto alguns subprodutos de frutos como as cascas de maçã, banana e maracujá são promissores como ingredientes especialmente devido ao seu conteúdo em fibras dietéticas solúveis prebióticas como pectina e frutooligossacarídeos, que conferem propriedades funcionais além das características nutricionais das frutas. Assim, esse trabalho visou o desenvolvimento de iogurte probiótico com adição de polpa de frutos brasileiros e fibra dietética total. Os efeitos da suplementação do leite com polpa de açaí e fibras de maçã, banana e maracujá e, diferentes bactérias probióticas - Lactobacillus acidophilus L10, Bifidobacterium animalis ssp. lactis B104 e B94 e Bifidobacterium longum B105 na cinética de acidificação, viabilidade dos probióticos, perfil de ácidos graxos, textura, reologia e microestrutura foram estudados. A polpa de açaí favoreceu uma maior contagem de L. acidophilus L10, B. animalis ssp. lactis B104 e B. longum B105 em relação aos respectivos controles ao final de quatro semanas de vida de prateleira. Além disso, em relação aos controles sem polpa, a polpa de açaí aumentou o conteúdo de ácidos graxos mono e poliinsaturados e a produção de ácido $\alpha$ linolênico (ALA) e ácido linoléico conjugado (CLA) em iogurtes desnatados co-fermentados com B. animalis ssp. lactis cepas B104 e B94. Todas as fibras foram capazes de aumentar a concentração de ácidos graxos de cadeia curta e poliinsaturados nos iogurtes, mas, apenas as fibras de maçã e banana aumentaram a viabilidade das bactérias probióticas durante a vida de prateleira em relação aos controles sem fibra. Foi observado um efeito sinérgico entre o tipo de fibra e a cepa probiótica sobre o teor de CLA. Por outro lado, a quantidade de ALA foi significativamente aumentada pela adição de fibra de banana, independentemente da cepa probiótica utilizada. A fibra de maracujá promoveu o aumento CLA em todos os iogurtes probióticos. Os resultados demonstram, pela primeira vez, que tanto a polpa de açaí quanto as fibras oriundas do subproduto do processamento de maçã, banana ou maracujá podem melhorar o perfil de ácidos graxos e a viabilidade de bactérias probióticas. Além disso, a fibra de casca de maracujá teve um efeito positivo sobre a textura de iogurtes desnatados co-fermentados por bifidobacteria.

Palavras-chave: Iogurte; Probiótico; Textura; Viabilidade; Ácido linoléico conjugado. 


\section{RIASSUNTO}

ESPÍRITO SANTO, A.P.; CONVERTI, A.; OLIVEIRA, M.N. Sviluppo del iogurt probiotici con aggiunta di polpa di frutta brasiliana e fibra dietetici totale. 2012.112 p. Tese (Dottorato di ricerca) - Facoltà di Ingegneria Chimica e di Processo "G. B. Bonino", Università degli Studi di Genova, Itália. Facoltà di Scienze Farmaceutiche, Università di São Paulo, São Paulo, Brasile.

Nuove tendenze per lo sviluppo di prodotti fermentato di latte con alto valore aggiunto sono l'uso dei frutti delle Amazzoni e l'utilizzo di alcuni sottoprodotti della frutta come un modo per sfruttare al massimo il frutto e per minimizzare la produzione di rifiuti. Tra i frutti dell'Amazzonia l'açai (Euterpe oleracea Mart., Arecaceae) ha il maggior potenziale e come sottoprodotti di alcuni frutti la mela, banana e frutto della passione come ingredienti sono particolarmente promettenti per il suo contenuto di fibra alimentare, come prebiotico - pectina e fruttooligosaccaridi solubile, che conferiscono proprietà funzionali in aggiunta alle caratteristiche nutrizionali della frutta. Quindi, questo studio a come scopo lo sviluppo di yogurt probiotico con polpa di frutta dal Brasile e fibra alimentare totale. Gli effetti della supplementazione di latte con fibra di polpa di açai e frutta mela, banana e frutto della passione, e differenti batteri probiotici - Lactobacillus acidophilus L10, Bifidobacterium animalis ssp. B104 lactis e Bifidobacterium longum B105, B94 en la cinetica di acidificazione, viabilità dei probiotici, profilo degli acidi grassi, consistenza, reologia e microstruttura sono stati studiati. La polpa di açaí ha aumentato la conta di L. acidophilus L10, B. animalis ssp. lactis B104 e B. longum B105 dopo 28 giorni di conservazione. Inoltre, l'aggiunta di polpa di açaí ha aumentato il contenuto di acidi grassi mono e polinsaturi negli yogurt probiotici e la produzione degli acidi $\alpha$-linolenico (ALA) e linoleico coniugato (CLA) in yogurt co-fermentati con B. animalis ssp. lactis, ceppi B104 e B94. Le fibre di mela e banana hanno aumentato la vitalità probiotica durante la shelf-life, mentre tutte le fibre sono state in grado di aumentare il contenuto in acidi grassi a catena corta e acidi grassi polinsaturi degli yogurt rispetto ai corrispondenti controlli senza fibra. È stato osservato un effetto sinergico tra il tipo di fibra ed il ceppo probiotico sul contenuto di CLA, e la quantità di ALA è risultata maggiore negli yogurt fermentati con fibra di banana. La fibra del frutto della passione ha promosso un incremento significativo nel contenuto di CLA in tutti gli yogurt in rispetto ai controlli. I risultati dimostrano, per la prima volta, che le fibre di frutta sono in grado di migliorare il profilo di acidi grassi di yogurt probiotici e sottolineano l'opportunità di utilizzare le fibre dei sottoprodotti della lavorazione di frutta per sviluppare nuovi latti fermentati ad alto valore aggiunto. La fibra del frutto della passione ha ridotto significativamente il tempo di fermentazione in tutti gli yogurt scremati, ad eccezione di quello cofermentato da B. lactis B104, e promosso un aumento significativo della conta di B. lactis B104 nello yogurt. In generale, il tipo di latte ha influenzato la conta dei probiotici più che la presenza di fibra. Dopo quattro settimane di conservazione a freddo, la fermezza, la consistenza (ad eccezione del ceppo NCFM di L. acidophilus) e la coesione sono state superiori in tutti gli yogurt scremati contenenti fibra del frutto della passione. I risultati dimostrano, per la prima volta in questo campo, che l'impiego di açaí o di sottoprodotti della lavorazione di mela, banana o frutto della passione nella formulazione di yogurt probiotici può migliorare il profilo di acidi grassi e la vitalità di batteri probiotici. Inoltre, la fibra del frutto della passione ha contribuito a migliorare i parametri di testura degli yogurt scremati co-fermentati da bifidobatteri.

Parole-chiave: Yogurt; Probiotici; Textura; Viabilità; Acido linoleico coniugato. 


\begin{abstract}
ESPÍRITO SANTO, A.P.; CONVERTI, A.; OLIVEIRA, M.N. Development of probiotic yoghurt with addition of Brazilian's fruit pulp and total dietary fiber. 2012. $112 \mathrm{p}$. PhD Thesis Chemical Engineering and Process Faculty "G. B. Bonino", University of Genoa, Italy. Pharmaceutial Sciences Faculty, São Paulo University, Brazil.

New trends for development of fermented milk products with high added value are the use of fruits from Amazon, and the use of by-products of certain fruits as ingredients as a way to take full advantage of the fruit and to minimize the waste. Among the fruits of the Amazon, açai (Euterpe oleracea Mart., Arecaceae) has the most potential, and byproducts of some fruits such as apple peels, banana and passion fruit as ingredients are especially promising because of its content in dietary fiber such as pectin and soluble prebiotic fructooligosaccharides, which confer functional properties in addition to the nutritional characteristics of fruits. Thus, this study aimed the development of probiotic yoghurt with added fruit pulp from Brazil and total dietary fiber. The effects of supplementation of milk with acai pulp fiber and apple, banana and passion fruit, and different probiotic bacteria - Lactobacillus acidophilus L10, Bifidobacterium animalis ssp. B104 lactis and Bifidobacterium longum B94 and B105 on the kinetics of acidification and viability of probiotics, fatty acid profile, texture, rheology and microstructure were studied. The açaí favored a higher count of L. acidophilus L10, B. animalis ssp. and B. lactis B104 B105 longum compared with their controls after four weeks of shelf life. Moreover, compared to controls without pulp, the pulp of acai increased the content of mono and polyunsaturated fatty acids and the production of $\alpha$ linolenic acid (ALA) and conjugated linoleic acid (CLA) in nonfat yogurt co-fermented with B. animalis ssp. lactis strains B104 and B94. All fibers were able to increase the concentration of short chain fatty acids and polyunsaturated fats in yogurt, but only the apple and banana fibers increased the viability of probiotic bacteria during shelf life compared to controls without fiber. We observed a synergistic effect between the type of fiber and probiotic on the CLA content. On the other hand, the amount of ALA was significantly increased by the addition of banana fiber, regardless of the probiotic strain used. The passion fruit fiber promoted an increase CLA in all probiotic yoghurts. The results point out the applicability of adding whether açai or apple, banana or passion fruit byproducts in the formulation of probiotic yoghurts to improve the fatty acids profile and to uphold the desirable probiotic counts during four weeks of cold storage. In addition, the passion fruit fiber helped to enhance the texture parameters in skim yoghurts co-fermented by bifidobacteria.
\end{abstract}

Key-words: Yoghurt; Probiotic; Texture; Viability; Conjugated linoleic acid. 


\section{INTRODUÇÃO}

O consumo de alimentos regionais é recomendado pela Organização para Alimentos e Agricultura das Nações Unidas (FAO, 2008) para o desenvolvimento sustentável das comunidades agrícolas indígenas e não indígenas em áreas de alta diversidade biológica. Entre as diretrizes da Política Nacional de Alimentação e Nutrição (Portaria no 710 de 10/06/99) consta o resgate da cultura alimentar regional de populações indígenas e não indígenas, através de ações que levem ao aumento do consumo, desenvolvimento de técnicas de processamento e comercialização de alimentos vegetais nativos. Estas ações devem passar, necessariamente, pelo crivo da segurança alimentar, que visa não apenas a quantidade, mas também, a qualidade do alimento consumido. Muitas das frutas nativas brasileiras, como o açaí (Euterpe olaeracea, Arecaceae) permanecem como curiosidades alimentares, apesar Kuskoski et al. (2005) sugerirem o aumento do consumo mundial de frutas tropicais. Um bom incentivo para a necessária integração entre os interesses sócio-econômicos e ambientais que envolvem o alimento regional é avaliar as propriedades nutricionais e funcionais dos frutos nativos e desenvolver novos produtos alimentícios com estas frutas.

A polpa de açaí tem sido considerada uma super-fruta devido à sua atividade anti-oxidante demonstrada in vitro e in vivo, principalmente devido ao seu conteúdo de compostos fenólicos, tais como a sua antocianinas (LICHTENTHALER et al, 2005). Além disso, o extrato bruto de açaí causou a vasodilatação e conseqüente redução da pressão arterial em ratos hipertensos, provavelmente com a participação de compostos fenólicos (ROCHA et al, 2007). Pesquisas mostram que a ingestão diária de frutas e vegetais ricos em compostos antioxidantes é de grande valor para prevenir o estresse oxidativo (STEINBERG, 1995). Há evidências significativas de que o consumo regular de alimentos ricos em flavonóides, reduz o risco de morte por infarto agudo do miocárdio (HERTOG et al, 1993; KNEKT, 1996), e a incidência de acidente vascular cerebral em idosos (KELI et al, 1996).

Segundo o Ministério da Agricultura do Brasil (BRASIL, 2008), a produção anual de frutos tem sido de mais de 38 milhões de toneladas, gerando cerca de 471,8 milhões dólar através da exportação de frutas frescas em 2006, o que representa um aumento de $95 \%$ em relação a 2002 . O crescimento da produção de frutos tem permanecido na ordem dos 50\% ao ano (BRASIL, 2008). Por outro lado, o desperdício de alimentos, especialmente frutas, é uma realidade em todo o mundo (FAO, 2008). No processamento de frutas para produção de polpa, em torno de $65-70 \%$ do peso do fruto é desprezado (OLIVEIRA et al., 2002), o que contribui para o agravamento do impacto ambiental gerado pelo lixo orgânico (LOUSADA Jr. et al., 2006). A tendência que começou nos 
últimos anos 70, de usar subprodutos de certas frutas como ingredientes para novos alimentos, pode ajudar a minimizar este desperdício (OLIVEIRA et al., 2002). Entre os subprodutos de frutos promissores como ingrediente para a indústria de alimentos estão as cascas de maracujá, maçã e banana, especialmente por causa do seu conteúdo em fibras dietéticas solúveis como pectina e frutooligossacarídeo, que confere propriedades funcionais, além de aspectos nutricionais da fruta (STAFFOLO et al. 2004).

A crescente demanda por alimentos funcionais tem impulsionado os investimentos na área de pesquisa e desenvolvimento pelas indústrias de alimentos (MICHIDA et al, 2006). No Brasil, o Ministério da Saúde, através da Agência Nacional de Vigilância Sanitária (ANVISA), regulamentou os Alimentos Funcionais através das resoluções: ANVISA nº 18/99 e 19/99, que preconizam que o alimento ou ingrediente que alegar propriedades funcionais ou de saúde pode produzir efeitos metabólicos e ou fisiológicos e ou manutenção geral da saúde no que diz respeito ao papel fisiológico dos nutrientes e não nutrientes e à redução de risco de doenças, não sendo permitidas alegações de saúde que façam referência à cura ou prevenção de doenças (BRASIL, 1999a; BRASIL, 1999b).

De acordo com Food Processing (2009) e Granato et al (2010), o mercado de alimentos funcionais no Brasil foi responsável por 1\% (U\$ 500 milhões) das vendas totais de alimentos em 2007 sendo a maior parte deste mercado (65 \%) composta por produtos probióticos. Mundialmente, os ingredientes, suplementos e alimentos probióticos compõe um mercado de U\$ 16 bilhões em 2008 e estima-se que o vende destes produtos pode chegar a 19,6 bilhões dólares em 2013 (GRANATO et al, 2010). O mercado de alimentos funcionais, tais como probióticos tem experimentado um crescimento constante de 5\% ao ano (STANTON et al, 2005; GRANATO et al, 2010). Entre as diversas espécies de probióticos, as do gênero Lactobacillus foi responsável por 61,9\% das vendas totais em 2007 (FOOD PROCESSING, 2009).

$\mathrm{Na}$ fabricação de produtos lácteos fermentados são empregadas bactérias ácido-láticas dos gêneros Lactobacillus, Lactococcus, Streptococcus, Leuconostoc, Bifidobacterium, Propionibacterium, que fermentam açúcares, produzindo ácido lático como principal produto da fermentação, o que acidifica o leite impedindo o desenvolvimento de bactérias nocivas à qualidade do produto final e à saúde humana (FARIA et al, 2006). Os diferentes leites fermentados apresentam fases de produção similares, como padronização do conteúdo de gordura, aumento dos sólidos não gordurosos do leite, homogeneização, desaeração e tratamento térmico. No entanto, alguns aspectos tecnológicos precisam ser observados para a manutenção da viabilidade das culturas probióticas como a determinação do tipo de cultura inicializadora mais adequada, temperatura, tempo de incubação e taxa de inoculação (FARIA et al, 2006). Uma das culturas 
inicializadoras mais utilizadas é uma mistura simbiótica de Streptococcus thermophilus e Lactobacillus delbrueckii subsp. bulgaricus. O S. thermophilus cresce rapidamente, produzindo ácido lático e dióxido de carbono a partir da lactose do leite, o que estimula o crescimento de $L$. bulgaricus (OLIVEIRA \& DAMIN, 2003). Por outro lado, a atividade proteolítica do L. bulgaricus gera peptídeos e aminoácidos que foram utilizados para a manutenção do $S$. thermophilus na cultura (OLIVEIRA \& DAMIN, 2003). Enquanto o Streptococcus é responsável pela redução do pH até, aproximadamente, 5, os Lactobacilus reduzem o $\mathrm{pH}$ até 4. Durante o processo fermentativo ocorrem mudanças na textura, aroma e sabor do leite, pela presença de ácido lático, acetaldeído, ácido acético e diacetil, que inibem a proliferação de microrganismos patogênicos (SAXELIN et al, 1999; REID et al, 2003).

Nos últimos anos, tem havido um aumento de produtos lácteos fermentados com adição de suco de frutas ou flavorizantes para melhorar a palatabilidade destes alimentos, no entanto, as frutas empregadas para este fim, quase sempre, são as adaptadas a climas temperados como maçã, morango ou pêssego (BRANDÃO, 2002). Do ponto de vista tecnológico, a adição de polpa de fruta nativa ao leite fermentado pode representar problemas ou benefícios tecnológicos, especialmente no que se refere à viabilidade dos probióticos durante a vida de prateleira do produto. Por outro lado, a presença da polpa de fruta pode incrementar os aspectos nutricionais e funcionais do alimento, especialmente no que se refere ao potencial antioxidante e ao teor de fibras prebióticas.

O desenvolvimento de produtos lácteos adicionados com frutas nativas brasileiras pode contribuir para o desenvolvimento sustentável das comunidades que habitam áreas de grande diversidade de espécies frutíferas o que, segundo Homma (2005), constitui uma excelente maneira de combater a biopirataria pois transforma os recursos da biodiversidade em atividades econômicas que geram emprego e renda para a população. Por outro lado, o uso de subprodutos do processamento de frutas como ingrediente para formulação de novos produtos alimentares com alta aceitação no mercado, como os produtos lácteos probióticos, pode ajudar a minimizar o impacto ambiental gerado pelo descarte de refugo da indústria de alimentos, além de contribuir para aumentar a ingestão de fibra dietética.

Com base nessas evidências, o principal objetivo desta tese foi o desenvolvimento de iogurte probiótico com adição de polpa de fruta brasileira e de fibra dietética total obtida dos subprodutos do processo de fabricação de polpa.

Os objetivos específicos foram:

1. Formulação de iogurtes co-fermentados por diferentes cepas de bactérias probióticas com polpa de açaí. 
a. Avaliar o efeito da adição de polpa de açaí sobre a viabilidade das bactérias inicializadoras e probióticas em iogurtes durante quatro semanas de armazenamento a frio;

b. Avaliar o efeito da polpa de açaí sobre o tempo de fermentação e sobre os parâmetros físicoquímicos, como pH, acidez total titulável e teor de lactose;

c. Determinar a influência da adição de polpa de açaí, uma fruta rica lipídios, nos perfis de ácidos graxos dos iogurtes formulados, especialmente no que diz respeito à produção de CLA.

2. Formulação de iogurtes co-fermentados por quatro diferentes cepas de bactérias probióticas adicionados de fibras dietéticas totais obtidas dos subprodutos do processamento de: maçã, banana ou maracujá.

a. Verificar o possível efeito prebiótico das fibras dietéticas totais sobre as cepas probióticas testadas;

b. Analisar do pós-acidificação e acidez titulável total;

c. Avaliar as mudanças no perfil de ácidos graxos dos iogurtes promovido pela combinação de fibras de frutas e diferentes cepas probióticas.

3. Formulação de iogurtes integrais e desnatados co-fermentados por quatro diferentes cepas de bactérias probióticas com fibra dietética total de cascas de maracujá, comparar o efeito do tipo de leite e da adição de fibra de maracujá sobre:
a. Parâmetros cinéticos;
b. Pós-acidificação;
c. Contagem de bactérias inicializadoras e probióticas durante quatro semanas de armazenamento a frio;
d. Parâmetros de textura. 


\section{INTRODUCTION}

The recovery of regional foods is recommended by Food and Agriculture Organization of the United Nations (FAO, 2008) for the sustainable development of indigenous and non-indigenous farming communities in areas of high biological diversity. The enhancement of regional food culture of, through actions that lead to the increase consumption of products based on native plants is among the directives of the Brazilian National Policy on Food and Nutrition (Order $\mathrm{n}^{\mathrm{o}} 710$, 10/06/99); (BRASIL, 2003). These actions must pass, necessarily, by the sieve of food safety, which aims not only the quantity but also the quality of the food consumed.

Many of the Brazilian native fruits such as açaí (Euterpe olaeracea, Arecaceae) remain as food curiosities, despite Kuskoski et al. (2005) have suggested the increase in the world consumption of tropical fruits. A good incentive for the necessary integration between socioeconomic and environmental interests involving the regional food is to assess the nutritional and functional properties of native fruits and development of new food products with these fruits.

The açaí pulp has been considered a super-fruit due to the considerable anti-oxidant activity of its phenolic compounds such as anthocyanins (LICHTENTHALER et al, 2005). In addition, the crude extract of açaí caused the vasodilation and consequent reduction in blood pressure in hypertensive rats, probably with the participation of phenolic compounds (ROCHA et al, 2007). Some surveys show that the intake of fruits and vegetables rich in antioxidant compounds is of great value to prevent oxidative stress (STEINBERG, 1995). There is significant evidence that regular consumption of foods rich in flavonoids reduces the risk of death from acute myocardial infarction (HERTOG et al., 1993; KNEKT, 1996), and the incidence of stroke in elderly (KELI et al, 1996).

According to the Brazilian Ministry of Agriculture (BRASIL, 2008), the annual fruit production has being over 38 million tons, generating US\$ 471.8 million through exportation of fresh fruits in 2006, representing an increase of 95\% compared to 2002. The growth of fruit production has remained the order of $50 \%$ per annum (BRASIL, 2008). Moreover, the waste of food, especially fruit, is a worldwide reality (FAO, 2008). In the processing of fruit for pulp production, around $65-70 \%$ of the fruit weight is despised (OLIVEIRA et al., 2002), which contributes to worsening environmental impact generated by organic waste (LOUSADA Jr. et al., 2006). The trend, which began in the last 70's, to use by-products of certain fruits as ingredient for new foods, can help minimize this waste (OLIVEIRA et al., 2002). Among the promising fruits byproducts as ingredient for food industry are the peels of passion fruit, citrus and banana, especially because of its content in soluble dietary fibers such as pectin and fructooligosaccharide, which confers functional properties in addition to nutritional aspects of fruit (STAFFOLO et al. 2004). 
The growing demand for functional foods has driven investments in the area of research and development by the food industries (MICHIDA et al, 2006). In Brazil, the Ministry of Health through the National Health Surveillance Agency (ANVISA), requires that the food or ingredient that claim functional properties is not allowed to make reference to the cure or prevention of disease (BRASIL, 1999a; BRASIL, 1999b). For those nutrients with functions fully recognized by the scientific community, will not need the demonstration of effectiveness or analysis of the same claim for functional in labelling (ANVISA, 3.3 of Resolution No. 18, 2009).

According to Food Processing (2009) in Granato et al (2010), the market of functional foods in Brazil was responsible for 1\% (US\$ 500 thousand) of the total food sales in 2007 and, the major part of this market (65\%) is composed by probiotic products. Globally, the probiotic ingredients, supplements, and foods make a market of US\$16 billion in 2008 and is estimated that the sells of these products can reach US\$19.6 billion in 2013 (GRANATO et al, 2010). The market for functional foods such as probiotics has experienced a steady growth of 5\% per year (STANTON et $a l, 2005$; GRANATO et al, 2010). Amongst the diverse species of probiotics, the Lactobacillus genus is responsible for $61.9 \%$ of total sales in 2007 (FOOD PROCESSING 2009).

In the production of fermented milk are employed some genera of acid-lactic bacteria such as Lactobacillus, Lactococcus, Streptococcus, Leuconostoc, Bifidobacterium and Propionibacterium, which can ferment sugars preventing the development of harmful microorganisms to human health and to the quality of final product (FARIA et al, 2006). The various fermented milk products have similar stages of production, such as fat content standardization, increase in non-fat dry milk, homogenization, de-aeration and heat treatment. Peculiarities of the technological process of production of fermented milks concern mainly to the rate of inoculation, temperature of fermentation, final $\mathrm{pH}$ and, in the production of probiotic products, the selection of the probiotic cultures (FARIA et al, 2006).

One of the most used starter cultures is a symbiotic mix of Streptococcus thermophilus and Lactobacillus delbrueckii subsp. bulgaricus. The S. thermophilus grows rapidly, producing lactic acid and carbon dioxide from the lactose in milk, which stimulates the growth of L. bulgaricus. Moreover, the proteolytic activity of L. bulgaricus generates peptides and amino acids to be used for the maintenance of $S$. thermophilus in culture (OLIVEIRA \& DAMIN, 2003). While Streptococcus thermophilus is responsible for reducing the $\mathrm{pH}$ to approximately 5, the Lactobacillus bulgaricus reduces the $\mathrm{pH}$ until 4. During the fermentation process, occur changes in texture, aroma and flavor of milk because of the presence of lactic acid, acetaldehyde, acetic acid and diacetil, which inhibit the proliferation of pathogenic microorganisms (SAXELIN et al, 1999; REID et al, 2003). 
In recent years, there has been an increase in new fermented milk products with addition of fruit juice or flavoring agents to improve the palatability of food. Nevertheless, the fruit used for this purpose, such as apple, strawberry or peach are adapted to temperate climates (BRANDÃO, 2002). From the technological point of view, the addition of native fruit pulp to the fermented milk can provide technological benefits or problems, especially regarding the viability of probiotics during the shelf life of the product. Moreover, the presence of the fruit pulp can increase the functional aspect of the product, especially the antioxidant potential and prebiotics fiber content.

The development of dairy products added with Brazilian native fruit may contribute for sustainable development of communities that inhabit areas of great diversity of plant species because, according Homma (2005), the best way to fight biopiracy is to transform the resources of biodiversity in economic activities that generate employment and income for the population. Similarly, the use of by-products from the processing of fruits as ingredient new food products with high market acceptance, as the probiotics dairy products, can help minimize the environmental impact and increase the intake of dietary fiber.

Based on these evidences, the major aim of this Thesis was the development of probiotic yoghurt with addition of Brazilian's fruit pulp and total dietary fiber.

The specific objectives were:

1. Formulation of yoghurts co-fermented by different strains of probiotic bacteria with açaí pulp.

a. Evaluate the effect of açai pulp addition on the viability of starter and probiotic bacteria in the formulated yogurts during four weeks of cold storage;

b. Asses the effect of açai pulp on fermentation time and physical-chemical parameters such as $\mathrm{pH}$, titratable acidity and lactose content;

c. Determine the influence of the addition of açaí pulp, a lipids rich fruit, on the fatty acid profiles of the yoghurts, especially on the CLA production.

2. Formulation of yoghurts co-fermented by four different strains of probiotic bacteria with total dietetic fiber from apple, banana and passion fruit processing by-products:

a. Verify the possible prebiotic effect of the fruit total dietary fibers on the probiotic strains tested;

b. Analyse of the post-acidification and total titratable acidity;

c. Evaluate the changes on the fatty acids profile of the yoghurts promoted by the combination of fruit fibers and different probiotic strains. 
3. Formulation of plain and skim yoghurts co-fermented by four different strains of probiotic bacteria with total dietetic fiber from passion fruit rinds, compare the effect of the milk type and of the passion fruit fiber on:
a. Kinetic parameters;
b. Post-acidification;
c. Counts of starter and probiotic bacteria during four weeks of cold storage;
d. Texture parameters 


\section{CHAPTER I}

\section{INFLUENCE OF FoOd MATRices ON Probiotic ViabiLity - A REVIEW Focusing On THE Fruity BaSES}

\subsection{Introduction}

Gut health is a common target in the development and consumption of functional foods, and some market figures point out this reality, showing that a large part of the sales in the sector is due to the different types of fermented milks, mainly yoghurts (GRANATO et al., 2010). Moreover, when developing nutritionally designed foods that promote health through gut microbial reactions, three different types of food ingredients can be used: living microorganisms (probiotics), nondigestible carbohydrates (dietary fiber and prebiotics), and bioactive plant secondary metabolites such as phenolic compounds (PUUPPONEN-PIAMIÄ et al., 2003). Considering that there are scarce studies that point out the effects of fruity food matrices on probiotic microbiota. The aim of this review is to provide an overview of recent studies on the interactions between the probiotic viability/activity and the food product, especially those containing a fruity base.

\subsection{Gut microbiota}

Components of the human microbiota and of the food entering the gut may have destructive or beneficial effects on human health.

The human gut is the natural habitat for a large and dynamic bacterial community, but a substantial part of it is still uncharacterized or unculturable (MACFARLANE \& MACFARLANE, 2004; ECKBURG et al., 2005; FRANK \& PACE, 2008; TURRONI et al., 2008). Gut microbiota within a given individual are remarkably stable, although major differences may exist among different persons. The colon is certainly a host to a stable ecosystem, whereas the ecosystem of the small intestine is less stable and more susceptible to modifications (BEZKOROVAINY, 2001).

Recently the expressions 'normobiosis' and to 'dysbiosis' are well defined and allow for better understanding of microbiota behavior. Normobiosis characterizes a composition of the gut 'ecosystem' in which microorganisms with potential health benefits predominate in number over 
potentially harmful ones, in contrast to dysbiosis, in which one or a few potentially harmful microorganisms are dominant, thus creating a disease-prone situation (ROBERFROID et al., 2010).

The significance and effect of resident bacteria on a host's physiology and pathology have been well documented. Major functions of the gut microbiota include metabolic activities that result in save of energy and absorbable nutrients, important trophic effects on intestinal epithelia and on immune structure and function (PERDIGON et al., 2002; ISOLAURI, 2004; KELLY et al., 2005), and protection of the colonized host against invasion by foreign microbes (GUARNER \& MALAGELADA, 2003). Gut microbiota might also be an essential factor in certain pathological disorders, including multisystem organ failure, colon cancer, inflammatory bowel diseases (SALONEN et al., 2010), and recently there are signs that it acts in obesity (ISOLAURI et al., 2009; DIBAISE et al., 2008; FURTADO et al., 2010; SCARPELLINI et al., 2010). Probiotics have been identified as promoters of the host well-being, in spite of the inconsistency in reporting the results, which may be due to differences in the strains used, in routes of administration and doses (ADOLFSSON et al., 2004).

\subsection{Probiotics and prebiotics}

A probiotic is a viable microbial dietary supplement that beneficially influences the host through its effects in the gut (FAO/WHO, 2002). On the other hand, prebiotics are products that strengthen normobiosis by a) selective modification in the gut microbiota's composition, b) improving feces formation by increasing the water-holding capacity and gelification of the faecal material, c) beneficial physiological effects either in the colon or the extra-intestinal compartments or d) reduction of the risk of dysbiosis and associated intestinal and systemic pathologies (ROBERFROID et al., 2010).

Probiotics and prebiotics are known to have a role in prevention or treatment of some diseases (GUARNER \& MALAGELADA, 2003; GAREAU et al., 2010). Only little changes are noticed in the microbial profile of the feces of children and elderly as the result of probiotics daily intake. However, when applied to pathologic situations, they are often sufficient to beneficially alter the course of disease. In most situations, probiotic administration results in an increase in fecal counts of bifidobacteria and lactobacilli, a decrease in fecal $\mathrm{pH}$, a decline in those bacterial enzyme activities that are associated with the development of colon cancer, and then in beneficial effects in many diseases (BEZKOROVAINY, 2001; COLLADO et al., 2009; GAREAU et al., 2010). 
There are many factors that impact on the survival of ingested probiotics in the gastrointestinal tract as the level of stomach acidity, the time of exposure to acid, the concentration of bile salts and time of exposure to them, the level of bile salt hydrolase activity, and the probiotic species and strains used. Nevertheless, many probiotic strains can withstand the rigors of passage through the upper gastrointestinal tract and enter the colon in a viable state in sufficient number to affect the micro ecology and metabolism in the colon. Moreover, there are evidences in vivo that some bacteria strains adhere to intestinal mucosal cells, avoiding that pathogens exert their deleterious activity in a significant extent, but colonization may be unnecessary to achieve positive results in probiotic therapy. When probiotic administration stops, they are no longer recovered in a feces, which indicates that, although not colonizing, these bacteria continue to be metabolically active, thus providing health benefits to their hosts. Thus, to assure the beneficial effect, regular ingestion is recommended, even though, apparently, culturable stability data alone do not give a sufficient accurate prediction of the probiotic functionality under adverse conditions (e.g. survival under acidic and bile stress). In spite of having no agreement about the effective dose, many authors have been suggesting a minimum dose between $10^{6}-10^{9} \mathrm{CFU} /$ day to assure the therapeutic effect (VASILJEVIC \& SHAH, 2008).

The enumeration of probiotic bacteria from yoghurt-like products is a challenge due to the presence also of Streptococcus thermophilus and Lactobacillus delbrueckii ssp. Bulgaricus. Considering the probiotic bacteria found in commercial fermented milks, the most usual selective medium for their enumeration in yoghurt-like products are: (a) deMan Rogosa Sharp (MRS) agar, at pH 6.2, with $10 \mu \mathrm{L} \mathrm{mL}{ }^{-1}$ clindamycin, for Lactobacillus acidophilus or with $0.5 \mu \mathrm{L} \mathrm{mL}^{-1}$ of vancomycin for Lactobacillus rhamnosus, (b) LC agar for Lactobacillus casei which was developed by RAVULA \& SHAH (1998), (c) Reinforced Clostridial Agar (RCA) with 5\% of cystein, at pH 7.1, plus $100 \mu \mathrm{L} \mathrm{mL}^{-1}$ dicloxacillin for bifidobacteria (LANKAPUTHRA \& SHAH, 1996; DAVE \& SHAH, 1996; THARMARAJ \& SHAH, 2003). Probiotic microorganisms have a satisfactory growth under anaerobic conditions at $37^{\circ} \mathrm{C}$ and can be enumerated after $48-72 \mathrm{~h}$.

\subsection{Dairy products}

There are evidences that the food matrices play an important role in the beneficial health effects of probiotics on the host. Research now focuses both on characterizing specific probiotic strains and how the food matrix and the dietary content interact with the most efficient probiotic 
strains (ISOLAURI, 2007). When choosing a cryoprotectant for a probiotic, also the stability in target food applications should be considered (SAARELA et al., 2006).

Yoghurt-like products is considered the best-known food vehicle for probiotics because, beyond its own physico-chemical and functional characteristics, the beneficial effects of LAB present in the fermented milk are associated with health by the consumers so far (VASILJEVIC \& SHAH, 2008).

Briefly, yoghurt is defined as a coagulated milk product that results from fermentation of milk by S. thermophilus and L. delbrueckii ssp. bulgaricus (LAB). The conversion of lactose into lactic acid lowers the $\mathrm{pH}$ and, consequently, favors the precipitation of milk proteins. When the desired $\mathrm{pH}$ (usually around 4.5-4.7) is reached, the gel is broken by passing it through a filter system and immediately cooled to $20^{\circ} \mathrm{C}$, which slows down the fermentation and facilitates the transfer of yoghurt to the package and limits changes in the structure of the gel. The product is then cooled to $4^{\circ} \mathrm{C}$ and maintained at this temperature during storage, transport and distribution. Though S. thermophilus and L. delbrueckii ssp. bulgaricus cannot be considered probiotics according to FAO/WHO (2002), the influence of fruity matrix on these microorganisms will be refereed in this review, since they are often associated with probiotic strains in food products and in clinical trials (MERENSTEIN et al., 2010; SIMRÉN et al., 2010).

Several LAB species are currently used in the manufacture of yoghurt including probiotics, and supplementation of milk with functional ingredients is proposed to develop new yoghurts.

However, although the fruit-added fermented milks are responsible for more than a half of the yoghurt-like products market, only a few publications on these dairy products enriched with fruity bases are available in literature, and data regarding the possible impact of these fruits on the viability of the probiotic microorganism in the food product and in the consumer microbiota are scarce (VINDEROLA et al., 2002). One of the main concerns in the probiotic fruit yoghurt production is the acidic environment that most of the fruits may confer to the product (KAILASAPATHY et al., 2008).

The viability of strains of L. acidophilus and Bifidobacterium animalis ssp. lactis in stirred yoghurts with fruit preparations of mango, mixed berry, passion fruit and strawberry was evaluated during shelf-life (GODWARD et al., 2000; KAILASAPATHY et al., 2008). The authors observed that the addition of any of the fruit preparations in different concentrations had no effect on the counts of the two probiotics tested. Similar findings were reported by Bakirci and Kavaz (2008), who observed that the counts of S. thermophilus, L. acidophilus and Bifidobacterium sp. Did not exhibit any significant difference in fermented milks supplemented with banana puree, compared to 
the control. On the other hand, Donkor et al. (2007) observed a reduction of viable population of Bifidobacterium animalis Bb-12, L. acidophilus La-5 and L. rhamnosus GG during 28 days-cold storage in commercial fermented milks, as a consequence of $\mathrm{pH}$ decrease due to lactic and acetic acids and acids derived from fruit juice flavourings (Table 1.1).

Strains of L. acidophilus and Bifidobacterium bifidum were able to maintain their viability in yoghurt containing açai pulp at different concentrations (ALMEIDA et al., 2008). In a different approach, Espirito-Santo et al. (2010) observed that the addition of $7 \%$ of açai pulp prior to the fermentation of milk increased the monounsaturated and polyunsaturated fatty acid contents and enhanced the production of $\alpha$-linolenic and conjugated linoleic acids in the probiotic yoghurt. Moreover, açai pulp favored the viability of L. acidophilus, B. animalis ssp. lactis and Bifidobacterium longum throughout 4 weeks of cold storage (ESPIRITO-SANTO et al., 2010).

The fermented milks supplemented with lemon and orange fibers increased the counts of L. acidophilus and L. casei during cold storage compared to the control, but it was not so for B. bifidum, possibly owing to the well-known sensitivity of bifidobacteria species to the acidic environment (SENDRA et al., 2008).

The association of Saccharomyces boulardii with yoghurt bacteria has been suggested as a factor stimulating the viability of probiotic bacteria. Lourens-Hattingh \& Viljoen (2001), who investigated the ability of this probiotic yeast to survive in fermented milk with and without a "fruit mix", found higher counts in the fruit-based products likely because of the presence of sucrose and fructose in the fruit, being this yeast unable to ferment lactose.

Table 1.1 provides a literature survey on the influence of fruit addition to food products on the probiotic viability.

\subsection{Nondairy products}

The growing demand for new probiotic foods worldwide has stimulated the development also of nondairy products, mainly exploring fruit juice as a medium for probiotics (LUCKOW \& DELAHUNTY, 2004). In this sense, VINDEROLA et al. (2002) observed that the natural fruit juices (green apple, kiwi, pineapple, peach and strawberry) added to growth liquid media exerted an inhibitory effect on S. thermophilus. Strawberry juice inhibited all probiotic strains except L. casei, whereas the pineapple and kiwi juices had a negative effect on the growth of L. acidophilus strains. Moreover, green apple juice inhibited Lactococcus lactis growth, whereas peach juice had no effect 
on any probiotic (VINDEROLA et al., 2002). Sheehan et al. (2007), testing the viability of some lactobacilli and bifidobacteria strains in orange, pineapple and cranberry fermented juices, observed that L. casei, L. rhamnosus and Lactobacillus paracasei displayed the lowest sensitivity to the acidic environment of the juices, while all probiotics showed higher counts in orange and pineapple juices compared to cranberry juice.

The counts of nine lactobacilli strains added to a commercial fruit drink (made with a fruit blend) were evaluated during 80 days of cold storage, and the resistance to simulated gastrointestinal conditions were assessed in four of them (CHAMPAGNE \& GARDNER, 2008). The probiotic viability was shown to be strain-dependent and, in general, L. rhamnosus was more resistant than L. acidophilus. The data also suggested that a month of storage in the fruit blend drink had no significant effect on the sensitivity of probiotics to bile or pancreatic enzymes.

The pomegranate juice was successfully fermented by Lactobacillus plantarum and L. delbrueckii that were capable to survive well during the first two weeks, whereas L. paracasei and L. acidophilus lost their viability (MOUSAVI et al., 2010). Nevertheless, as far as the influence of pomegranate tannins on the viability of probiotic bacteria present in the human intestinal microbiota is concerned, it was observed that lactobacilli and bifidobacteria were not affected by ellagitannins. Moreover, the addition of a byproduct of pomegranate juice making significantly stimulated the growth of Bifidobacterium breve and Bifidobacterium infantis, while punicalagins inhibited the one of pathogenic Clostridium sp. and Staphyloccocus aureus (BIALONSKA et al., 2009).

Tomato and beetroot juices proved to be potential substrates for probiotic lactic acid bacteria such as L. acidophilus, L. casei, L. plantarum and L. brevis, as all these microorganisms were capable to produce lactic acid and maintain desirable viable cell counts above $10^{6} \mathrm{CFU} / \mathrm{mL}$ during shelf-life (YOON et al, 2004; YOON et al, 2005; KLEWICKA et al., 2009). Moreover, beetroot juice fermented by $L$. casei and L. brevis proved to be beneficial for the caecum microbiota activity of rats, for this probiotic food increased both the amounts of short chain fatty acids and the counts of beneficial bacteria such as Lactobacillus sp., Bifidobacterium sp., Bacteriodes sp., and Enterococcus sp., and reduced the Enterobacteriaceae population (KLEWICKA et al., 2009).

The juice made of a blend of carrots, celery and apples also showed to be a good matrix for the growth of L. acidophilus (NICOLESCU \& BURULEANU, 2010). On the other hand, the carrot juice alone demonstrated to be a suitable base for B. lactis and B. bifidum strains, but a $45 \%$ decrease in the carotenoids contents was promoted by these microorganisms (KUN et al., 2008). However, L. rhamnosus and L. bulgaricus strains added to carrot juice, with or without inulin and 
fructooligosaccharides, demonstrated good viability independently of the prebiotic added (NAZZARO et al., 2008). In addition, the $\beta$-carotene content and antioxidant activity were preserved during one month of cold storage, thereby indicating that these nutritional components are not metabolized by Lactobacillus spp.. The observations of Kun et al. (2008) and Nazzaro et al. (2008) suggest the hypothesis that there is a possible relation between the probiotic strain and the content of carotenoids and antioxidant power.

Some studies pointed to the applicability of apple as an ingredient to improve probiotic viability in foods. Pieces of apple and pear were shown to offer a proper material for $L$. casei immobilization, being the probiotic bacteria nested in the cellulosic structure of these fruits resistant to the cheese making and ripening processes. As cellulose is not digested, Kourkoutas et al. (2006) pointed out a possible protective effect of fruit pieces during the transit through the intestinal tract, which may help L. casei to reach the colon. In other studies, L. rhamnosus also demonstrated good adherence to the surface of apple wedges (RÖßLE et al., 2010; ALEGRE et al., 2011). Although the probiotic activity of $L$. rhamnosus adhered to the surface of apple wedges is not guaranteed over 14 days of shelf life, it proved to be effective to reduce Listeria monocytogenes growth (ALEGRE et al., 2011). Apple pieces demonstrated to be also able to immobilize the potentially probiotic yeast Saccharomyces cerevisiae for grape fermentation and to maintain its viability for more than four months under freeze storage, without any decrease of its activity (KOURKOUTAS et al., 2006).

Furthermore, Osman et al. (2008) studied the anti-inflammatory activity of blueberry and some probiotic strains in a colitis model in rats. The authors reported that the counts of Enterobacteriaceae in the caecum decreased significantly in the group that received blueberry with and without probiotics. The concentration of short chain fatty acids in caecum was significantly higher in the L. plantarum group, while the L. fermentum one promoted the highest concentration of lactic acid compared with all other groups. Moreover, the combinations of blueberry and L. plantarum or L. fermentum were able to reduce bowel inflammation (OSMAN et al., 2008).

Polyphenols such as flavonoids are ubiquitous in fruits and vegetables. Parkar et al. (2008) reported that the flavonoids - naringenin, rutin, phloridzin and quercetin - may have effects on gut microbiota, among which: a) an increase in the count of beneficial bacteria such as L. rhamnosus, b) enhanced adherence of this bacterium on the gut wall, and c) inhibition of the proliferation of enteropathogens like $S$. aureus or Salmonella typhimurium. Besides, flavonoids can suffer some structural modifications when submitted to fermentation. For instance, Bisakowski et al. (2007) evaluated the flavonoidic profile of red onions fermented by L. plantarum and found alterations on the quercetin glucosides profile. After fermentation, the amounts of quercetin diglucoside and 
monoglucoside were significantly increased, which was pointed out by the authors as an advantage, having these glicosides well-recognized antioxidant activity.

The ingestion of DF can modulate the intestinal microbiota, which is able to ferment the indigestible fibers mainly into short-chain fatty acids that are absorbed by the colonocytes stimulating water and Na absorption (SEMBRIES et al., 2003). These effects were demonstrated in the study of Wang et al. (2007) who observed that a diet based on the Taiwanese yam (a fiber-rich tubercle) increased the faecal mass and short-chain fatty acids output, increased bifidobacteria counts and decreased Clostridium perfringens counts in BALB/c mice faeces. Another example of the gut microecology modulation by DF intake is provided in the work of Foo et al. (2008), who observed in the faeces of rats fed with a fiber-rich compost made of fermented fruits (lime, sugar cane and rice bran) reduction counts of Enterobacteriaceae and increased counts of beneficial LAB, whereas the decrease in plasma cholesterol concentration can be considered an important extra benefit. Costabile et al. (2008) observed that the counts of bifidobacteria and lactobacilli in human faeces were significantly higher in the group that received dietary intake of plain-grain compared to the one that received wheat bran, which demonstrates the importance of the type of dietary fiber for the gut microbiota formation.

From the technological point of view, dietary fibers have been employing as functional ingredient thanks to their prebiotic activity. Among four different dehydrated prebiotic fibers inulin, oat bran, unripe banana flour and apple fiber, used to immobilize L. casei, the oat bran was the one that promoted the greatest viability of this probiotic during cold storage (GUERGOLETTO et al., 2010). In another study with soluble fibers, the pitaya (dragon fruit) oligosaccharides were shown to be resistant to hydrolysis by gastric juice and $\alpha$-amylase and demonstrated to have a prebiotic effect on B. bifidum and L. delbrueckii strains (WICHIENCHOT et al., 2010).

\subsection{Other products}

Besides fermented milks, fruits and fruit juices, a wide variety of foods have been tested as a vehicle for the intake of different probiotic strains. For instance, fermented acerola (Malpighia emarginata) ice cream demonstrated to support probiotic bacteria viability, since the counts of $B$. longum and B. lactis kept above $10^{6} \mathrm{CFU} / \mathrm{g}$ during 15 weeks storage even in acidic products (pH 4.5) (FAVARO-TRINDADE et al., 2006). The counts of B. lactis and L. paracasei remained above $10^{7} \mathrm{CFU} / \mathrm{g}$ in the coconut flan during shelf-life (CORREA et al., 2008). 
In a recent study, pear puree fermented by Leuconostoc mesenteroides was able to maintain constant probiotic counts around $10^{9} \mathrm{CFU} / \mathrm{g}$ for 14 days (KIM et al., 2010). Banana puree was fermented by microencapsulated L. acidophilus resulting in a symbiotic product with good consumer acceptance and desirable probiotic cell counts (TSEN et al., 2004). L. plantarum showed viability in barley, wheat and malt extracts, showing the highest counts in the last medium (CHARALAMPOPOULOS \& PANDIELLA, 2010). The daily intake of a coffee mix drink containing mannooligosaccharides significantly increased the counts of Bifidobacterium sp. in human fecal microbiota (UMEMURAS et al., 2004).

Cheese offers an attractive food-based delivery vehicle for probiotic cultures and biogenic substances such as conjugated linoleic acid (CLA) and bioactive peptides. Compared with many other fermented foods, it has relatively high $\mathrm{pH}$ and fat content, a solid consistency and a higher buffering capacity (HAYES et al., 2006). Saxelin et al. (2010), comparing the recovery of a combination of L. rhamnosus GG and LC705, Propionibacterium freudenreichii subsp. shermanii JS, and B. animalis subsp. lactis Bb12 from feces of volunteers who had received those probiotics in capsules, fermented milk or cheese, found that the quantity of L. rhamnosus strains were not affected by the administration matrix. On the other hand, when consumed in cheese, the faecal counts of bifidobacteria and surprisingly of propionibacteria were lower.

Finally, Possemiers et al. (2010) evaluated chocolate as a potential protective carrier for oral delivery of a microencapsulated mixture of Lactobacillus helveticus CNCM I-1722 and B. longum CNCM I-3470. Data indicate that the coating of the probiotics in chocolate is an excellent solution to protect them against environmental stress conditions and for optimal delivery. 
Table 1.1. Literature survey on the influence of the fruity food matrix on the viability of probiotics and others microorganisms commonly associated to them.

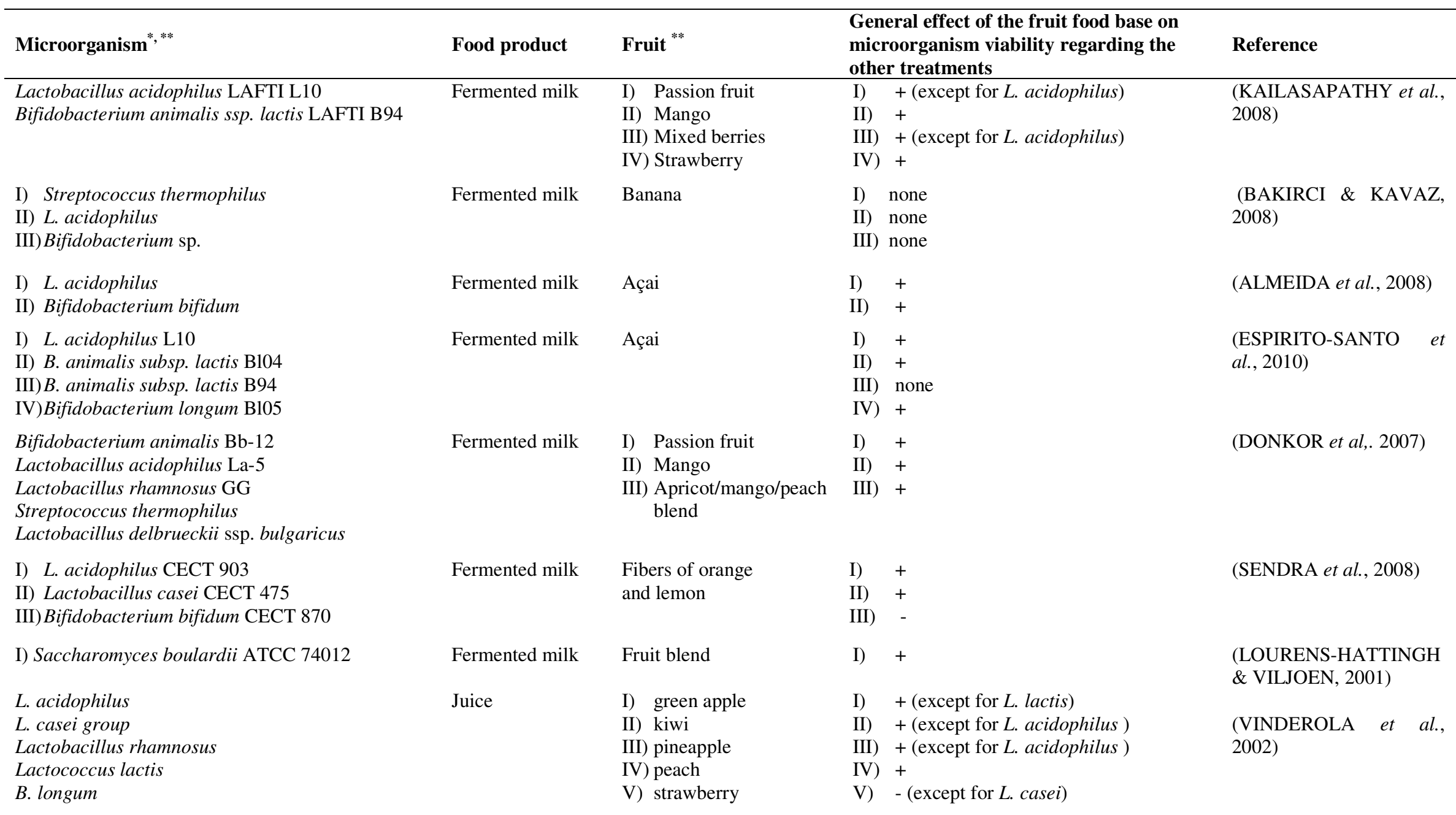




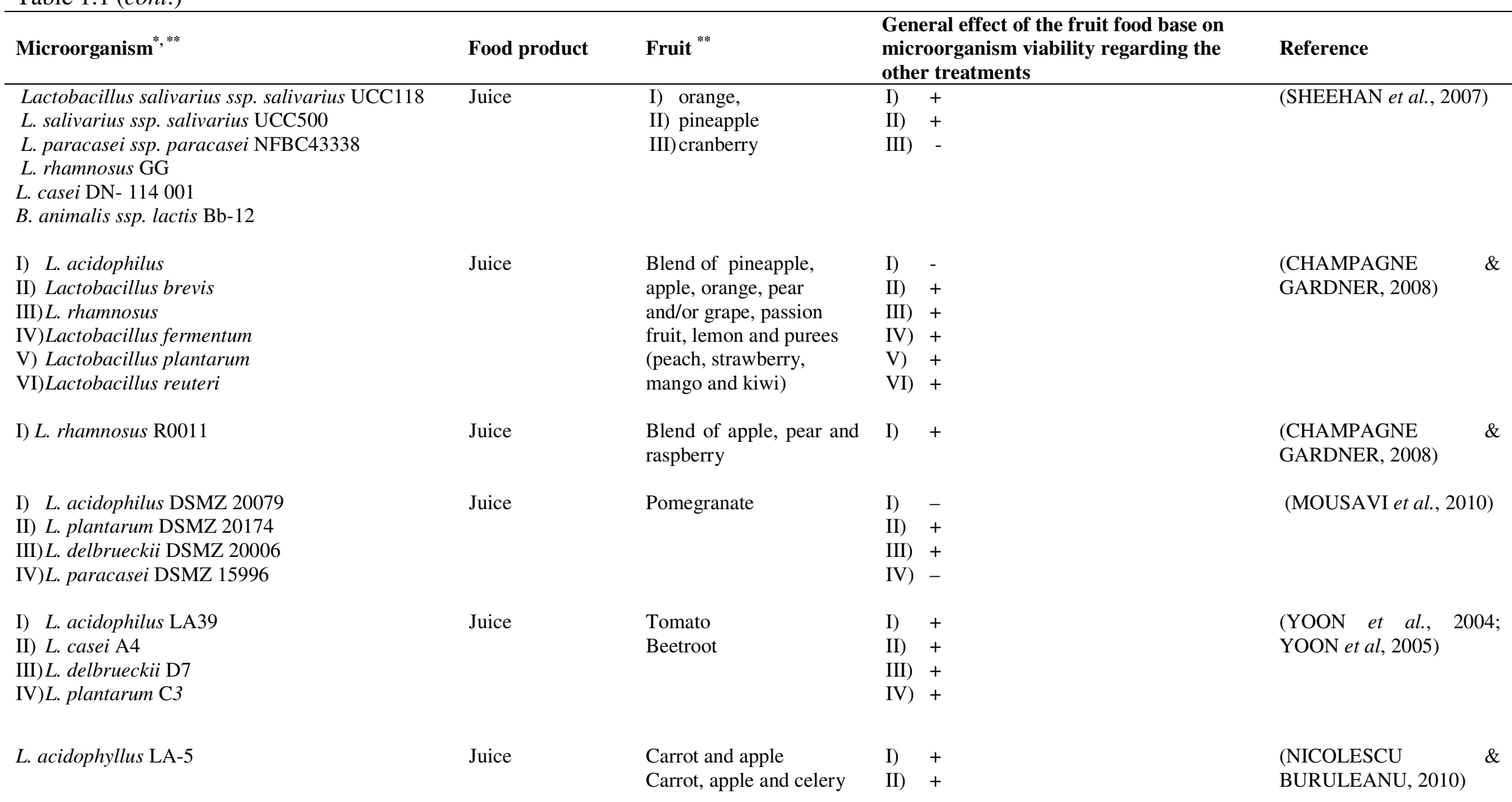




\begin{tabular}{|c|c|c|c|c|}
\hline Microorganism $^{* * * *}$ & Food product & Fruit $^{* *}$ & $\begin{array}{l}\text { General effect of the fruit food base on } \\
\text { microorganism viability regarding the } \\
\text { other treatments }\end{array}$ & Reference \\
\hline $\begin{array}{l}\text { I) } B . \text { animalis ssp. lactis } \mathrm{Bb}-12 \\
\text { II) } B \text {. bifidum (isolated from human faeces) }\end{array}$ & Juice & Carrot & $\begin{array}{lll}\text { I) } & + \\
\mathrm{II}) & +\end{array}$ & (KUN et al., 2008) \\
\hline $\begin{array}{l}\text { I) Lactobacillus delbrueckii subsp. bulgaricus } \\
\text { DSM } 20081 \\
\text { II) L. rhamnosus DSM } 20711\end{array}$ & Juice & Carrot & $\begin{array}{ll}\text { I) } & + \\
\text { II) } & +\end{array}$ & (NAZZARO et al., 2008) \\
\hline $\begin{array}{l}\text { I) Saccharomyces cerevisiae } \\
\text { II) Kluyveromyces marxianus } \\
\text { III) Lactobacillus casei }\end{array}$ & $\begin{array}{l}\text { Pieces of fruit for } \\
\text { microorganism } \\
\text { immobilization }\end{array}$ & Apple & $\begin{array}{ll}\text { I) } & + \\
\text { II) } & + \\
\text { III) } & +\end{array}$ & $\begin{array}{l}\text { (KOURKOUTAS et al., } \\
\text { 2006) }\end{array}$ \\
\hline I) L. rhamnosus GG LGG & $\begin{array}{l}\text { Pieces of fruit for } \\
\text { probiotic } \\
\text { immobilization }\end{array}$ & Apple & I) & $\begin{array}{l}\text { (RÖßLE et al., 2010) } \\
\text { (ALEGRE } \text { et al., 2011) }\end{array}$ \\
\hline I) Lactobacillus plantarum $\mathrm{S} 1$ & $\begin{array}{l}\text { Fermented } \\
\text { vegetable }\end{array}$ & Onions & I) & $\begin{array}{l}\text { (BISAKOWSKI et al., } \\
\text { 2007) }\end{array}$ \\
\hline I) Lactobacillus casei LC-1 & $\begin{array}{l}\text { Cereal / fiber for } \\
\text { probiotic } \\
\text { immobilization }\end{array}$ & $\begin{array}{l}\text { I) oat bran } \\
\text { II) banana flour } \\
\text { III) apple fiber }\end{array}$ & $\begin{array}{ll}\text { I) } & ++ \\
\text { II) } & + \\
\text { III) } & +\end{array}$ & $\begin{array}{l}\text { (GUERGOLETTO et al., } \\
\text { 2010) }\end{array}$ \\
\hline $\begin{array}{l}\text { I) Bifidobacterium animalis ssp. lactis } \\
\text { II) Bifidobacterium longum }\end{array}$ & Ice cream & Acerola & $\begin{array}{ll}\text { I) } & + \\
\text { II) } & +\end{array}$ & $\begin{array}{l}\text { (FAVARO-TRINDADE } \\
\text { et al., 2006) }\end{array}$ \\
\hline $\begin{array}{l}\text { I) Bifidobacterium animalis ssp. lactis BL04 } \\
\text { II) Lactobacillus paracasei ssp. paracasei LBC } 82\end{array}$ & Flan & Coconut & $\begin{array}{ll}\text { I) } & + \\
\text { II) } & +\end{array}$ & (CORREA et al., 2008) \\
\hline I) Leuconostoc mesenteroides & Puree & Pear & I) & (KIM et al., 2010) \\
\hline
\end{tabular}


Table 1.1 (cont.)

\begin{tabular}{|c|c|c|c|c|}
\hline Microorganism ${ }^{*}, * *$ & Food product & Fruit ${ }^{* *}$ & $\begin{array}{l}\text { General effect of the fruit food base on } \\
\text { microorganism viability regarding the } \\
\text { other treatments }\end{array}$ & Reference \\
\hline I) L. acidophilus CCRC 10695 & Puree & Banana & I) None & (TSEN et al., 2004) \\
\hline $\begin{array}{l}\text { II) L. acidophilus CCRC } 10695 \text { immobilized by } \kappa- \\
\text { carrageenan }\end{array}$ & & & II) + & \\
\hline I) Lactobacillus helveticus CNCM I-1722 & Chocolate & Cacao & I) $\quad+$ & (POSSEMIERS et al., \\
\hline II) Bifidobacterium longum CNCM I-3470 & & & II) & 2010) \\
\hline
\end{tabular}

* Some microorganisms' species were also reported with the strain identification in the study.

** The Roman numerals indicate correspondence between the variable and the effect on microorganism viability on the $4^{\text {th }}$ column.

Abbreviations: $(+)$ a significant positive effect regarding the others treatments and/or the control; $(++)$ an even more significant positive effect regarding the others treatments; (-)

a significant negative effect regarding the others treatments and/or the control. 


\section{CHAPTER II}

\section{AÇai Pulp Addition Improves Fatty Acid Profile ANd \\ Probiotic Viability in Yogurt}

\subsection{Introduction}

The consumption of regional foods is recommended by the Food and Agriculture Organization of the United Nations (FAO, 2008) for the sustainable development of indigenous and non-indigenous farming communities in areas of high biological diversity. A good incentive for the necessary integration between socio-economic and environmental interests involving regional food is the development of new food products with native fruits. The açai fruit (Euterpe oleracea, Mar., Arecaceae) is important for sustainable agribusiness in the Amazon region, where it is native (MUÑIZ-MIRET et al., 1996; SILVA et al., 2006).

Reports on biological activities of açai fruit include antioxidant activity and reduction in blood pressure in hypertensive rats (LICHTENTHÄLER et al., 2005; MERTENS-TALCOTT et al., 2008), especially due to its high anthocyanins content. Moreover, the açai pulp oil could be compared to hazelnut, olive (BENITEZ-SÁNCHEZ et al., 2003) and avocado (NASCIMENTO et al., 2008) oils, which are rich in monounsaturated $60 \%$ and polyunsaturated $14 \%$ fatty acids (MENEZES et al., 2008). This fact encourages the use of açai as an essential fatty acid source, according to the most recent US food pyramid (EKINCI et al., 2008). However the açai fatty acid profile has been under-exploited, particularly in the development of new food products.

Due to the expanding market of dairy companies, there has been a merging of dairy product and fruit beverage markets, with the introduction of hybrid dairy products, such as 'juiceceuticals', offering health, flavour and convenience (KHURANA \& KANAWJIA, 2007). The addition of açai pulp can potentially enhance the functional properties of probiotic yogurt (ALMEIDA et al., 2008). Probiotics are defined as live microorganisms that are able to colonize the gastrointestinal tract, and when administered in adequate amounts (FAO/WHO, 2001), confers a health benefit on the host beyond inherent general nutrition (such as traveler's diarrhea prevention, lowering serum cholesterol, duration of rotavirus diarrhea reduction, immune system stimulation and colon cancer prevention (FARNWORTH, 2008). 
During the fermentation of milk, fatty acid profiles progressively change as a result of microbial growth (EKINCI et al., 2008). The production of free fatty acids by lactic acid bacteria (LAB) through lipolysis of milk fat has been reported by Coskun and Ondul (2004) and Yadav et al. (2007). Kankaanpäa et al. (2004) showed that free polyunsaturated fatty acids (PUFA) in the growth medium of lactobacilli may induce changes in fatty acids, such as the degree of fatty acid unsaturation, cyclization, and proportions of PUFA containing 18 carbons with conjugated double bonds, such as conjugated linoleic acid (CLA).

Studies show that CLA can be produced by some strains of lactobacilli, bifidobacteria and propionibacteria from linoleic acid (OGAWA et al., 2005; YADAV et al., 2007; EKINCI et al., 2008). Alonso et al. (2003), Prandini et al. (2007) and Ekinci et al. (2008) reported health benefits attributed to CLA, such as protection against arteriosclerosis, modulation of immune system, and body fat reduction.

Moreover, Das and Fams (2002) observed that long chain polyunsaturated fatty acids (LCPUFAs) and have similar beneficial actions, such as the ability to restore normal and healthy gut microecology. Furthermore, both probiotics and LCPUFAs have anti-inflammatory actions alleviating changes related to allergic inflammation (DAS \& FAMS, 2002). In addition, as observed by Kankaanpäa et al. (2001), LCPUFAs, especially $\alpha$-linolenic acid, promote adhesion of Lactobacillus casei to mucosal surfaces, potentiating the beneficial actions of Lactobacilli.

Kim and Liu (2002) reported that the addition of sunflower oil increased CLA content by LAB in dairy products. Therefore, the addition of açai pulp to skim milk may increase the functional aspects of the probiotic yogurt, since it increases the content of long chain mono-and polyunsaturated fatty acids.

The objective of the present study was to evaluate the effect of açai pulp addition on fatty acid profile and probiotic viability in stirred yogurts. Moreover, the effect of açai pulp on parameters such fermentation time, $\mathrm{pH}$, titratable acidity and lactose content were also examined.

\subsection{Materials and methods}

\subsubsection{Fruit pulp}

Açai pulp (pH measured to be 4.90) was obtained from a local market at Jundiaí, Brazil. The fruit pulp was homogenized and then lyophilized in a freeze dryer (Lyolab-G, LSL Secfroid, Lausanne, Switzerland) and stored at $-20^{\circ} \mathrm{C}$ until use. In order to facilitate the mixture of açai pulp into the reconstituted milk, the particle size of freeze dried pulp was reduced to less than $42 \mu \mathrm{m}$, 
measured through sieves (Granutest, Sao Paulo, Brazil) with mesh diameters of $200 \mu \mathrm{m}, 119 \mu \mathrm{m}, 59$ $\mu \mathrm{m}$ and $42 \mu \mathrm{m}$.

\subsubsection{Milk preparation}

Skim milk powder (2 $\mathrm{g}$ fat $\mathrm{L}^{-1}$; Molico, Nestlé, Araçatuba, Brazil) was reconstituted to $12 \%$ $(\mathrm{w} / \mathrm{w})$ in distilled water and divided into two milk samples. Freeze dried açai pulp was added to one

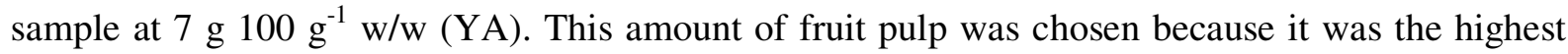
level of fruit addition that still resulted in texture expected by consumers for a spoonable yogurt (data not shown). The other milk sample was used as control, i.e., without the addition of açai pulp (Y). Both milk bases were thermally treated at $85^{\circ} \mathrm{C}$ for $15 \mathrm{~min}$ under agitation in a water bath and then portioned into sterile Schott flasks $(500 \mathrm{~mL})$, cooled in an ice bath, and stored at $4^{\circ} \mathrm{C}$ for $24 \mathrm{~h}$.

\subsubsection{Microbial cultures}

The freeze-dried starter yogurt culture (CY340, DSM, Moorebank, NSW, Australia) composed of Streptococcus thermophilus (St) and Lactobacillus delbrueckii subsp. bulgaricus (Lb) - and four probiotic cultures: Lactobacillus acidophilus (L10, DSM), Bifidobacterium animalis subsp. lactis (BL04, Danisco, Madison, WI, USA, and B94, DSM), and B. longum (BL05, Danisco) were used in this study. The lyophilized culture was diluted in milk (sterilized at $121^{\circ} \mathrm{C}$ for $15 \mathrm{~min}$ ) and divided into aliquots into Eppendorf ${ }^{\circledR}$ flasks and frozen at $-20{ }^{\circ} \mathrm{C}$. Before fermentation, the cultures in the Eppendorf $^{\circledR}$ flasks were thawed and diluted with $50 \mathrm{~mL}$ sterilized milk (inoculum).

Each Schott ${ }^{\circledR}$ flask containing $500 \mathrm{~mL}$ of reconstituted milk was inoculated with $1 \mathrm{~mL}$ of yogurt starter culture (St-Lb, CY340) and $1 \mathrm{~mL}$ of probiotic culture.

\subsubsection{Experimental procedure}

Ten different yogurts were prepared with açai pulp and different probiotic strains added. The experimental design is presented in Table 2.1. 
Table 2.1. Experimental design to evaluate the effect of addition of açai pulp on fatty acid profile and probiotic viability in yogurt.

\begin{tabular}{|c|c|c|c|}
\hline \multirow{2}{*}{ Micro-organisms (strain) } & \multirow{2}{*}{ Açai pulp } & \multirow{2}{*}{ Sample coding } & \multirow{2}{*}{$\frac{{ }^{1} \text { Counts }\left(\log \text { CFU } \mathbf{~ L L}^{-1}\right)}{{ }^{2} \text { Probiotic }}$} \\
\hline & & & \\
\hline $\begin{array}{l}{ }^{3} \text { Streptococcus thermophilus + Lactobacillus } \\
\text { delbrueckii subsp. bulgaricus (CY340) }\end{array}$ & - & $\mathbf{Y}$ & - \\
\hline $\mathrm{Y}+$ Lactobacillus acidophilus (L10) & - & YLa & $6.38 \pm 0.16$ \\
\hline $\begin{array}{l}\mathrm{Y}+\text { Bifidobacterium animalis subsp. lactis } \\
(\mathrm{B} 104)\end{array}$ & - & YB104 & $6.46 \pm 0.22$ \\
\hline $\mathrm{Y}+$ Bifidobacterium longum $(\mathrm{B} 105)$ & - & YB105 & $6.61 \pm 0.15$ \\
\hline $\begin{array}{l}\mathrm{Y}+\text { Bifidobacterium animalis subsp. lactis } \\
\text { (B94) }\end{array}$ & - & YB94 & $6.59 \pm 0.10$ \\
\hline Y & + & YA & - \\
\hline $\mathrm{Y}+$ Lactobacillus acidophilus (L10) & + & YALa & $6.38 \pm 0.16$ \\
\hline $\begin{array}{l}\mathrm{Y}+\text { Bifidobacterium animalis subsp. lactis } \\
(\mathrm{B} 104)\end{array}$ & + & YAB104 & $6.46 \pm 0.22$ \\
\hline $\mathrm{Y}+$ Bifidobacterium longum (B105) & + & YAB105 & $6.61 \pm 0.15$ \\
\hline $\begin{array}{l}\mathrm{Y}+\text { Bifidobacterium animalis subsp. lactis } \\
\text { (B94) }\end{array}$ & + & YAB94 & $6.59 \pm 0.10$ \\
\hline
\end{tabular}

${ }^{1}$ Means \pm standard deviation measured in the inocula.

${ }^{2} \mathrm{~N}=8$.

${ }^{3}$ Streptococcus thermophilus (St) and Lactobacillus delbrueckii subsp. bulgaricus (Lb) inocula counts

$(\mathrm{N}=40)$ were $8.15 \pm 0.21$ and $4.31 \pm 0.16 \mathrm{Log} C F U \mathrm{~mL}^{-1}$, respectively.

Abbreviations: without açai pulp (-); with açai pulp (+).

Immediately after inoculation, Schott ${ }^{\circledR}$ flask samples were transferred to water bath equipment assembled to a CINAC (Cynetique d'acidification, Ysebaert, Frépillon, France) system (SPINNLER \& CORRIEU, 1989). This system allowed continuous measurement and recording of $\mathrm{pH}$ through a program connected to a computer. Two independent batch fermentations were carried out on different days at $42^{\circ} \mathrm{C}$ up to $\mathrm{pH} 4.5$ and replicated twice. After $\mathrm{pH} 4.5$ was reached, the fermentation was interrupted by cooling the flasks to $20^{\circ} \mathrm{C}$ in an ice bath, and the fermentation time $\left(\mathrm{T}_{\mathrm{pH} 4.5}\right)$ was recorded. The coagulum was then broken by means of a perforated disk on a stainless steel rod that was moved upwards and downwards for $2 \mathrm{~min}$. The stirred yoghurt was put into 50 $\mathrm{mL}$ polypropylene cups, thermally sealed and stored at $4^{\circ} \mathrm{C}$. 


\subsection{5. $\mathrm{pH}$, titratable acidity and lactose}

The $\mathrm{pH}$ of fermented milk post-acidification was determined at days 1,14 and 28 using a $\mathrm{pH}$ meter model Q-400M1 (Quimis, São Paulo, Brazil). Titratable acidity was analysed as recommended by AOAC (1995) and lactose content was determined by the Lane-Eynon method based on the reduction of copper (AOAC, 1995). The results were expressed as the means of four replications.

\subsubsection{Microbiological analyses}

Bacterial enumerations were carried out at days 1, 14 and 28 in four replicates of each batch. Samples $(1 \mathrm{~mL})$ were diluted with $0.1 \%$ sterile peptonated water $(9 \mathrm{~mL})$. Afterwards, serial dilutions were carried out, and bacteria were counted, applying the pour plate technique (Kodaka et al., 2005). All media were obtained from Oxoid (Basingstoke, UK). In co-cultures, S. thermophilus colonies were enumerated in M17 agar whereas Lb were counted in MRS (pH 5.4), both under aerobic incubation at $37^{\circ} \mathrm{C}$ for $48 \mathrm{~h}$. All probiotic microorganisms were incubated under anaerobic conditions, provided by AnaeroGen (Oxoid), at $37^{\circ} \mathrm{C}$ for $72 \mathrm{~h}$. Enumerations of L. acidophilus were carried out in MRS (pH 6.2) plus $10 \mu \mathrm{L} \mathrm{mL}^{-1}$ clindamycin, and B. lactis B04, B94 and B. longum B105 in Reinforced Clostridial Agar plus $100 \mu \mathrm{L} \mathrm{mL}^{-1}$ dicloxacillin. Antibiotics were employed to allow selective growth of bifidobacteria. M17 and MRS media ( $\mathrm{pH}$ 5.4) were prepared according to Jordano et al. (1992) and Dave and Shah (1996), and MRS plus clindamycin according to Lankaputhra and Shah (1996). Cell concentration was expressed as Log CFU mL ${ }^{-1}$ of fermented milk.

\subsubsection{Fatty acid profiles}

Lipids were extracted in triplicate from yogurts with or without açai pulp according to ISO method 14156 (2001). Fatty acid methyl esters (FAMEs) were prepared by esterification according to ISO method 15884 (2002).

Analyses of FAMEs were carried out in a gas chromatograph, model 3400CX (Varian, São Paulo, Brazil) equipped with a split-injection port, a flame-ionization detector and a software package (Varian Star Chromatography Workstation version 5.5, Varian Inc., Palo Alto, CA,USA) for system control and data acquisition. Injections were made into a $30 \mathrm{~m}$ long fused silica capillary column with $0.25 \mathrm{~mm}$ internal diameter, coated with $0.25 \mu \mathrm{m}$ of Chrompack CP-Wax 52CB

(ChromTech Apple Valley, MN, USA), using helium as carrier gas at a flow rate of $1.5 \mathrm{~mL} \mathrm{~min}^{-1}$, 
and a split ratio of 1:50. The injector temperature was set at $250^{\circ} \mathrm{C}$ and the detector at $280^{\circ} \mathrm{C}$. The oven temperature was initially set at $75^{\circ} \mathrm{C}$ for $3 \mathrm{~min}$, then programmed to increase to $150^{\circ} \mathrm{C}$ at a rate

of $37.5^{\circ} \mathrm{C} \mathrm{min}^{-1}$, and then to $215^{\circ} \mathrm{C}$ at a rate of $3{ }^{\circ} \mathrm{C} \min ^{-1}$. Samples $(1 \mu \mathrm{L})$ were injected manually after a dwell-time of $c a 2$ s. Injections of each FAME were carried out in triplicate.

Qualitative fatty acid (FA) composition of the samples was determined by comparing the retention times of the peaks produced after injecting the methylated samples with those of the respective standards of FA (catalog\# 05632, 189-19; Sigma, Bellefonte, PA, USA). The quantitative composition of each FA was calculated from the area of each peak, and expressed as a percentage according to the Official Method Ce 1-62 (AOCS, 1997). The results of all samples were reported as mean values of twelve runs. Classification of fatty acids, with respect to the chain number of

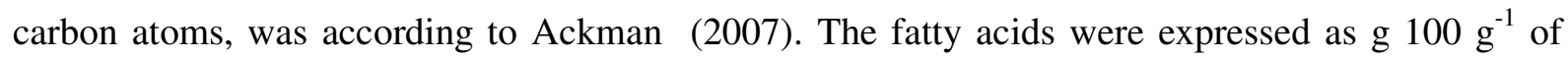
total fatty acid.

\subsubsection{Statistical analyses}

Results were analyzed by two-way ANOVA, and the effect of time and different interactions (probiotic culture, treatment - with or without açai) were assessed using a General Linear Model with Statistica Software 8.0 (Statsoft, Tulsa, OK, USA). Mean values were compared using the Tukey test at $P<0.05$. Different letters were used to label values with statistically significant differences among them.

\subsection{Results and Discussion}

\subsubsection{Fermentation time}

Addition of açai pulp to the milk before fermentation had a significant effect on $\mathrm{pH}$, reaching $6.52( \pm 0.02)$ in skimmed milk, and $6.42( \pm 0.01)$ in the sample with açai pulp $(P<0.05)$. Açai pulp caused a significant reduction $(P<0.05)$ of $\mathrm{T}_{\mathrm{pH} 4.5}$ in yogurt without probiotics and in yogurt with L. acidophilus L10, B. lactis B94 and with B. longum B105 strains compared to their control without fruit, pointing to a synergistic effect of açai pulp and lactic bacteria on total fermentation time in these cases (Figure 2.1). A shorter fermentation time $(\sim 5 \mathrm{~h}, P<0.05)$, was observed in yogurts containing Bifidobacterium animalis subsp. lactis B104 or B94 (Figure 2.1) but in these cases, açai pulp showed no effect $(P>0.05)$ on $\mathrm{T}_{\mathrm{pH} 4.5}$. 
According to Schauss et al (2006), açai pulp contains $8.1 \mathrm{~g}$ of protein, $32.5 \mathrm{~g}$ of lipids, $52.2 \mathrm{~g}$ of carbohydrates, $44.2 \mathrm{~g}$ of dietary fiber and $3.8 \mathrm{~g}$ of ash per $100 \mathrm{~g}$ of freeze-dried pulp. Donkor et al (2007) and Oliveira et al (2009) reported a lower fermentation time for probiotic yogurts supplemented with prebiotics. Therefore, the presence of açai pulp, as a prebiotic, may have positively influenced the fermentation time of L. acidophilus L10 and B. longum B105 yogurts. The mineral content of açai pulp shows high amounts of magnesium, $124.4 \mathrm{mg}$ (MENEZES et al, 2008), calcium, $260.0 \mathrm{mg}$ (SCHAUSS et al, 2006) and potassium, $900 \mathrm{mg}$ (Menezes et al, 2008), in addition to minor quantity of zinc, $6.0 \mathrm{mg}$ and iron, $15.0 \mathrm{mg}$ (SANABRIA \& SANGRONIS, 2007), manganese, $17.1 \mathrm{mg}$ and selenium, $0.02 \mathrm{mg}$ (MENEZES et al, 2008) per $100 \mathrm{~g}$ of freeze-dried pulp. Bomba et al (2002) reported that some micronutrients, such Mn, are essential for bifidobacteria and lactobacilli growth. Moreover, the incorporation of micronutrients into the milk, such as peptides and amino acids, can lead to a reduction in fermentation time (OLIVEIRA et al, 2001).

\subsection{2. $\mathrm{pH}$, titratable acidity and lactose content reduction}

At day 1, $\mathrm{pH}$ varied from 4.49 to 4.59 amongst the treatments. The açai yogurts with L. acidophilus L10 and B. animalis ssp. lactis B104 strains and without probiotic had lower $\mathrm{pH}$ $(P<0.05)$ in relation to the corresponding controls without pulp (Table 2.2). However, açai yogurt with B94 strain, YAB94, showed a significant $(P<0.05)$ increase in $\mathrm{pH}$ when compared to its control, YB94 (Table 2.2). The titratable acidity data ranged from 0.81 to $0.97 \mathrm{mg}$ lactic acid $\mathrm{g}^{-1}$. Higher levels $(P<0.05)$ of titratable acidity were observed at day 1 in açai yogurts with L. acidophilus L10, B. animalis ssp. lactis B104 and B94 strains compared to their respective control yogurts (Table 2.2).

At day 14 , açai yogurt without probiotic $(Y A)$ showed higher $(P<0.05) \mathrm{pH}$ compared to its control (Y) without pulp (Table 2.2$)$. Titratable acidity was significantly higher $(P<0.05)$ in the yogurt containing açai for the YALa yogurts when compared to the controls without fruit (YLa), (Table 2.2). On the other hand, titratable acidity was lower $(P<0.05)$ in açai yogurt without probiotic (YA) compared to its control (Y), (Table 2.2). After two weeks of cold storage, yogurts with or without açai with B. longum B105, B. animalis ssp. lactis B104 and B94 strains showed no difference $(P>0.05)$ on titratable acidity (Table 2.2$)$. 


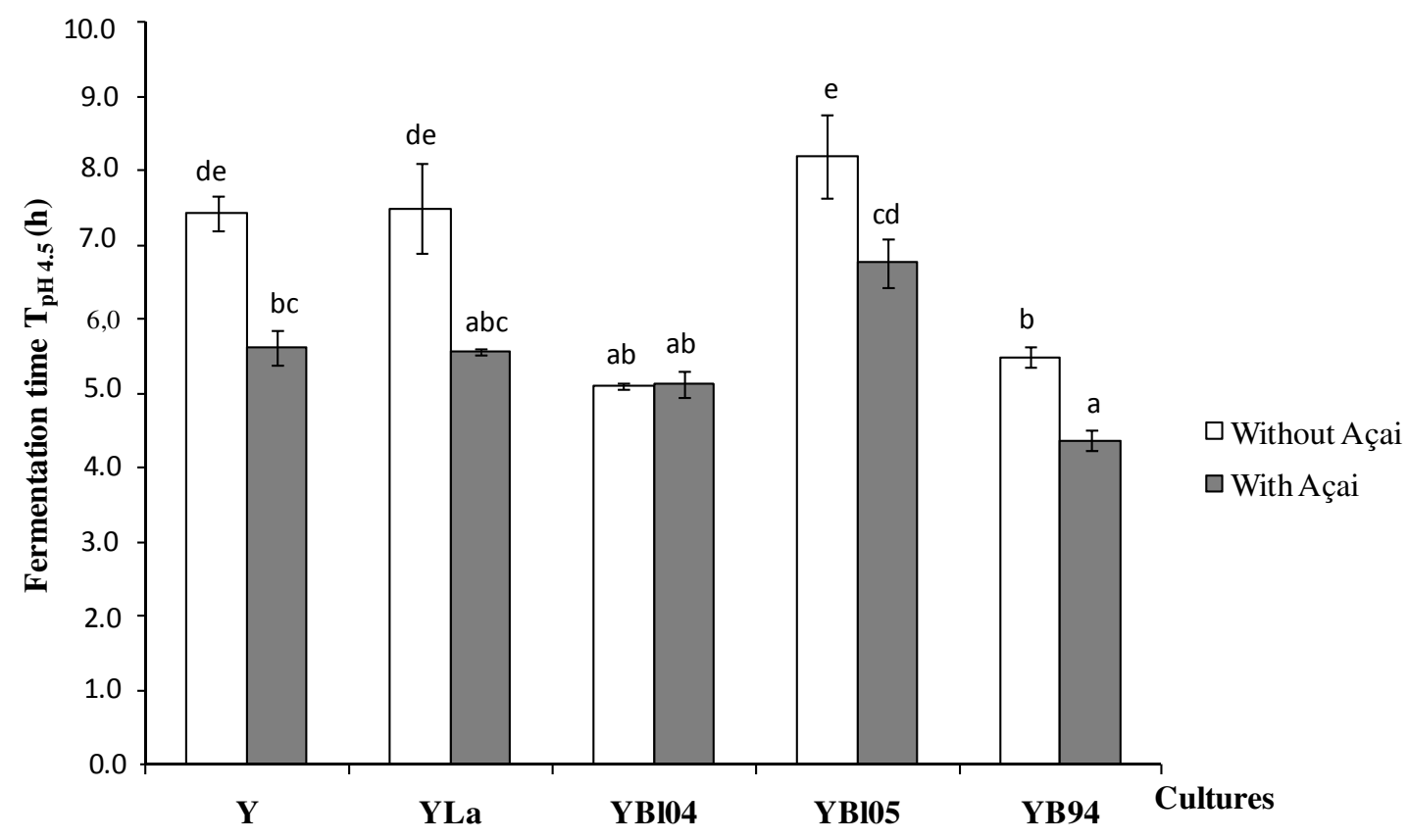

Figure 2.1. Fermentation time $\left(\mathrm{T}_{\mathrm{pH}}\right.$.5) of yogurt with and without açai pulp by starter co-cultures associated with different probiotic strains.

Abbreviations: Yogurts associated with L. acidophilus L10 (YLa), B. lactis B104 (YB104), B. longum B105 (YB105) and B. lactis B94 (YB94). Means with different letters are significantly different $(P<0.05)$. $\mathrm{N}=4$.

After 28 days of cold storage, the $\mathrm{pH}$ varied from 4.20 to 4.33 amongst the different treatments (Table 2.2). Açai yogurts containing B104 or B105 strains showed a significantly higher $\mathrm{pH}(P<0.05)$ in relation to their respective controls without fruit (Table 2.2). Nevertheless, titratable acidity varied from 0.94 to $1.08 \mathrm{mg}$ lactic acid $\mathrm{g}^{-1}$ amongst treatments and showed no difference $(P>0.05)$ due to açai presence in relation to the respective controls (Table 2.2).

Lactose content decreased after fermentation for both the original skim milk and the skim milk with açai pulp (data not shown). Lactose content of reconstituted skim milk was reduced by $18.9 \%$ by starter co-culture St-Lb CY340 and the açai yogurt showed a $16.3 \%$ decrease in lactose content by the same starter co-culture, showing a significant $(P<0.05)$ effect of fruit pulp addition. When the effects of açai and probiotic culture are considered together, açai yogurts containing $L$. acidophilus $\mathrm{L} 10$ or B. animalis ssp. lactis B104 showed the lowest lactose content reduction of $4.7 \%$ and $3.5 \%$ respectively (data not shown). 
Table 2.2. Post-acidification $(\mathrm{pH})$ and titratable acidity during shelf-life of yogurts with (YA) and without (Y) açai pulp.

\begin{tabular}{lllllll}
\hline Yogurts & \multicolumn{3}{c}{$\mathbf{p H}^{*}$} & \multicolumn{2}{c}{ Titratable acidity (\% lactic acid) } \\
\cline { 2 - 7 } & D 1 & D 14 & D 28 & D 1 & D 14 & D 28 \\
\hline Y & $4.56^{\mathrm{ef}}$ & $4.24^{\mathrm{ac}}$ & $4.25^{\mathrm{abcd}}$ & $0.85^{\mathrm{abcd}}$ & $0.99^{\mathrm{cd}}$ & $1.03^{\mathrm{bc}}$ \\
YLa & $4.58^{\mathrm{fg}}$ & $4.24^{\mathrm{abc}}$ & $4.23^{\mathrm{acd}}$ & $0.82^{\mathrm{ab}}$ & $0.94^{\mathrm{abc}}$ & $0.97^{\mathrm{ab}}$ \\
YB104 & $4.59^{\mathrm{g}}$ & $4.22^{\mathrm{c}}$ & $4.20^{\mathrm{cd}}$ & $0.84^{\mathrm{abc}}$ & $0.96^{\mathrm{bcd}}$ & $1.00^{\mathrm{abc}}$ \\
YB105 & $4.51^{\mathrm{abc}}$ & $4.31^{\mathrm{ab}}$ & $4.20^{\mathrm{c}}$ & $0.85^{\mathrm{abcd}}$ & $0.85^{\mathrm{e}}$ & $0.97^{\mathrm{ab}}$ \\
YB94 & $4.49^{\mathrm{ab}}$ & $4.27^{\mathrm{abc}}$ & $4.28^{\mathrm{abe}}$ & $0.81^{\mathrm{a}}$ & $0.81^{\mathrm{ab}}$ & $0.97^{\mathrm{ab}}$ \\
YA & $4.50^{\mathrm{a}}$ & $4.31^{\mathrm{b}}$ & $4.31^{\mathrm{be}}$ & $0.92^{\mathrm{cde}}$ & $0.92^{\mathrm{f}}$ & $1.08^{\mathrm{c}}$ \\
YALa & $4.49^{\mathrm{a}}$ & $4.30^{\mathrm{ab}}$ & $4.27^{\mathrm{abde}}$ & $0.97^{\mathrm{e}}$ & $0.97^{\mathrm{d}}$ & $1.01^{\mathrm{abc}}$ \\
YAB104 & $4.53^{\mathrm{cde}}$ & $4.27^{\mathrm{abc}}$ & $4.33^{\mathrm{e}}$ & $0.96^{\mathrm{e}}$ & $0.96^{\mathrm{d}}$ & $0.94^{\mathrm{a}}$ \\
YAB105 & $4.53^{\mathrm{bcd}}$ & $4.29^{\mathrm{abc}}$ & $4.28^{\mathrm{abe}}$ & $0.93^{\mathrm{de}}$ & $0.93^{\mathrm{ae}}$ & $0.94^{\mathrm{a}}$ \\
YAB94 & $4.55^{\mathrm{de}}$ & $4.31^{\mathrm{ab}}$ & $4.25^{\mathrm{abcd}}$ & $0.90^{\mathrm{bcde}}$ & $0.90^{\mathrm{abc}}$ & $0.96^{\mathrm{ab}}$ \\
\hline
\end{tabular}

Means $(\mathrm{N}=4)$ with different letters in the same column are significantly different $(P<0.05) .{ }^{*}$ Standard deviations were under 0.05 .

Abbreviations: YLa and YALa yogurts associated with L. acidophilus L10; YB104 and YABl04 yogurts associated with B. lactis B104; YB105 and YAB105 yogurts associated with B. longum B105; YB94 and YAB94 yogurts associated with B. lactis B94.

\subsubsection{Counts of viable microorganisms}

Inoculation rate of starter co-culture of S. thermophilus - L. delbrueckii ssp. bulgaricus CY340 and probiotic strains showed no significant difference $(P>0.05)$ among treatments (Table 2.1). S. thermophilus counts varied from 9.6 to $10.6 \mathrm{Log}_{\mathrm{CFU} \mathrm{mL}}^{-1}$ after 1 day of cold storage, and showed the highest counts $(P<0.05)$ in the yogurt with B. lactis B104 strain and açai pulp (Figure 2.2). However, on day 14 all açai yogurts showed higher $(P<0.05)$ counts of $S$. thermophilus compared to yogurt without fruit. After 4 weeks of cold storage, S. thermophilus counts were significantly $(P<0.05)$ higher in açai yogurts with L. acidophilus L10, B. lactis B104 and B94 strains (Figure 2.2). 
After 1 day of cold storage, L. delbrueckii ssp. bulgaricus exhibited poor growth and the counts varied from 3.0 to 5.9 $\mathrm{Log}_{\mathrm{CFU} \mathrm{mL}} \mathrm{mL}^{-1}$ (Figure 2.3). On day 14, açai yogurts without probiotic (YA) and açai yogurts with $B$. lactis B105 strain presented higher counts $(P<0.05)$ compared to their control without pulp. L. acidophilus L10 had the best positive effect $(P<0.05)$ on $L$. delbrueckii ssp. bulgaricus counts, which were $\sim 5.9 \mathrm{Log}_{\mathrm{CFU} \mathrm{mL}}^{-1}$ in both yogurts with or without açai on days 1 and 14 (Figure 2.3). The counts of L. delbrueckii ssp. bulgaricus on day 28 varied from 1.0 to $1.7 \mathrm{Log} \mathrm{CFU} \mathrm{mL} \mathrm{m}^{-1}$. The presence of açai pulp had a positive effect $(P<0.05)$ upon the counts of this microorganism in yogurts without probiotic and in yogurts with B. lactis B105 strain; likewise on day 14.

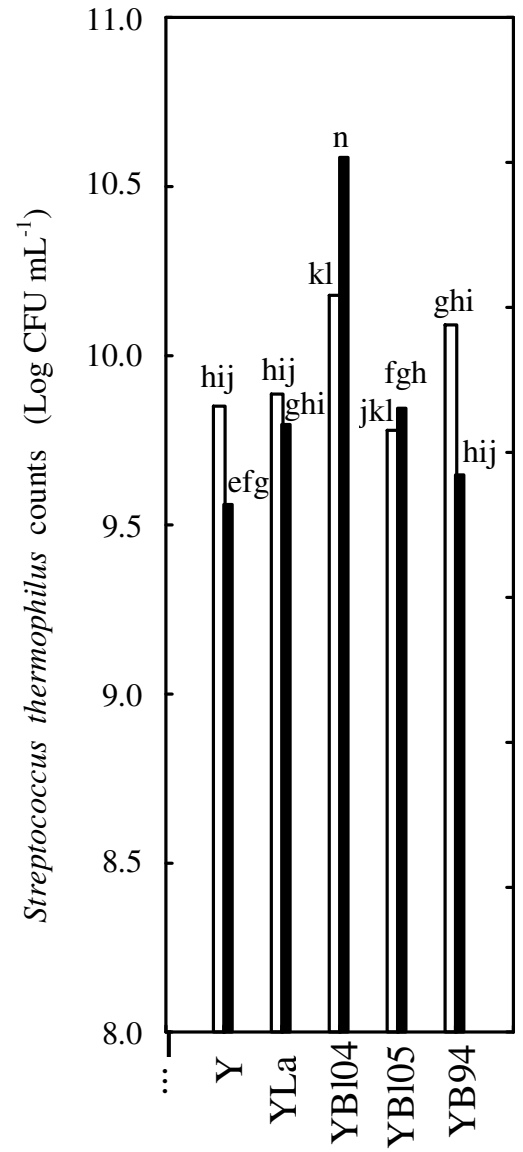

d1

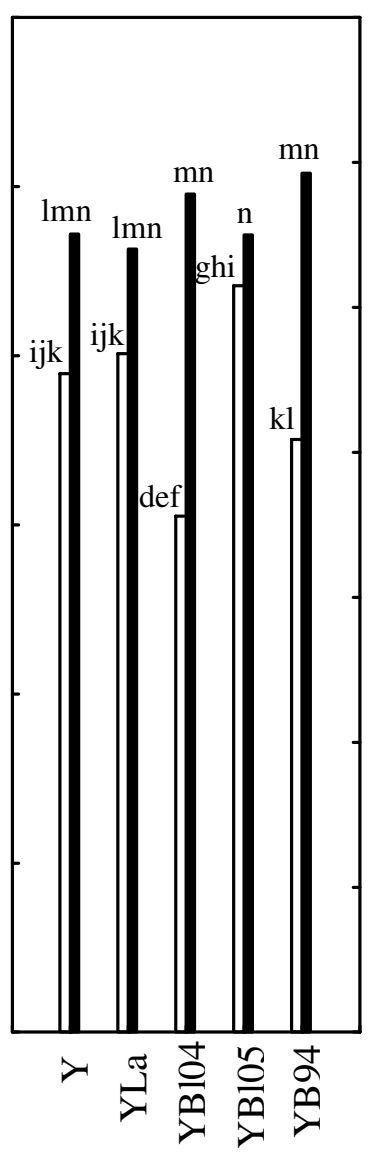

d14

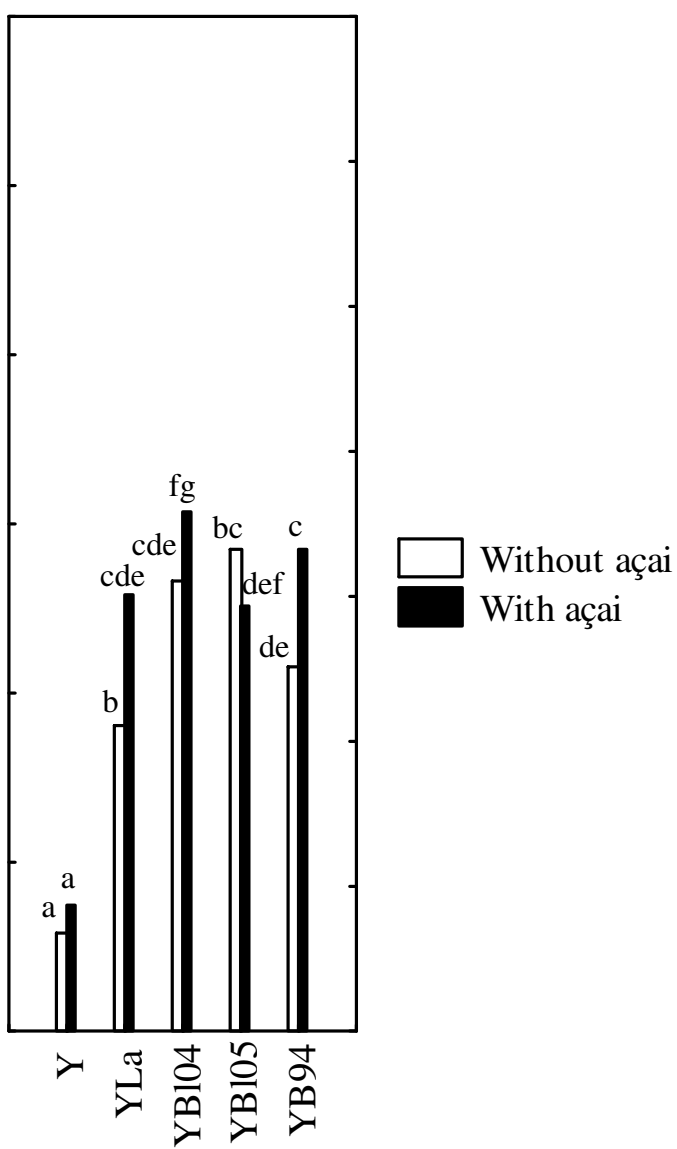

$\mathrm{d} 28$

Figure 2.2. Streptococcus thermophilus counts in yogurt with and without açai pulp during shelf-life. Abbreviations: Yogurts associated with L. acidophilus L10 (YLa), B. lactis B104 (YB104), B. longum B105 (YB105) and B. lactis B94 (YB94). Means with different letters are significantly $(P<0.05)$ different. $\mathrm{N}=40$. 


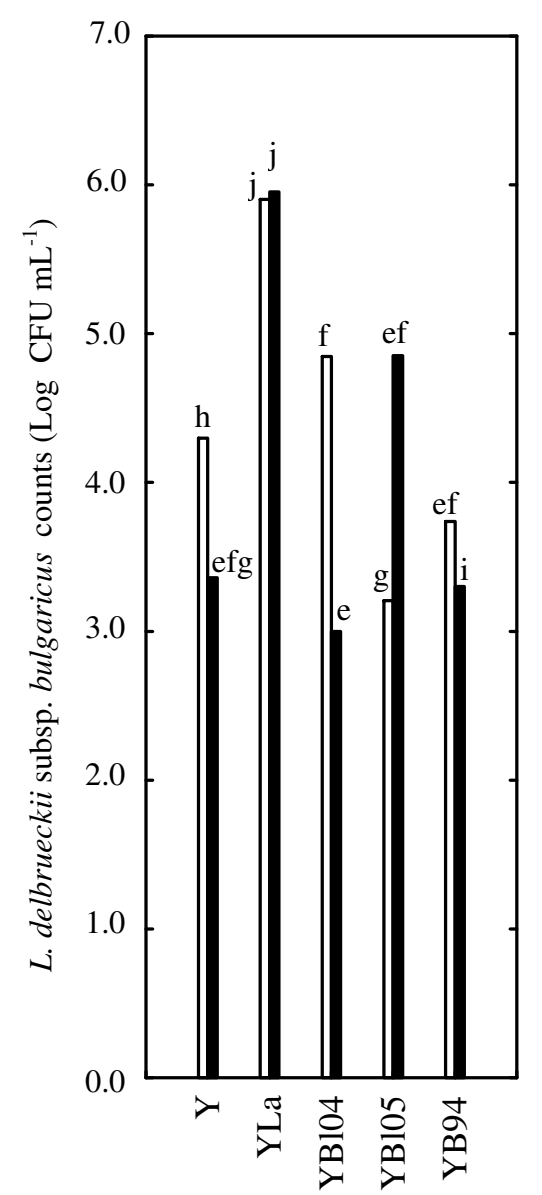

d1

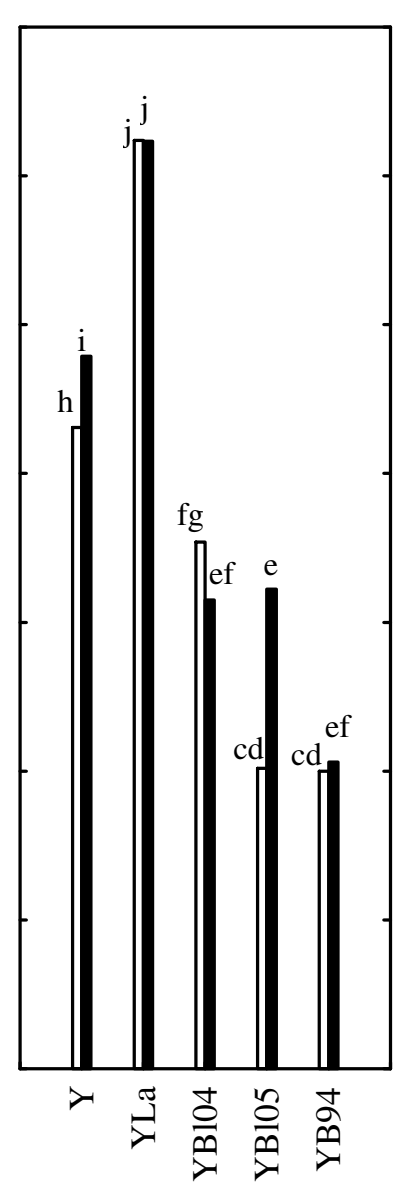

d14

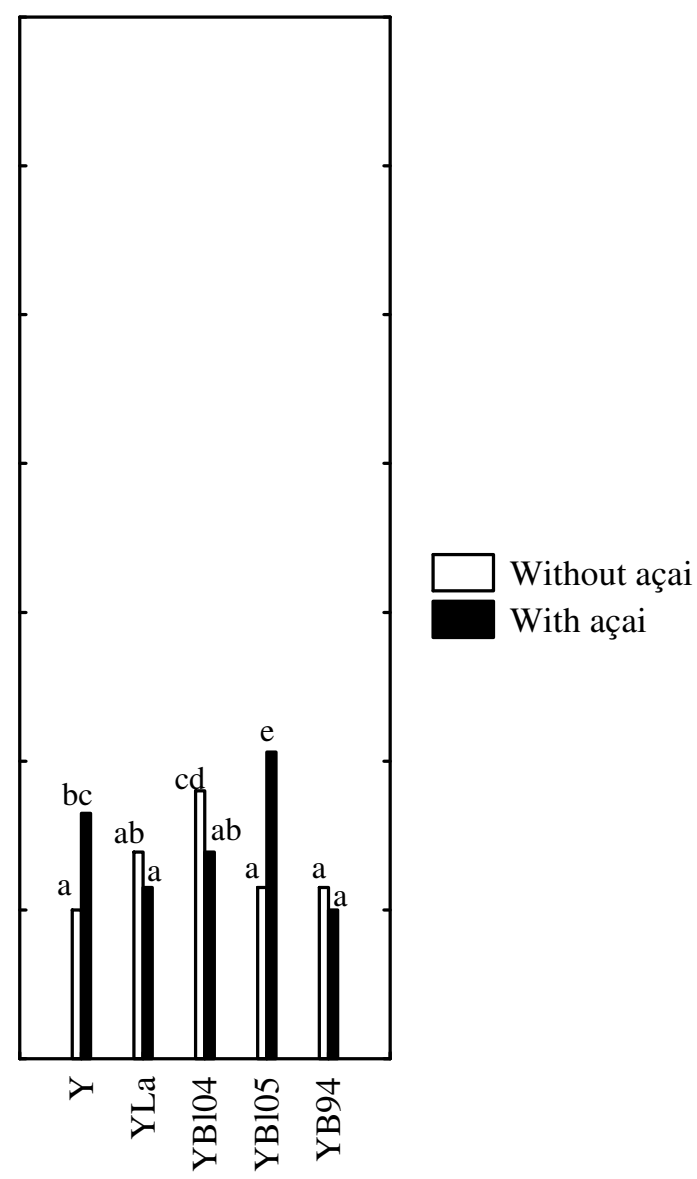

d28

Figure 2.3. Lactobacillus delbrueckii subsp. bulgaricus counts in yogurt with and without açai pulp during shelf-life. Abbreviations: Yogurts associated with L. acidophilus L10 (YLa), B. lactis B104 (YB104), B. longum B105 (YB105) and B. lactis B94 (YB94). Means with different letters are significantly $(P<0.05)$ different. $\mathrm{N}=40$. 
Probiotic counts in yogurt, with or without açai pulp, over 28 days of cold storage are shown in Figure 2.4. On day 1, the presence of açai pulp had no significant effect $(P>0.05)$ on the growth of B. lactis B104 and B94 strains, however, the presence of açai had a negative effect $(P<0.05)$ on the growth of B. longum B105 compared to the control without fruit (Figure 2.4). Furthermore, on day 1 it was observed that B. lactis (B104) counts in yogurts, with or without açai, were significantly higher $(P<0.05)$ than any other probiotic strains (Figure 2.4).

On day 14 , the L. acidophilus L10 strain in açai yogurt showed lower counts $(P<0.05)$ compared to the control without pulp, pointing to a change in the L10 strain behavior in relation to the 1st day (Figure 2.4). In the second week of cold storage, the probiotics B. lactis B104, B. lactis B94 and B. longum B105 in açai yogurt had higher counts $(P<0.05)$ compared to their respective controls without fruit (Figure 2.4). Although on day 14 B. lactis B104 and B94 had counts $\sim 8$ Log $\mathrm{CFU} \mathrm{mL}^{-1}$, B. longum $\mathrm{B} 105$ showed counts $\sim 6 \mathrm{Log} \mathrm{CFU} \mathrm{mL}^{-1}$, representing a better adaptation to the product conditions of B. lactis strains compared to B. longum (Figure 2.4). The higher count of $1 \mathrm{Log}$ CFU mL $\mathrm{mL}^{-1}$ for B94 in açai yogurt compared to its control without açai was remarkable after two weeks of cold storage (Figure 2.4). This observation has not been reported before, indicating a synergistic effect between the fruit pulp and the B. lactis B94 strain at 14 days of cold storage (Figure 2.4).

After 28 days, the enumeration of L. acidophilus L10, B. lactis B104 and B. longum B105 was higher $(P<0.05)$ in açai yogurt, i.e., 7.65, 9.36, 5.42 $\mathrm{Log} C \mathrm{CF} \mathrm{mL}^{-1}$, respectively (Figure 2.4). Between days 14 and 28, there were significant reductions $(P<0.05)$ in the B. lactis B94 and $B$. longum B105 counts in yogurts, with or without açai (Figure 2.4). The last enumeration at day 28 pointed to a lack of influence $(P>0.05)$ of açai pulp upon B94 viability. This observation indicates a probable change of synergistic behavior previously observed at 14 days of storage.

A strong variability in stability between species and strains of probiotics bacteria in fruit juices was pointed out by Champagne and Gardner (2008). Celik and Ibakirci (2003) observed that the mean count of LAB of mulberry yogurts was significantly lower than for the control. The same observation was reported by Ozturk and Oner (1999) about yogurts fermented with concentrated grape juice. However, in this study açai pulp showed no negative effect on probiotic bacteria counts after 4 weeks of cold storage (Figure 2.4). In a previous study, Almeida et al. (2008) reported the counts of L. acidophilus and B. bifidum (both Chr. Hansen, Valinhos, Brazil) at $\sim 8 \mathrm{Log}_{\mathrm{CFU}} \mathrm{mL}^{-1}$ and $7 \mathrm{Log}$ CFU mL $\mathrm{mL}^{-1}$ respectively, at day 21 of cold storage of yogurt containing açai pulp. Similar counts of L. acidophilus L10 strain were observed in the present study at day 28 of storage at $4^{\circ} \mathrm{C}$ (7.6 Log CFU mL ${ }^{-1}$ ) whereas B. animalis ssp. lactis B104 showed counts of $9.4 \mathrm{Log} C \mathrm{CU} \mathrm{mL}^{-1}$ at day 28 of cold storage, indicating improved microorganism viability compared to B. bifidum, as 
previously observed by Almeida et al. (2008). Vasiljevic and Shah (2008) reported that the recommended level of viable probiotic bacteria ranges from $6-8 \log \mathrm{CFU} \mathrm{mL} \mathrm{m}^{-1}$ at the end of cold storage, and these counts were reached by L. acidophilus L10 and B. lactis B104. However, B. longum B105 and B. lactis B94 didn't show satisfactory counts at day 28 of storage, indicating that an increase in the initial counts of the inoculum may be required.

The counts of S. thermophilus were not correlated with L. acidophilus L10 counts but showed a moderate positive correlation with B. lactis counts $(\mathrm{r}=0.5107$; Figures 2.2 and 2.4). Moreover, the $\mathrm{pH}$ showed a moderate correlation $(\mathrm{r}=0.5519)$ with the count of probiotic microorganisms. The relationship between $\mathrm{pH}$ and probiotic bacteria viability in the presence of açai pulp has not been reported before, however our results are in accordance with the observations of Kailasapathy et al. (2008) who pointed to a higher L. acidophilus L10 viability in yogurt with $\mathrm{pH}$

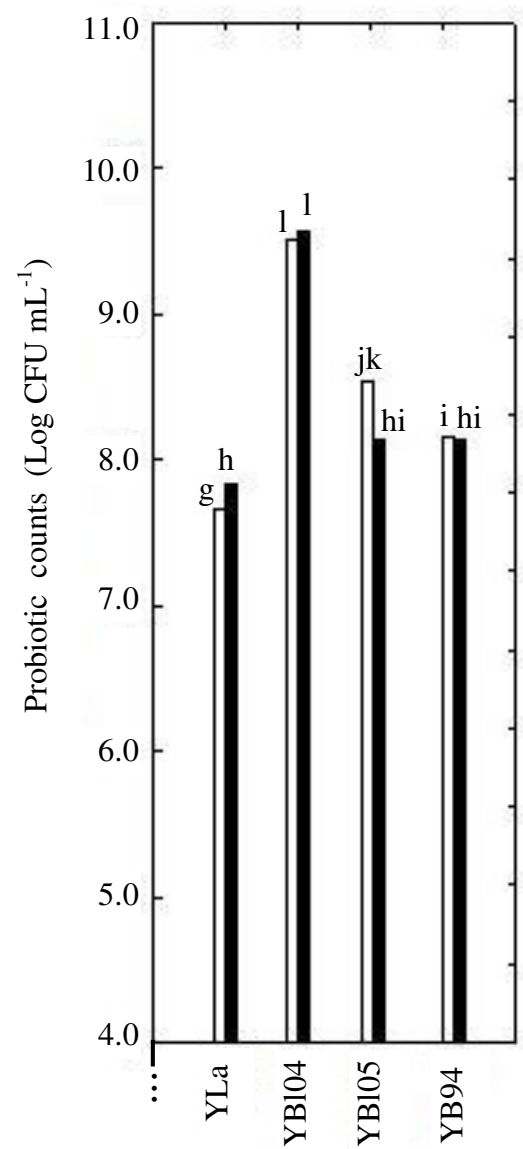

d1

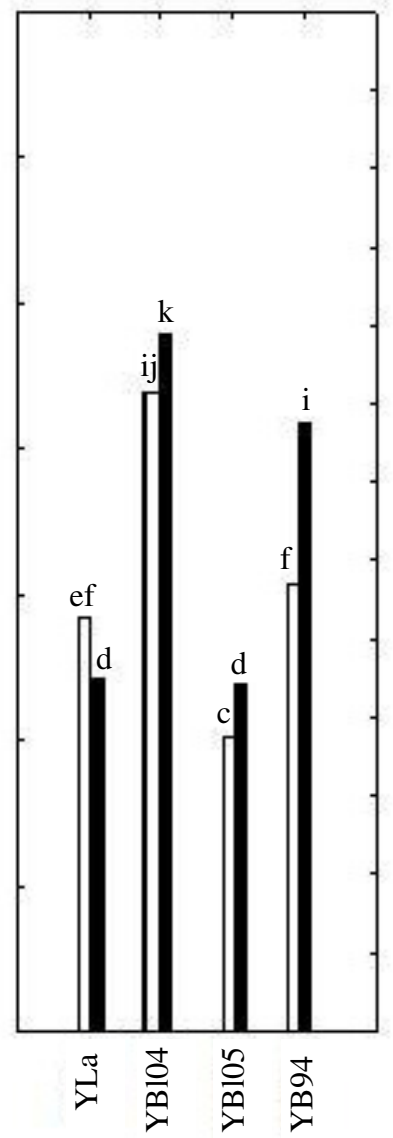

d14

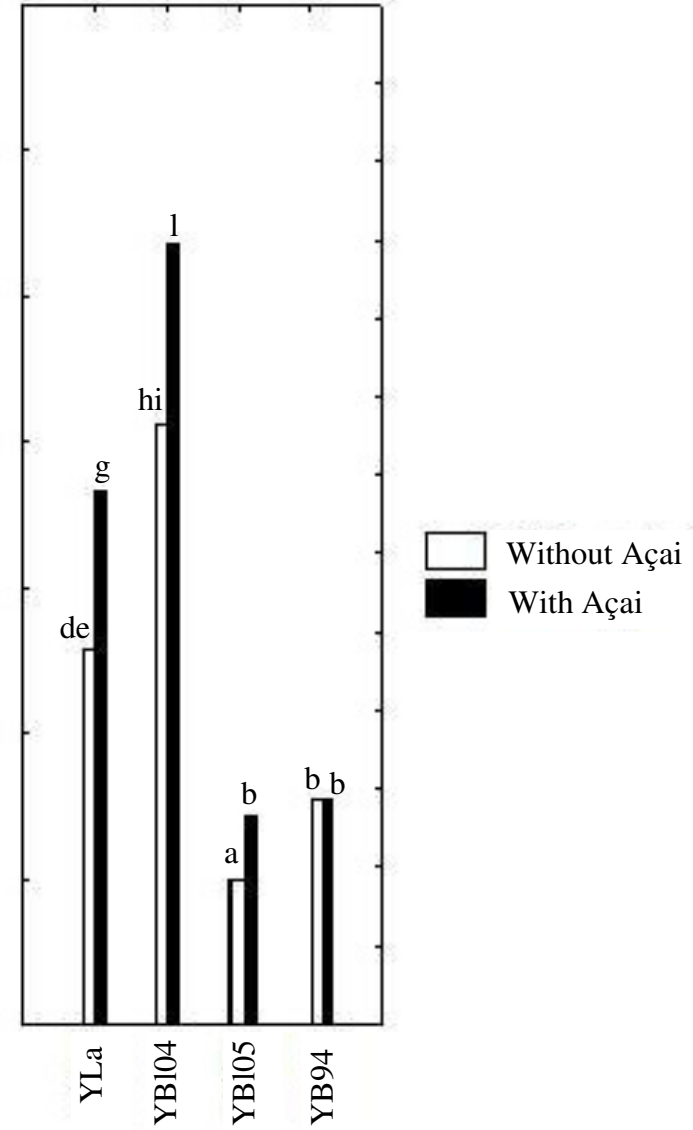

d28

Figure 2.4. Probiotic counts in yogurt with and without açai pulp during shelf-life.

Abbreviations: Yogurts associated with L. acidophilus L10 (YLa), B. lactis B104 (YB104), B. longum B105 (YB105) and B. lactis B94 (YB94). Means with different letters are significantly $(P<0.05)$ different. $\mathrm{N}=8$. 
between 4.1 and 4.5, during cold storage. Our data are also in agreement with Donkor et al. (2006) who pointed to greater $L$. acidophilus L10 and L. paracasei L26 viability in yogurt, compared to $B$. animalis ssp. lactis B94, after 28 days of cold storage. The higher counts of L. acidophilus L10 and B. lactis B104 can also be due to the higher residual lactose level of açai yogurts containing these probiotic strains (data not shown). A possible explanation for this observation could be the preference of L. acidophilus in the metabolization of sucrose which is present in açai pulp, rather than lactose (NIELSEN \& GILLILAND, 1992).

\subsubsection{Fatty acid profile}

The chromatograms of açai pulp presented the following fatty acid profile in $\mathrm{g}$ per $100 \mathrm{~g}^{-1}$ of

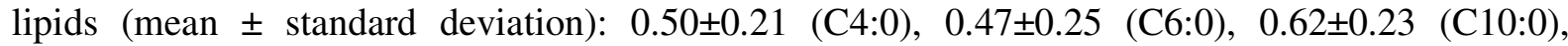

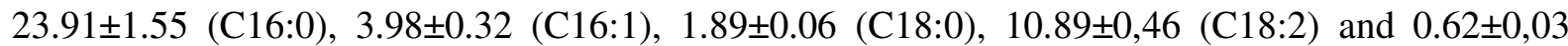
(C18:3). These values are in agreement with Nascimento et al. (2008) who report the use of açai pulp as an essential fatty acid source.

During the fermentation of milk, fatty acid profiles progressively change as a result of microbial growth (EKINCI et al., 2008). The production of free fatty acids by probiotic LAB through lipolysis of milk fat has been reported by Coskun and Ondul (2004) and Yadav et al. (2007). In the human large intestine, short-chain fatty acids (SCFA) are formed by anaerobic bacterial metabolism from carbohydrates that are not absorbed by the cells of the intestinal wall (MACFARLANE \& MACFARLANE, 2003).

The content of SCFA $(\mathrm{C} 4: 0$ and C6:0) was significantly shorter $(P<0.05)$ in açai yogurts with B. lactis B94 or L. acidophilus L10 strains compared to their controls without fruit. However, there was a reduction $(P<0.05)$ in medium-chain fatty acids (MCFA; C8:0 to C15:1) content in açai yogurt with B94 strain compared to its control without pulp (Figure 2.5). Açai increased $(P<0.05)$ the long-chain fatty acid (LCFA) content in yogurts with B. lactis B94, B. lactis B104 or L. acidophilus L10 strains compared to their controls without fruit (Figure 2.5). In yogurts without açai, it was observed that $B$. lactis B94 produced higher amounts $(P<0.05)$ of SCFA and MCFA, and lower amounts of LCFA than B. lactis B104, pointing to a strain dependent effect on fatty acid profile in this case (Figure 2.5). 


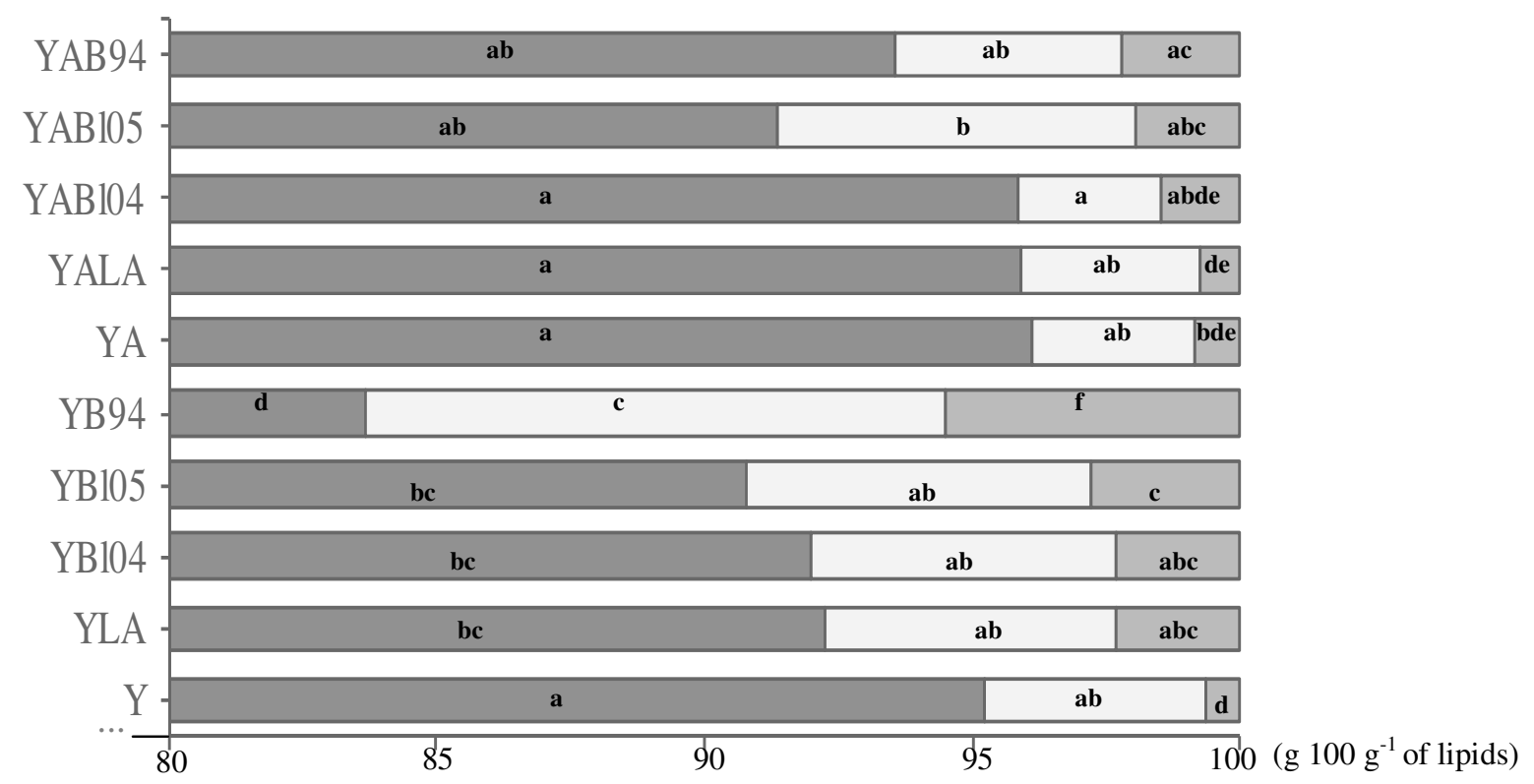

口LCFA QMCFA QSCFA

Figure 2.5. Açai (YA) and control (Y) yogurts fatty acid profile (g 100 $\mathrm{g}^{-1}$ of lipids) according to carbon chain length, observed at the day after fermentation (day 1). Means with different letters to the same carbon chain length are significantly $(P<0.05)$ different. $\mathrm{N}=12$.

Abbreviations: short chain fatty acid (SCFA, C4:0 to C6:0); medium chain fatty acid (MCFA, C8:0 to C15:1); long chain fatty acid (LCFA, C16:0 to C18:3). Yogurts associated with L. acidophilus L10 (YLa; YALa), B. lactis B104 (YB104; YAB104), B. longum B105 (YB105; YAB105) and B. lactis B94 (YB94; YAB94).

All açai yogurts showed higher content $(P<0.05)$ of monounsaturated fatty acids (MUFA) and PUFA compared to their controls without pulp (Table 2.3). On the other hand, yogurts without açai showed the highest content $(P<0.05)$ of saturated fatty acids (SFA; Table 2.3). Amongst yogurts without fruit, $B$. lactis B94 increased SFA and reduced significantly $(P<0.05)$ MUFA contents. Nevertheless, among açai yogurts those with B. longum B105 showed the higher SFA content and the lower MUFA and PUFA contents $(P<0.05$; Table 2.3). These observations suggest a strain dependent effect upon unsaturated fatty acid profile of yogurts.

Polyunsaturated fatty acids, $\omega-3$ and $\omega-6$ have been used as dietary supplements and are reported to positively affect the immune system (BOMBA et al., 2006). Besides that, PUFAs 
promote adhesion of probiotics to mucosal surfaces and alleviate changes related to allergic inflammation (KANKAANPÄA et al., 2001; DAS, 2002).

Palmitic acid $(\mathrm{C} 16: 0)$ content was significantly lower $(P<0.05)$ in açai yogurts with $B$. animalis ssp. lactis B104 and B94 strains and without probiotic (YA) compared to their respective controls without fruit $(\mathrm{Y})$. However, açai pulp contributed significantly to the increase $(P<0.05)$ in the palmitoleic acid (C16:1) content in yogurts compared to controls without pulp (Table 2.3).

Stearic acid (C18:0) content was approximately twice as high amongst control yogurts compared to açai yogurts. Moreover, açai yogurts showed higher $(P<0.05)$ contents of oleic (C18:1), linoleic (C18:2) and $\alpha$-linolenic (ALA; 18:3) acids compared to control yogurts without fruit (Table 2.3). It is important to emphasize that according to Zhao et al. (2007) a higher dietetic intake of ALA promotes reduction in lipids, lipoproteins and in the inflammatory markers Creactive protein and cell adhesion molecules, which leads to a decreased risk of cardiovascular disease. So, based on the results of the present study the consumption of açai yogurts can contribute to an increase of ALA dietary intake. 
Table 2.3. Fatty acid profile $\left(\mathrm{g} 100 \mathrm{~g}^{-1}\right)$ of yogurts without $(\mathrm{Y})$ and with (YA) açai pulp associated with different probiotic strains.

\begin{tabular}{|c|c|c|c|c|c|c|c|c|c|c|}
\hline Yogurts & SFA & MUFA & PUFA & $16: 0$ & 16:1 & 18:0 & 18:1 & $18: 2$ & CLA & ALA \\
\hline \multicolumn{11}{|l|}{ Without açai } \\
\hline $\mathbf{Y}$ & $65.77 \pm 0.11^{b}$ & $26.89 \pm 0.09^{\mathrm{a}}$ & $3.73 \pm 0.05^{\mathrm{a}}$ & $32.46 \pm 0.17^{b c}$ & $1.75 \pm 0.01^{\mathrm{a}}$ & $13.36 \pm 0.11^{\mathrm{b}}$ & $23.83 \pm 0.08^{\mathrm{a}}$ & $2.01 \pm 0.02^{\mathrm{a}}$ & $1.19 \pm 0.03^{b c d}$ & $0.53 \pm 0.01^{b}$ \\
\hline YLa & $66.86 \pm 0.36^{b}$ & $26.13 \pm 0.26^{\mathrm{a}}$ & $3.57 \pm 0.06^{\mathrm{a}}$ & $31.41 \pm 0.21^{\mathrm{bcd}}$ & $1.69 \pm 0.02^{\mathrm{a}}$ & $13.10 \pm 0.19^{b}$ & $23.18 \pm 0.29^{\mathrm{a}}$ & $1.90 \pm 0.03^{\mathrm{a}}$ & $1.16 \pm 0.01^{\mathrm{abcd}}$ & $0.51 \pm 0.02^{b}$ \\
\hline YB104 & $67.08 \pm 0.41^{\mathrm{b}}$ & $25.83 \pm 0.37^{\mathrm{a}}$ & $3.60 \pm 0.01^{\mathrm{a}}$ & $31.54 \pm 0.29^{\mathrm{bcd}}$ & $1.67 \pm 0.03^{\mathrm{a}}$ & $12.83 \pm 0.24^{b}$ & $22.88 \pm 0.40^{\mathrm{a}}$ & $1.93 \pm 0.01^{\mathrm{a}}$ & $1.17 \pm 0.03^{\mathrm{abcd}}$ & $0.51 \pm 0.03^{b}$ \\
\hline YB105 & $68.93 \pm 0.33^{\mathrm{b}}$ & $24.56 \pm 0.23^{\mathrm{a}}$ & $3.25 \pm 0.07^{\mathrm{ac}}$ & $31.73 \pm 0.58^{b c}$ & $1.71 \pm 0.05^{\mathrm{a}}$ & $11.95 \pm 0.50^{b}$ & $21.52 \pm 0.69^{a}$ & $1.78 \pm 0.05^{\mathrm{a}}$ & $1.05 \pm 0.03^{\mathrm{abe}}$ & $0.42 \pm 0.05^{b}$ \\
\hline YB94 & $91.59 \pm 0.84^{\mathrm{d}}$ & $6.24 \pm 0.56^{\mathrm{c}}$ & $2.31 \pm 0.59^{c}$ & $33.27 \pm 1.67^{\mathrm{c}}$ & $1.80 \pm 0.03^{\mathrm{a}}$ & $19.15 \pm 0.50^{\mathrm{c}}$ & $2.89 \pm 0.89^{c}$ & $1.58 \pm 0.48^{\mathrm{a}}$ & $0.88 \pm 0.06^{\mathrm{e}}$ & $0.73 \pm 0.02^{\mathrm{cd}}$ \\
\hline \multicolumn{11}{|l|}{ With açai } \\
\hline YA & $44.35 \pm 2.53^{\mathrm{a}}$ & $44.24 \pm 2.17^{\mathrm{b}}$ & $9.24 \pm 0.87^{\mathrm{b}}$ & $27.20 \pm 1.91^{\mathrm{a}}$ & $3.11 \pm 0.30^{b c}$ & $5.92 \pm 0.71^{a}$ & $40.54 \pm 3.52^{b}$ & $7.19 \pm 0.61^{c}$ & $1.16 \pm 0.08^{\mathrm{abcd}}$ & $0.88 \pm 0.18^{a}$ \\
\hline YALa & $45.55 \pm 2.60^{\mathrm{a}}$ & $43.39 \pm 1.70^{\mathrm{b}}$ & $8.90 \pm 0.54^{\mathrm{b}}$ & $28.10 \pm 1.33^{\mathrm{ad}}$ & $3.26 \pm 0.19^{b}$ & $5.64 \pm 0.37^{\mathrm{a}}$ & $39.52 \pm 1.94^{b}$ & $7.03 \pm 0.38^{b c}$ & $1.02 \pm 0.05^{\mathrm{abe}}$ & $0.85 \pm 0.11^{\mathrm{a}}$ \\
\hline YABI04 & $45.31 \pm 2.10^{\mathrm{a}}$ & $43.62 \pm 1.61^{\mathrm{b}}$ & $9.03 \pm 0.40^{\mathrm{b}}$ & $27.12 \pm 0.57^{\mathrm{a}}$ & $2.83 \pm 0.07^{\mathrm{cd}}$ & $6.87 \pm 0.24^{\mathrm{a}}$ & $40.18 \pm 1.26^{b}$ & $6.77 \pm 0.22^{b c}$ & $1.41 \pm 0.04^{\mathrm{f}}$ & $0.85 \pm 0.09^{a}$ \\
\hline YAB105 & $55.75 \pm 3.04^{\mathrm{c}}$ & $36.72 \pm 2.08^{\mathrm{d}}$ & $7.21 \pm 0.53^{\mathrm{d}}$ & $29.42 \pm 0.44^{\mathrm{abd}}$ & $3.08 \pm 0.10^{\mathrm{b}}$ & $5.11 \pm 0.51^{a}$ & $32.82 \pm 2.79^{d}$ & $5.54 \pm 0.57^{d}$ & $0.96 \pm 0.03^{\mathrm{ae}}$ & $0.71 \pm 0.10^{d}$ \\
\hline YAB94 & $49.30 \pm 2.46^{\mathrm{a}}$ & $40.87 \pm 1.61^{\mathrm{b}}$ & $8.45 \pm 0.30^{b}$ & $27.54 \pm 0.85^{\mathrm{a}}$ & $2.65 \pm 0.10^{\mathrm{d}}$ & $6.65 \pm 0.48^{\mathrm{a}}$ & $37.53 \pm 2.32^{b}$ & $6.27 \pm 0.37^{d}$ & $1.36 \pm 0.04^{\mathrm{df}}$ & $0.82 \pm 0.06^{\mathrm{a}}$ \\
\hline
\end{tabular}

Means $(\mathrm{N}=12) \pm$ standard deviation with different letters in the same column are significantly different $(P<0.05)$.

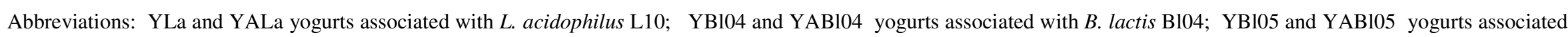

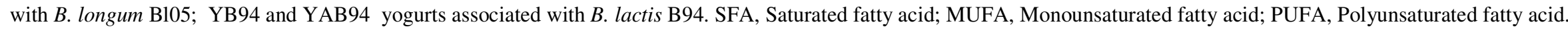
16:0, Palmitic acid; 16:1, Palmitoleic acid; 18:0, Stearic acid; 18:1, Oleic acid; 18:2, Linoleic acid; CLA, Conjugated linoleic acid (c9t11-18:2) ; ALA, $\alpha$-Linolenic acid, 18:3. 


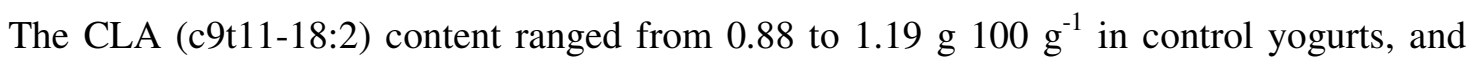

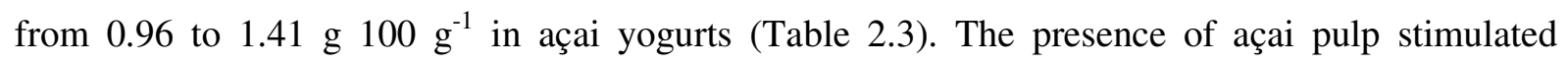
$(P<0.05)$ the CLA increase in yogurt with B. lactis B104 - around $17 \%$ higher than in yogurt without pulp (Table 2.3). Moreover, açai yogurt with B. lactis B94 showed a 35\% increase in CLA levels compared to yogurts without pulp, indicating a synergistic effect of this probiotic strain and açai pulp (Table 2.3). Sieber et al. (2004) reported that the presence of fructose increases production of c9t11-18:2 by L. delbrueckii ssp. lactis 12586. The same might have happened in the case of açai yogurts with B. lactis B104 and B94 in the present study since açai pulp is a source of fructose (SCHAUSS et al., 2006). On the other hand, CLA is an intermediate in the biohydrogenation of linoleic acid (18:2) to stearic acid by LAB (OGAWA et al., 2005). Since açai pulp is a source of linoleic acid, the açai pulp may have stimulated CLA production by B. lactis strains. This observation has not been reported before.

\subsection{Conclusions}

The addition of açai pulp into milk favored an increase in L. acidophilus L10, B. animalis ssp. lactis B104 and B. longum B105 counts at the end of 28 days of cold storage. Yogurts without açai pulp showed a greater content of saturated fatty acids whereas açai yogurts showed a higher content of polyunsaturated fatty acids. This study demonstrated that the production of bioactive lipid components such as $\alpha$-linolenic and conjugated linoleic acids can be enhanced by açai pulp addition during fermentation of skim milk prepared with B. animalis ssp. lactis B104 and B94 strains, offering potential health benefits of this probiotic açai yogurt. 


\section{CHAPTER III}

\section{Fibers from Fruit By-Products Enhance Probiotic Viability AND Fatty Acids Profile and InCRease CLA Content In Yoghurts}

\subsection{Introduction}

The waste of food is an unlucky reality worldwide (FAO/WHO, 2008). In particular, during the processing of fruit for pulp production, around $65-70 \%$ by weight of the raw material is lost, leading to serious environmental problems (LOUSADA JR et al., 2006). However, it was demonstrated that some fibers of fruit by-products show functional properties such as waterholding, swelling, gel forming, bile acid binding, and cation-exchange capacities (LAMSAL \& FAUBION, 2009). Among the promising fruit by-products are the peels of apple, banana and passion fruit, mainly because of their content of insoluble and soluble dietary fibers (DF), pectin and fructooligosaccharides. These prebiotics are in fact able to selectively stimulate the growth and activity of the gut microbiota, particularly lactobacilli and bifidobacteria (DAVIS \& MILNER, 2009).

It was reported that $100 \mathrm{~g}$ of dry apple (Malus sp., Rosaceae) by-product contain around 46 $\mathrm{g}$ of insoluble fiber, $14 \mathrm{~g}$ of soluble fiber (CHEN et al., 1988), while pectin and fructooligosaccharide account for 8-12 and $4.9 \%$ of total dietary fiber (DF), respectively NAWIRSKA \& KWASNIEWSKA, 2005). On the other hand, banana (Musa sp., Musaceae) byproduct contains around 43-49 $\mathrm{g}$ of total DF, $1 \mathrm{~g}$ of inulin, $6 \mathrm{~g}$ of fructooligosaccharide and 10-20 $\mathrm{g}$ of pectin per $100 \mathrm{~g}$ of dry matter, in addition to significant amounts of $\alpha$-linolenic acid (ALA), essential amino acids and micronutrients such as $\mathrm{Mg}, \mathrm{K}, \mathrm{P}$ and $\mathrm{Ca}$ (EMAGA et al., 2007; EMAGA et al., 2008; MOHAPATRA et al., 2010). Finally, the rind of yellow passion fruit (Passiflora edulis var. flavicarpa Degenerer, Passifloraceae) is composed of approximately $60 \mathrm{~g}$ of total insoluble dietary fiber and $20 \mathrm{~g}$ of pectin per $100 \mathrm{~g}$ of dry matter (YAPO \& KOFFI, 2008; SALGADO et al., 2010). The degrees of polymerization of homogalacturonan in apple and banana peels and in yellow passion fruit rind were found to be approximately 78, 67 and 93\%, respectively (RENARD et al., 1995; YAPO, 2009).

The dietary intake of fibers and probiotics exert a positive impact on the development of the intestinal microbiota and are reported to relieve constipation and reduce the incidence of colon 
cancer (FARNWORTH, 2008). Moreover, epidemiological investigations relate the incidence of civilization-induced diseases to insufficient DF ingestion from fruit and vegetables (NAWIRSKA \& KWASNIEWSKA, 2005). Finally, the beneficial effects on probiotics viability exerted by some ingredients such as fruit pieces or pulp to dairy foods have been reported (KOURKOUTAS et al., 2006; SENDRA et al., 2008; ESPÍRITO SANTO et al., 2010).

Some strains of bacteria are able to change the fatty acids profile of milk and produce functional fatty acids during the fermentation as the result of their growth and metabolism (COSKUN \& ONDUL, 2004; YADAV et al., 2007; EKINCI et al., 2008). Among the functional fatty acids present in the milk, the conjugated linoleic acids (CLA) stand out. It was observed that long chain polyunsaturated fatty acids such as ALA and CLA not only promote the adhesion of some Lactobacillus species to the mucosal surface of the gut, but also alleviate the symptoms associated to bowel inflammation (KANKAANPÄA et al., 2001; DAS \& FAMS, 2002). CLA present in the milk is produced as an intermediate compound in the biohydrogenation of the linoleic acid to stearic acid by the metabolism of bacteria in the rumen (KIM \& LIU, 2002). Furthermore, Oh et al. (2003) and Ogawa et al (2005) reported that more than 250 bacterial strains from 14 genera such as Enterococcus, Pediococcus, Propionibacterium, Lactobacillus and Bifidobacterium were found to produce CLA from linoleic acid.

Previous studies of our research group showed that the level of CLA can be increased by the addition of some ingredients to the milk to be fermented (OLIVEIRA et al., 2009; ESPÍRITO SANTO et al., 2010). Oliveira et al. (2009) employed polysaccharides such as maltodextrin, oligofructose and polydextrose and evaluated their influence on CLA content in milks fermented by Streptococcus thermophilus and one strain of Lactobacillus or Bifidobacterium animalis subsp. lactis. Those commercially available prebiotics are far chemically simpler ingredients than total dietary fruit fibers, such as those from apples, bananas and passion fruit, which contain soluble and insoluble fibers, others carbohydrates, phenolic compounds, proteins, minerals and vitamins (NAWIRSKA \& KWASNIEWSKA, 2005; MOHAPATRA et al., 2010 and SALGADO et al., 2010). To improve the fatty acids profile of the yoghurts fermented by $S$. thermophilus and $L$. delbrueckii subsp. bulgaricus and $\quad$ B. lactis B104 or B94 strains, Espírito Santo et al. (2010) added açai pulp to the milk thus offering an extra amount of polyunsaturated fatty acids and CLA precursors. Similarly, Xu et al. (2005) demonstrated that the addition of $0.1 \%$ linoleic acid is able to increase significantly the CLA content in yoghurts fermented by S. thermophilus and L. delbrueckii subsp. bulgaricus in co-culture with some probiotic strains, but not in yoghurts fermented by the starter culture alone. 
The addition of a complex ingredient such as fruit pulp or total dietetic fruit fiber in the formulation of a probiotic product is a challenge, mainly due to the presence of antimicrobial compounds in the fruit and its acidity (ESPÍRITO SANTO et al., 2011). The trend to use byproducts from fruits can contribute to obtain cheap, high value-added dairy products able to increase the daily intake of dietary fiber and improve the yoghurt bacteria viability (FERNANDEZGARCIA \& MCGREGOR, 1997; STAFFOLO et al., 2004; SENDRA et al., 2008). But, what is the effect of the total dietetic fruit fiber on the fatty acids profile of probiotic yoghurts? This question is still unanswered.

To contribute to fulfill this gap, the aim of this study was to evaluate the effect of the addition of the total dietetic fiber from apple, banana and passion fruit processing by-products on the fatty acids profile and counts of viable microorganisms in yoghurts co-fermented by a starter culture plus one of four different probiotic strains. Post-acidification and titratable acidity of the yoghurts were also evaluated during cold storage. The main novelty of such an approach should be recognized in its attempt to reveal in probiotic yoghurts the transformation of fatty acids profile, particularly CLA, not through the usual addition of CLA precursors or commercial soluble fibers, but through the addition of cheap total dietary fibers, by-producst of the fruit pulp industry. Compared with previous study made with açai pulp as a lipid source (ESPÍRITO SANTO et al., 2010), an additional innovating issue of this work is the use of the above three different fruit fibers to increase the viability of probiotics and to produce yoghurts with higher dietary fiber content.

\subsection{Materials and methods}

\subsubsection{Preparation of fibers}

Apple (gala cultivar), banana (cavendish cultivar) and passion fruit (yellow cultivar) byproducts were obtained from a factory of fruit pulp located in the city of Jundiai, São Paulo State, Brazil. In the factory the fruits were cleaned and pressed in a hydraulic presser at room temperature $\left(25{ }^{\circ} \mathrm{C}\right)$. The by-products were collected just after the industrial processing and frozen at $-25{ }^{\circ} \mathrm{C}$. They were transported to the laboratory as frozen material in polystyrene container the next day and stored in a bench-scale freezer, in order to avoid the attack of the organic material by contaminating microorganisms. In the next day, the peels of apple, banana and passion fruit were thawed, cleaned under running tap water and decontaminated in $5 \mathrm{ppm}$ of chlorine active hypochlorite solution for $30 \mathrm{~min}$. The material was then dried in oven with circulating air at $60{ }^{\circ} \mathrm{C}$ until constant weight. The dry peels were reduced to fine powders in a Bimby processor, model TM 31 (Vorwerk, Wuppertal, 
Germany). To make the mixture of the fiber powder with the reconstituted milk easier, the particle size was standardized to less than $17.7 \mu \mathrm{m}$ and measured through sieves (Granutest, São Paulo, Brazil) with mesh diameters of 200, 119, 59, 42 and $17.7 \mu \mathrm{m}$. The resulting fiber powders (Figure 3.1) were stored in sealed glass pots and kept under refrigeration at $4{ }^{\circ} \mathrm{C}$.
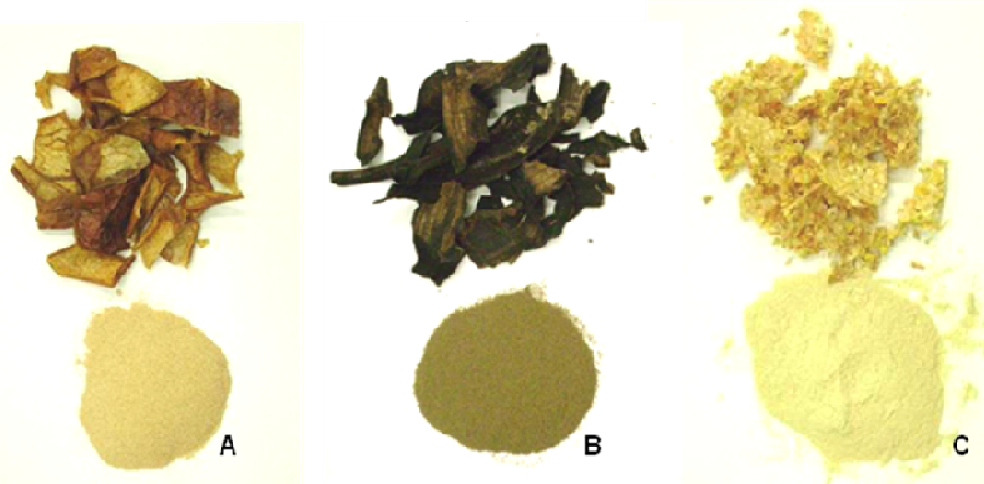

Figure 3.1: Fiber powders of apple (A), banana (B) and passion fruit (C) by-products

\subsubsection{Yoghurt manufacture}

Skim milk powder (2 g fat/L; Molico, Nestlé, Araçatuba, Brazil) was reconstituted to 12\% $(\mathrm{w} / \mathrm{w})$ in distilled water and divided into two milk bases: the one containing $1 \%$ fiber and the other without fiber (control). The milk bases were then treated thermally as described by Espírito Santo et al. (2010).

The freeze-dried starter yoghurt culture CY340 (DSM, Moorebank, NSW, Australia) was composed of Streptococcus thermophilus and Lactobacillus delbrueckii subsp. bulgaricus. It was combined with one of four probiotic cultures, specifically Lactobacillus acidophilus L10 (DSM), Bifidobacterium animalis subsp. lactis B104 and HN019 (Danisco, Madison, WI, USA), or B94 (DSM). The inocula preparation and the inoculation of milk bases were done accordingly to Espírito Santo et al. (2010). In order to make comparisons, the strains chosen for this study were the same previously investigated by our group in the preparation of others dairy fermented products (OLIVEIRA et al., 2009; ESPIRITO SANTO et al, 2010). Because in one of our previous studies the same starter co-culture (CY340) showed no pronounced effect on fatty acid profile in yoghurts (ESPIRITO SANTO et al, 2010), it was always used in combination with a probiotic strain, instead of alone. 
Sixteen different yoghurts were prepared combining 3 types of fruit fibers (plus control without fiber) with only one of the 4 probiotic strains. Two independent fermentations were performed on different days and replicated twice. After inoculation, the fermentations were carried out at $42{ }^{\circ} \mathrm{C}$ in a CINAC system (Cynetique d'acidification, Ysebaert, Frépillon, France) as described by Spinnler and Corrieu (1989). When the desired $\mathrm{pH}$ was reached $(\mathrm{pH} 4.5)$ the flasks with the yoghurts were cooled to $15{ }^{\circ} \mathrm{C}$ in ice bath, and then the clot was broken. Afterwards, the fermented milk was packed and sealed in $50 \mathrm{~mL}$ polypropylene pots and cooled to $4^{\circ} \mathrm{C}$. All sampling and analyses were performed after 1 day (d 1), 14 days (d 14) and 28 days (d 28) of cold storage at this temperature.

\subsubsection{Determination of chemical composition of fruit fibers and heat treated milk bases}

Moisture content was determined gravimetrically $\left(70 \pm 1^{\circ} \mathrm{C}\right.$ for $6 \mathrm{~h}$ in a vacuum oven) using 4-5 g of sample. Lipids, protein and ash were analyzed according to AACC (2000) methods 30-25, 46-13 and 08-01, respectively. Total dietary fiber was determined using the 985.29 AOAC (1999) method. The measurements were done in triplicate.

\subsubsection{Post-acidification and titratable acidity}

Four pots of each treatment were taken and homogenized before analyses. The yoghurt postacidification was determined as $\mathrm{pH}$ after 1,14 and 28 days using a $\mathrm{pH}$ meter, model Q-400M1 (Quimis, São Paulo, Brazil). The titratable acidity was analyzed according to recommendations of AOAC (1995). The results were expressed as the means of four replicates.

\subsubsection{Microbiological analyses}

Bacterial counts of each treatment were carried out in quadruplicate after 1, 14 and 28 days. Samples $(1 \mathrm{~mL})$ were diluted with $0.1 \%$ sterile peptonated water $(9 \mathrm{~mL})$. Afterwards, serial dilutions were carried out, and bacteria were counted, applying the pour plate technique (KODAKA et al., 2005). All media were obtained from Oxoid (Basingstoke, UK). In co-cultures, $S$. thermophilus colonies were enumerated in M17 agar, whereas those of L. delbrueckii subsp. bulgaricus were counted in MRS agar (pH 5.4), both under aerobic incubation at $37{ }^{\circ} \mathrm{C}$ for $48 \mathrm{~h}$. Enumerations of L. acidophilus were carried out in MRS agar (pH 6.2) plus $10 \mu \mathrm{L} \mathrm{mL} \mathrm{m}^{-1}$ clindamycin (Sigma, St. Louis, MO, USA), and those of B. lactis B04, B94 and HN019 in 
Reinforced Clostridial Agar plus $100 \mu \mathrm{L} \mathrm{mL}^{-1}$ of dicloxacillin (Sigma). The media M17 and MRS agar ( $\mathrm{pH}$ 5.4) were prepared according to Jordano et al. (1992) and Dave and Shah (1996). The media MRS agar ( $\mathrm{pH}$ 6.2) plus clindamycin was prepared as described by Tharmaraj and Shah (2003) and Saccaro et al. (2009). All probiotic microorganisms were incubated under anaerobic conditions, provided by AnaeroGen (Oxoid), at $37{ }^{\circ} \mathrm{C}$ for $72 \mathrm{~h}$. Cell concentration was expressed as $\log \mathrm{CFU} \mathrm{mL}^{-1}$ of yoghurt.

\subsubsection{Fatty acid profiles}

The fatty acid profile of yoghurts was determined 1, 14 and 28 days after cold storage according to the method of AOCS (1997). Four pots of each type of yoghurt were taken and homogenized before the cold extraction of the lipid fraction. The result of each treatment was reported as mean value of twelve runs.

\subsubsection{Statistical analyses}

The Statistica Software 8.0 (Statsoft, Tulsa, OK, USA) was used in all statistical analyses. The data were analyzed by two way ANOVA using Tukey test at $P<0.05$ to compare mean values, and the General Linear Model was applied to evaluate the effect of time and different interactions such as probiotic culture and fiber type. Statistically significant differences were indicated by labeling the mean values with different letters.

\subsection{Results and Discussion}

\subsubsection{Chemical composition of fruit fibers and milk bases}

The chemical composition of the total dietary fibers and the heat treated milk bases are shown in Table 3.1. In general, the chemical composition of apple, banana and passion fruit fibers are in accordance with the results of Nawirska and Kwasniewska (2005), Mohapatra et al. (2010) and Salgado et al. (2010), respectively. As expected, the addition of fiber increased by $1 \mathrm{~g} / 100 \mathrm{~g}$ the total solids (total weight - moisture) of the heat treated milk bases. 
Table 3.1. Chemical composition in $\mathrm{g} / 100 \mathrm{~g}$ of the total dietetic fibers and the heat treated skim milk bases.

\begin{tabular}{llllllll}
\hline \multicolumn{5}{c}{ Total dietetic fibers } & \multicolumn{5}{c}{ Skim milk bases } \\
\hline \multirow{3}{*}{ Proteins } & Apple & Banana & Passion fruit & Control & Apple & Banana & Passion fruit \\
Lipids & $5.21 \pm 0.02$ & $10.01 \pm 0.04$ & $6.32 \pm 0.01$ & $6.14 \pm 0.02$ & $6.19 \pm 0.02$ & $6.29 \pm 0.02$ & $6.20 \pm 0.02$ \\
Carbohydrates & $5.03 \pm 0.01$ & $8.15 \pm 0.02$ & $6.96 \pm 0.01$ & $0.20 \pm 0.00$ & $0.25 \pm 0.01$ & $0.29 \pm 0.01$ & $0.27 \pm 0.01$ \\
Ash & $78.01 \pm 0.88$ & $63.06 \pm 0.69$ & $74.33 \pm 0.75$ & $6.34 \pm 0.02$ & $7.16 \pm 0.03$ & $6.87 \pm 0.02$ & $7.02 \pm 0.02$ \\
Moisture & $2.17 \pm 0.01$ & $10.59 \pm 0.02$ & $3.88 \pm 0.02$ & $0.70 \pm 0.01$ & $0.72 \pm 0.01$ & $0.81 \pm 0.01$ & $0.74 \pm 0.01$ \\
Total dietary & $9.05 \pm 0.46$ & $8.12 \pm 0.37$ & $9.40 \pm 0.44$ & $86.57 \pm 0.55$ & $85.68 \pm 0.61$ & $85.47 \pm 0.59$ & $85.27 \pm 0.47$ \\
fiber & & & & & & & \\
\hline$N=3$ & $63.27 \pm 0.51$ & $51.19 \pm 0.43$ & $65.08 \pm 0.56$ & $0.00 \pm 0.00$ & $0.61 \pm 0.02$ & $0.52 \pm 0.00$ & $0.64 \pm 0.01$ \\
\hline
\end{tabular}

\subsubsection{Post-acidification and total titratable acidity}

The addition of fruit fiber promoted a statistically significant $(P<0.05 ; N=64)$ reduction in the initial $\mathrm{pH}$ of all heat-treated skim milk bases, specifically from 6.53 in control milk to 6.42 in milks supplemented with apple and banana fibers and to 6.30 in that supplemented with passion fruit fiber (results not shown).

After 1 day of cold storage, only the passion fruit fiber yoghurt co-fermented by Lactobacillus acidophilus L10 showed a pH significantly lower $(P<0.05)$ than its control without fiber (Table 3.2), whereas no statistically significant effect $(P>0.05)$ on post-acidification could be ascribed to the other fiber-probiotic combinations. The fibers of banana and passion fruit significantly increased $(P<0.05)$ the titratable acidity of yoghurt co-fermented by $L$ acidophilus L10 compared to the control. The same was observed with all the fibers using Bifidobacterium animalis subsp. lactis HN019 and only with the banana fiber using B. animalis subsp. lactis B104.

At the end of four weeks of shelf life (28 days), the post-acidification exhibited almost the same results as those of $\mathrm{d} 14(P<0.05)$ in Table 3.2. A slight increase of $\mathrm{pH}(P<0.05)$ was observed in yoghurts supplemented with apple and banana fibers and co-fermented by $B$. animalis subsp. lactis B104 compared to the controls. Similarly, Espírito Santo et al. (2010) reported that the $\mathrm{pH}$ of açai yoghurts fermented by the B104 strain was significantly higher $(P<0.05)$ than that of their respective controls without fruit, which indicates that the B104 strain in the presence of some fruity products may reduce its organic acid production. Regarding the control and passion fruit fiber yoghurts, it is noteworthy that the higher $\mathrm{pH}$ shown in $\mathrm{B} 104$ fermented apple and banana fibers 
yoghurts at 1 day is positively correlated $(r=0.855)$ with the high counts of this bacterium, which indicates a possible synergism between fruit fiber and probiotic via acidity regulation. On the other hand, no significant differences in $\mathrm{pH}$ due to fiber addition $(P>0.05)$ were observed in the present study in yoghurts co-fermented by the other probiotics.

Table 3.2. Post-acidification $(\mathrm{pH})$ and titratable acidity of yoghurts with and without fibers during 4 weeks of cold storage.

\begin{tabular}{lllllll}
\hline & \multicolumn{3}{c}{$\mathrm{pH}$} & \multicolumn{3}{l}{ Titratable acidity (\% lactic acid) } \\
\cline { 2 - 7 } Yoghurt & $\mathrm{d} \mathrm{1}$ & $\mathrm{d} \mathrm{14}$ & $\mathrm{d} 28$ & $\mathrm{~d} 1$ & $\mathrm{~d} 14$ & $\mathrm{~d} 28$ \\
\hline CL10 & $4.42^{\mathrm{c}}$ & $4.29^{\mathrm{ef}}$ & $4.30^{\mathrm{de}}$ & $0.81^{\mathrm{ab}}$ & $0.94^{\mathrm{cd}}$ & $0.99^{\mathrm{a}}$ \\
AL10 & $4.40^{\mathrm{abc}}$ & $4.31^{\mathrm{ef}}$ & $4.31^{\mathrm{bcd}}$ & $0.82^{\mathrm{abc}}$ & $0.99^{\mathrm{efg}}$ & $1.06^{\mathrm{abcd}}$ \\
BL10 & $4.39^{\mathrm{abc}}$ & $4.33^{\mathrm{f}}$ & $4.34^{\mathrm{e}}$ & $0.86^{\mathrm{cd}}$ & $0.91^{\mathrm{abcd}}$ & $1.04^{\mathrm{abcd}}$ \\
PL10 & $4.36^{\mathrm{a}}$ & $4.31^{\mathrm{ef}}$ & $4.32^{\mathrm{cde}}$ & $0.86^{\mathrm{cd}}$ & $0.88^{\mathrm{a}}$ & $0.99^{\mathrm{a}}$ \\
CB104 & $4.44^{\mathrm{abc}}$ & $4.22^{\mathrm{a}}$ & $4.23^{\mathrm{a}}$ & $0.86^{\mathrm{cd}}$ & $0.91^{\mathrm{abcd}}$ & $1.02^{\mathrm{abc}}$ \\
AB104 & $4.44^{\mathrm{bc}}$ & $4.28^{\mathrm{de}}$ & $4.29^{\mathrm{bcd}}$ & $0.93^{\mathrm{e}}$ & $0.96^{\mathrm{de}}$ & $1.05^{\mathrm{abcd}}$ \\
BB104 & $4.41^{\mathrm{abc}}$ & $4.27^{\mathrm{de}}$ & $4.29^{\mathrm{cde}}$ & $1.04^{\mathrm{f}}$ & $0.99^{\mathrm{ef}}$ & $1.11^{\mathrm{cd}}$ \\
PB104 & $4.41^{\mathrm{abc}}$ & $4.24^{\mathrm{ab}}$ & $4.25^{\mathrm{bc}}$ & $0.96^{\mathrm{e}}$ & $0.91^{\mathrm{abcd}}$ & $1.07^{\mathrm{abcd}}$ \\
CHN019 & $4.43^{\mathrm{abc}}$ & $4.25^{\mathrm{ab}}$ & $4.25^{\mathrm{ab}}$ & $0.87^{\mathrm{d}}$ & $0.88^{\mathrm{ab}}$ & $1.01^{\mathrm{ab}}$ \\
AHN019 & $4.41^{\mathrm{bc}}$ & $4.28^{\mathrm{bcd}}$ & $4.27^{\mathrm{bcd}}$ & $0.93^{\mathrm{e}}$ & $0.94^{\mathrm{cd}}$ & $1.07^{\mathrm{abcd}}$ \\
BHN019 & $4.38^{\mathrm{abc}}$ & $4.27^{\mathrm{bcd}}$ & $4.25^{\mathrm{bcd}}$ & $0.95^{\mathrm{e}}$ & $1.03^{\mathrm{fg}}$ & $1.04^{\mathrm{abcd}}$ \\
PHN019 & $4.40^{\mathrm{ab}}$ & $4.25^{\mathrm{bc}}$ & $4.25^{\mathrm{ab}}$ & $0.97^{\mathrm{e}}$ & $1.04^{\mathrm{g}}$ & $1.12^{\mathrm{d}}$ \\
CB94 & $4.43^{\mathrm{abc}}$ & $4.25^{\mathrm{bc}}$ & $4.25^{\mathrm{abc}}$ & $0.82^{\mathrm{abc}}$ & $0.90^{\mathrm{abc}}$ & $1.04^{\mathrm{abcd}}$ \\
AB94 & $4.40^{\mathrm{abc}}$ & $4.28^{\mathrm{bc}}$ & $4.28^{\mathrm{abc}}$ & $0.85^{\mathrm{bcd}}$ & $0.90^{\mathrm{abc}}$ & $1.03^{\mathrm{abc}}$ \\
BB94 & $4.38^{\mathrm{abc}}$ & $4.27^{\mathrm{bc}}$ & $4.28^{\mathrm{bcde}}$ & $0.78^{\mathrm{a}}$ & $0.93^{\mathrm{bcd}}$ & $1.07^{\mathrm{abcd}}$ \\
PB94 & $4.42^{\mathrm{abc}}$ & $4.28^{\mathrm{ab}}$ & $4.29^{\mathrm{ab}}$ & $0.85^{\mathrm{bcd}}$ & $0.93^{\mathrm{bcd}}$ & $1.09^{\mathrm{bcd}}$ \\
\hline
\end{tabular}

Means with different letters in the same column are significantly different $(P<0.05), N=64$. Standard deviations were lower than 0.05 and are not shown.

Abbreviations: d1, d14 and d28 mean shelf-lives of 1, 14 and 28 days. Yoghurts co-fermented by L. acidophilus L10: control (CLa), with apple fiber (ALa), with banana fiber (BLa), with passion fruit fiber (PLa). Yoghurts co-fermented by B. animalis subsp. lactis B104: control (CB104), with apple fiber (AB104), with banana fiber (BB104), with passion fruit fiber (PB104). Yoghurts co-fermented by B. animalis subsp. lactis B94: control (CB94), with apple fiber (AB94), with banana fiber (BB94), with passion fruit fiber (PB94). Yoghurts co-fermented by B. animalis subsp. lactis HN019: control (CHN019), with apple fiber (AHN019), with banana fiber (BHN019), with passion fruit fiber (P HN019). 
The same trend was observed by Staffolo et al. (2004) for yoghurts supplemented with commercial dietary fibers (apple, wheat, bamboo or inulin) without probiotics and by Sendra et al. (2008) for citrus fiber yoghurts fermented by different strains of L. acidophilus, Lactobacillus casei and Bifidobacterium bifidum during cold storage. The titration acidity increased at d 14 and kept almost the same at d 28, and the only significant effect in this sense $(P<0.05)$ was that of the passion fruit fiber with the HN019 strain. On the other hand, the yoghurts co-fermented by L. acidophilus L10 exhibited the lowest acidity values $(P<0.05)$.

\subsubsection{Viable counts}

The inoculum levels of starter culture and probiotic strains did not show any significant difference $(P>0.05)$ among the fermentations, being $7.85 \pm 0.36 \mathrm{Log}_{\mathrm{CFU} \mathrm{mL}}{ }^{-1}$ for Streptococcus thermophilus, $4.23 \pm 0.23 \mathrm{Log} \mathrm{CFU} \mathrm{mL} \mathrm{m}^{-1}$ for Lactobacillus delbrueckii subsp. bulgaricus and 7.75 $\pm 0.87 \mathrm{Log}$ CFU mL $\mathrm{m}^{-1}$ for probiotics.

Although Vinderola et al. (2002) pointed out the inhibition of S. thermophilus growth by some fruit juices, after $\mathrm{d} 1$ the counts of $S$. thermophilus (10.1-11.2 Log CFU mL $\mathrm{mL}^{-1}$ ) in apple and banana fibers yoghurts co-fermented by B. animalis subsp. lactis B104 and HN019 were significantly higher than in the controls $(P<0.05)$ (Figure 3.2). Oppositely, after d $28 S$. thermophilus counts decreased to 9.3-10.5 $\mathrm{Log} \mathrm{CFU} \mathrm{mL} \mathrm{m}^{-1}$ and were higher $(P<0.05, \mathrm{r}=0.652)$ in yoghurts co-fermented by B. animalis subsp. lactis B94 or by L. acidophilus L10. Similar results recently reported by Espírito Santo et al. (2010), who also observed higher counts of $S$. thermophilus in yoghurts co-fermented by L. acidophilus L10 and B. animalis subsp. lactis B94, reinforce the positive correlation between $S$. thermophilus and these two probiotic strains. The apparent paradox of a decrease in S. thermophilus counts after d 14 and an increase after d 28 is a fact that, indeed, frequently occurs in studies that employ commercial cultures of bacteria, especially those employed in yoghurt making (FLORENCE et al., 2009; MARAFON et al., 2011), likely because of the presence of a bouquet of bacteria with slight peculiarities in the ability of growth and survive under different conditions of the media. Being so, that group of bacteria grown under the initial conditions and survived likely became old and less adapted to the subsequent changes in $\mathrm{pH}$, acidity and nutrients. Thus, another bacteria group, adapted to the new conditions, grew, survived and became the dominant one.

After d 1, the counts of L. delbrueckii subsp. bulgaricus (5.0-9.2 Log CFU mL ${ }^{-1}$ ) were higher in yoghurts co-fermented by L. acidophilus L10 $(P<0.05)$ regardless of the presence of fibers and after the intermediate storage period ( $\mathrm{d}$ 14); therefore, it is evident that the fibers 
supplementation favored its viability. However, after d 28 the highest counts of L. delbrueckii subsp. bulgaricus were detected in yoghurts co-fermented by L. acidophilus L10, regardless of the presence of fibers (Figure 3.3). The same behavior was previously observed in yoghurts inoculated with the same microorganisms, which confirms the positive effect of L. acidophilus L10 on L. delbrueckii subsp. bulgaricus viability (Espírito Santo et al., 2010). Never the addition of fruit fiber at $1 \%$ had inhibitory effect on the viability of L. delbrueckii subsp. bulgaricus, and, in some cases as in yoghurts co-fermented by the B. animalis subsp. lactis HN019, the presence of apple and banana fibers even stimulated to cell growth compared to control yoghurts after 4 weeks of shelflife. A symbiotic effect between apple or banana fiber and B. lactis HN019 could have been responsible for the enhanced viability of $L$. delbrueckii subsp. bulgaricus. Besides, the low counts of this last microorganism during cold storage was also reported by Marafon et al. (2011), who utilized the same starter co-culture (CY340). This observation in two different and independent studies can suggest that the behavior of $L$. delbrueckii subsp. bulgaricus is intrinsic to the commercial co-culture characteristics, exhibiting lower counts compared to S. thermophilus, maybe as a way to minimize the acetic acid taste produced as the result of L. delbrueckii subsp. bulgaricus metabolism (SHENE \& BRAVO, 2007).

With regard to the probiotic counts, after d 1 both apple and banana fiber yoghurts cofermented by L. acidophilus L10 and the apple fiber one co-fermented by B. animalis subsp. lactis B94 showed counts $(11.5-11.8$ Log CFU mL-1) significantly higher than the others $(P<0.05)$, whereas the passion fruit fiber did not exert any significant effect $(P>0.05)$ on probiotic counts (10.6-11.2 Log CFU mL-1) compared to their respective controls (Figure 3.4). After d 14, no significant differences were observed in bifidobacteria counts compared to the controls (Figure 3.4), while a synergistic effect between banana fiber and $L$. acidophilus L10 is evident $(P<0.05)$. Although the longest shelf life (d 28) had a negative impact on the counts of all microorganisms, L. acidophilus L10 exhibited by far the lowest values (6.7 to 8.3 Log CFU mL-1), thus suggesting a poor resistance of this strain to the storage conditions. This observation is in accordance with the results of Lamsal and Faubion (2009), who reported lower counts of L. acidophilus than of other probiotics in oat enriched products due to its high requirements for several nutrients, whereas Donkor et al. (2006) observed a significant decrease of B. animalis subsp. lactis B94 compared to L. acidophilus L10. But the most important observation is that apple and banana fibers increased the counts of all probiotics by no less than 1 Log CFU mL-1 compared to both controls and to passion fruit fiber yoghurts, especially at d 28 (Figure 3.4). 

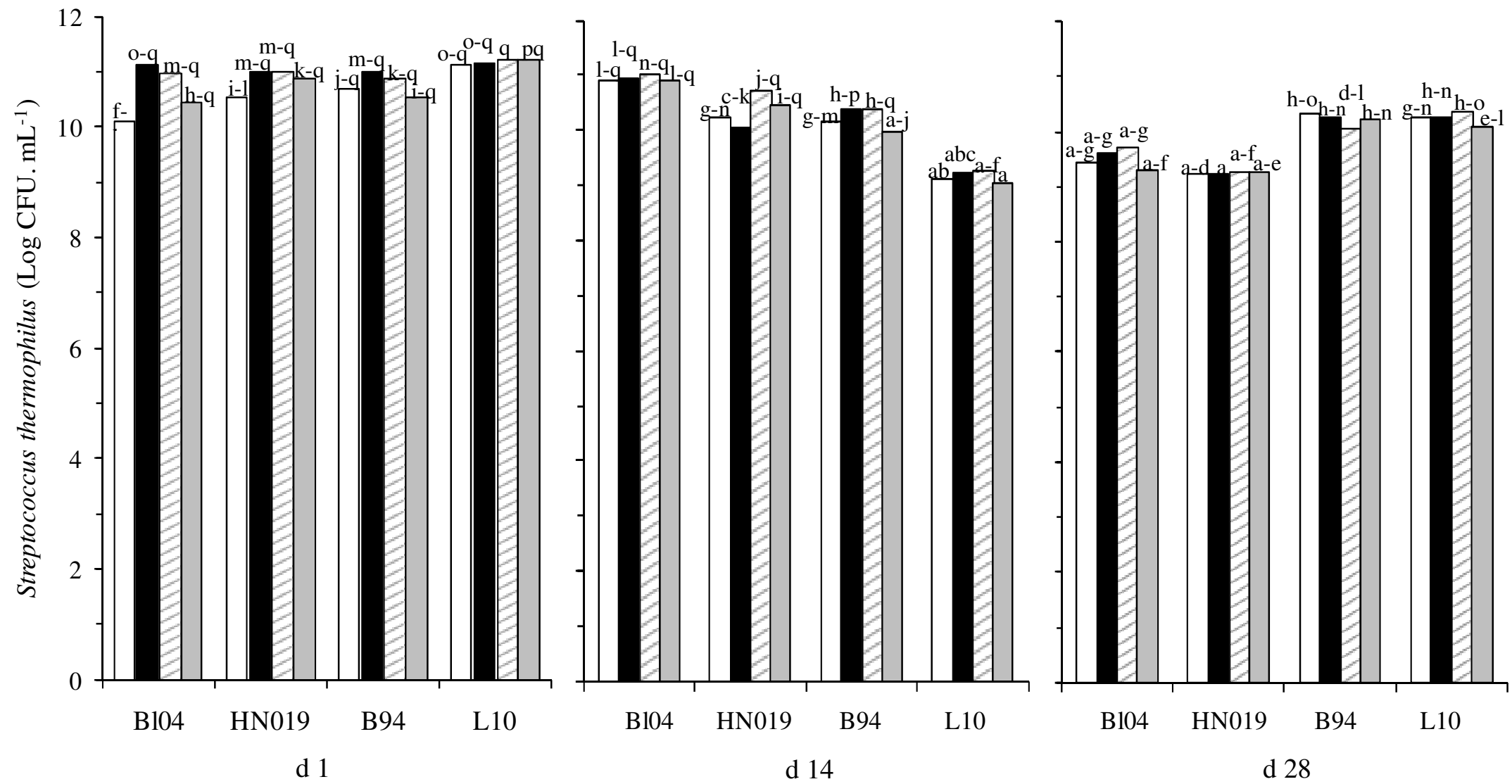

口Control

- Apple fiber

घBanana fiber

口Passion fruit fiber

Figure 3.2. Streptococcus thermophilus counts in control and fiber yoghurts co-fermented by different probiotic strains.

Abbreviations: B104, HN019, B94 = yoghurts co-fermented by B. animalis subsp. lactis B104, HN019 and B94, respectively; L10 = yoghurts co-fermented by L. acidophilus L10. Means with different letters are significantly different $(P<0.05) . N=40 . \mathrm{d} 1, \mathrm{~d} 14$ and d $28=1,14$ and 28 days of cold storage. 


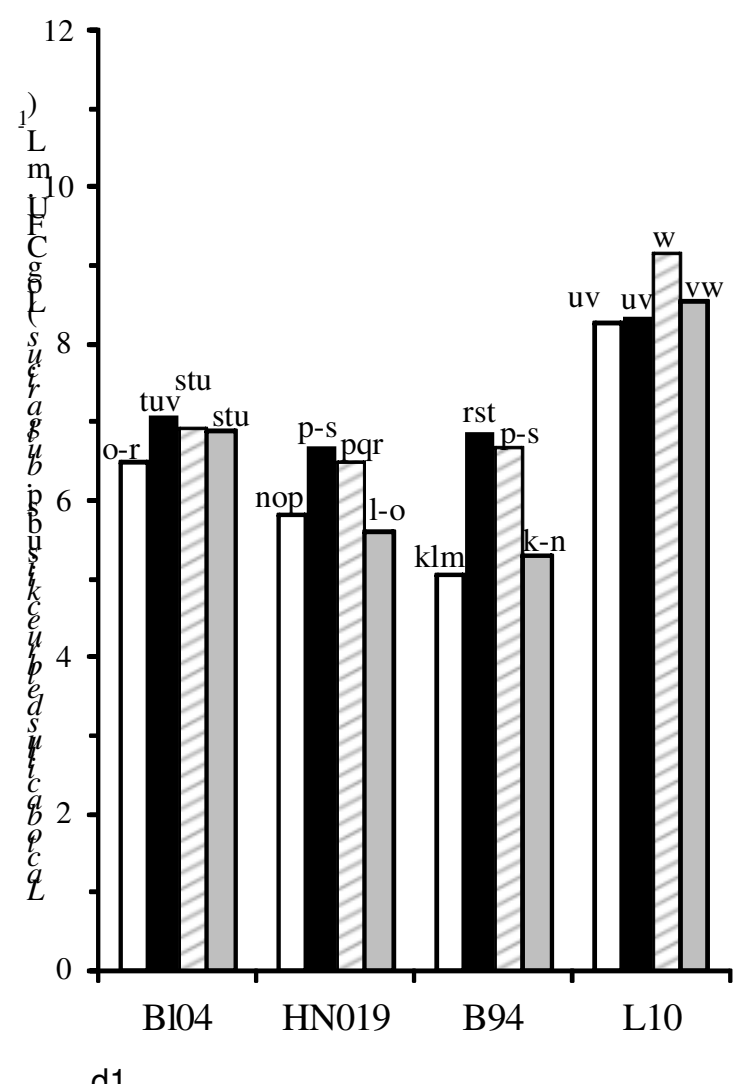

d1

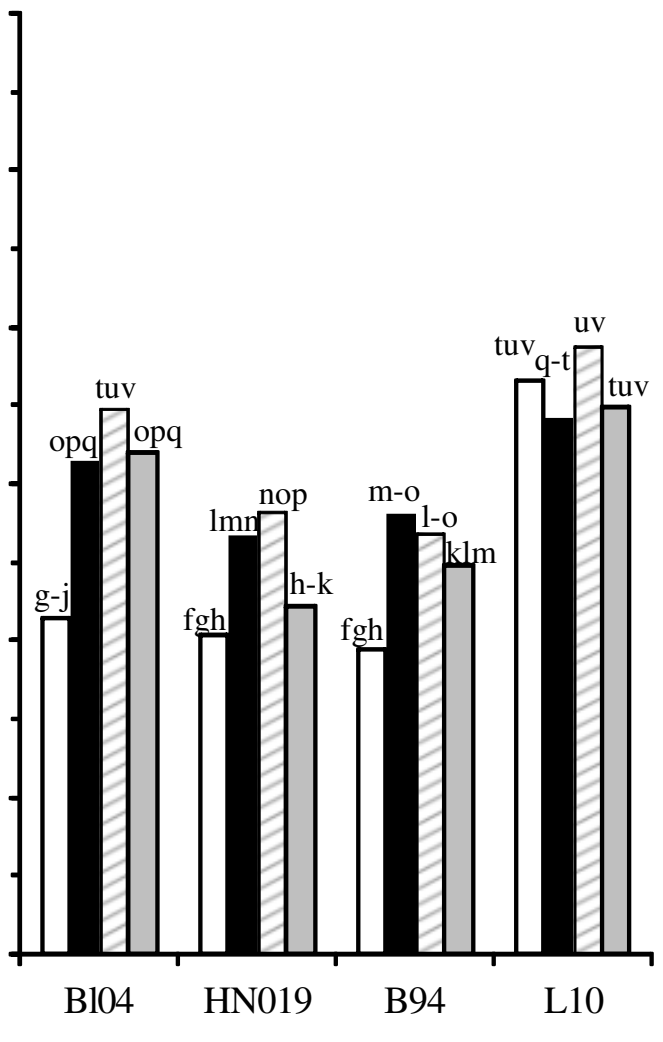

d14

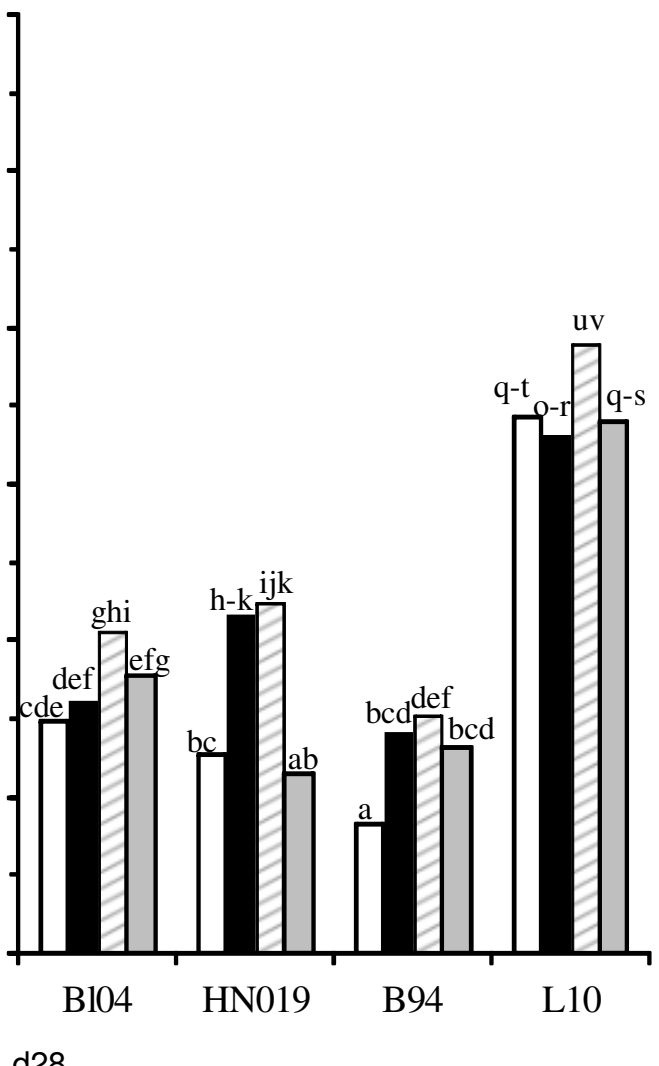

-Apple fiber

๑Banana fiber

口Passion fruit fiber

Figure 3.3. Lactobacillus delbrueckii subsp. bulgaricus counts in control and fiber yoghurts co-fermented by different probiotic strains.

Abbreviations: B104, HN019, B94 = yoghurts co-fermented by B. animalis subsp. lactis B104, HN019 and B94, respectively; L10 = yoghurts co-fermented by L. acidophilus L10. Means with different letters are significantly different $(P<0.05) . N=40 . \mathrm{d} 1, \mathrm{~d} 14$ and d $28=1,14$ and 28 days of cold storage. 


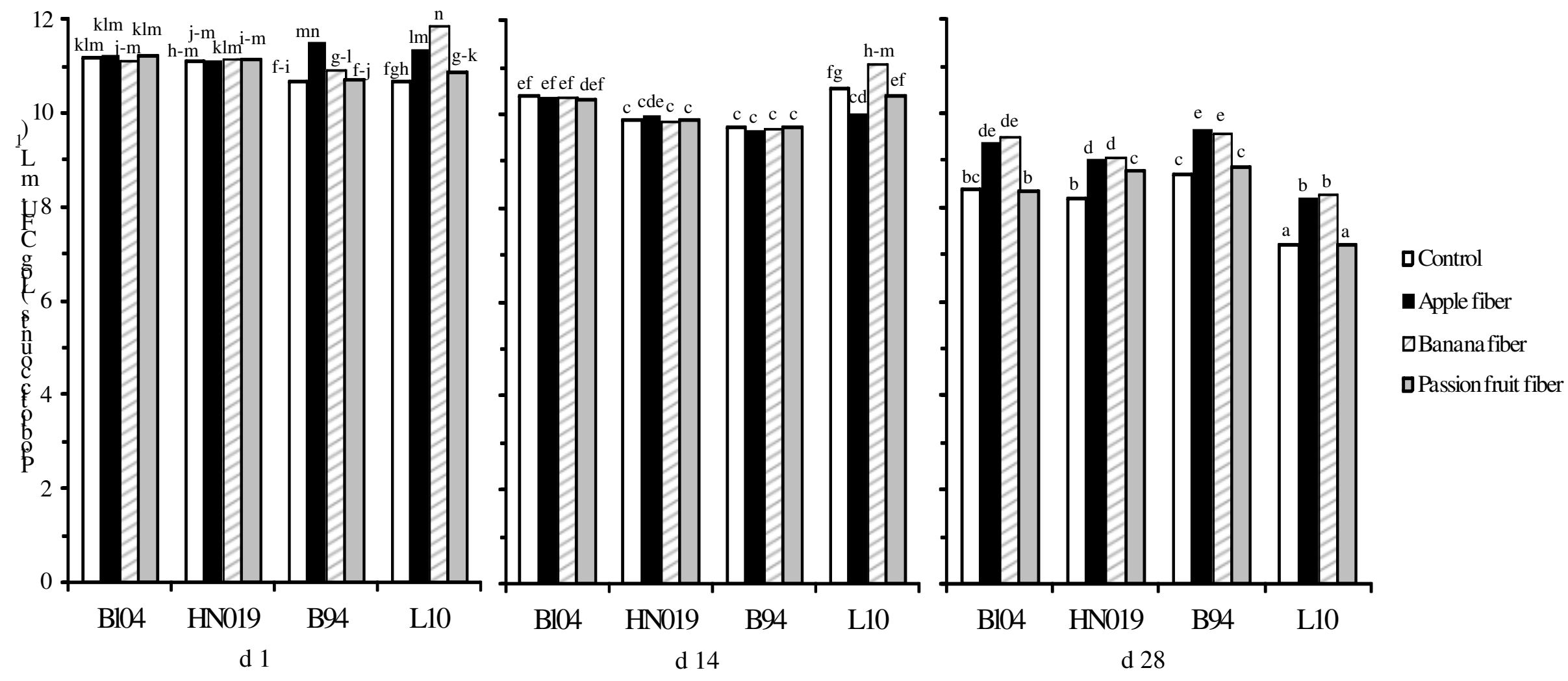

Figure 3.4. Probiotic counts in control and fiber yoghurts co-fermented by different probiotic strains.

Abbreviations: B104, HN019, B94 = yoghurts co-fermented by B. animalis subsp. lactis B104, HN019 and B94, respectively; L10 = yoghurts co-fermented by L. acidophilus L10. Means with different letters are significantly different $(P<0.05) . N=20 . \mathrm{d} 1, \mathrm{~d} 14$ and d $28=1,14$ and 28 days of cold storage. 
These observations point out an in vitro symbiotic effect of apple and banana fibers upon the probiotic strains tested, which was similar to those previously observed with orange, inulin, raftilose, maltodextrin, pectin and mainly with fructoolisaccharides on L. acidophilus and bifidobacteria (DESAI et al., 2004; ÖZER et al., 2005; SENDRA et al., 2008; OLIVEIRA et al., 2009). Based on these observations, one can relate the stimulating effect of both apple and banana fibers on probiotics to their high contents of pectins and fructooligosaccharides (SCHIEBER et al., 2001; EMAGA et al., 2008). On the other hand, in spite of the presence of pectin (YAPO \& KOFFI, 2008), the failure of the passion fruit fiber to increase probiotic counts $(P>0.05)$ could be ascribed to the simultaneous presence of inhibitory compounds such as antibacterial polyphenolics (RIPA et al., 2009). In spite of the count variations amongst the probiotic strains, the minimum therapeutic effective dose, which has been suggested to be between 6-9 Log CFU in the product (VASILJEVIC \& SHAH, 2008), was reached in all treatments until d 28.

As regards to the possible effect of the different fruit fibers on cell counts, one can see in Figures 3.2 to 3.4 taken as a plain, that the most significant count variations were detected after the longest storage time. In general, whereas no statistically significant effect was observed in all the counts of S. thermophilus, those of the other microorganisms decreased according to the following order: banana $>$ apple $>$ passion fruit, being in most cases the effects of the first two fibers statistically coincident. These results can be easily associated to the pectin polymerization degree of these fibers, which was approximately 67, 78, and 93\%, respectively (YAPO, 2009; RENARD et al., 1995). According to Bazzocco et al. (2008), the lower the polymerization degree of a polysaccharide, the higher its prebiotic effect likely because of easier fermentability.

\subsubsection{Fatty acids profile}

In previous study (ESPIRITO SANTO et al., 2010) the yoghurt starter co-culture CY340, made of S. thermophilus and L. delbrueckii subsp. bulgaricus, promoted an increase in the content of long chain fatty acids (LCFA) compared to non-fermented milk bases, but it had no effect on those of polyunsaturated fatty acids (PUFA) and CLA even in control yoghurts. Therefore, in the present study, we opted to work with the CY340 always in combination with one probiotic strain.

Table 3.3 shows the fatty acids profiles of skim milk bases, determined after heat treatment. Compared to the other milk bases as well as to the control, the content of short chain fatty acids (SCFA; C4:0 and C6:0) was significantly lower $(P<0.05)$ in banana fiber milk base and that of LCFA (C16:0 to 20:1) complementary higher in milk with apple or banana fiber. On the other hand, fiber addition had lower impact on the content of medium chain fatty acids (MCFA; C8:0 to C15:1). 
A rough indication of the fruit fiber fatty acid composition can be obtained by subtracting the data of milk bases with fibers from those without fibers.

According to the saturation degree of the carbon chain, the heat treated milk with apple fiber showed the lowest level of saturated fatty acids (SFA), while the control milk exhibited about one half the PUFA content of all the fiber-containing milks taken as an average $(P<0.05)$. Both effects should be ascribed to the typical compositions of the selected fibers, i.e. to a peculiar abundance of LCFA and PUFA in the banana and apple by-products, respectively (WU et al., 2007; EMAGA et al., 2008; MOHAPATRA et al., 2010). As far as the profiles of the most important fatty acids is concerned, the fiber addition did not lead to any significant variation in the average of stearic (18:0), oleic (18:1) and conjugated linoleic (c9t11-18:2) acids $(P>0.05)$, which were 12.4, 22.5 and $0.71 \mathrm{~g} / 100 \mathrm{~g}$ of lipids, respectively (Table 3.3). However, the control milk base exhibited approximately one half the linoleic acid $(18: 2)$ content of fiber added milk bases $(P<0.05)$ - which is an important precursor of CLA through the biohydrogenation pathway during lactic acid fermentation (EKINCI et al., 2008) - due to the abundance of such a fatty acid in the fibers (NYANZI et al., 2005; WU et al., 2007; EMAGA et al., 2008; LIU et al., 2008; MOHAPATRA et al., 2010).

The contents of $\alpha$-linolenic acid (18:3) in the presence of banana, passion fruit and apple fibers were respectively 7, 2 and 1.5-folds those observed in the control milk without fiber $(P<0.05)$, while the eicosanoic acid $(20: 1)$ was present in considerable amount only in milk with apple fiber $(P<0.05)$ (Table 3.3). These observations confirm that banana, passion fruit and apple peels are well-known sources of ALA, while the last fiber is also an interesting source of 20:1 (BLANCO-GOMIS et al., 2002; ORHAN et al., 2002; SONG \& BANGERTH, 2003; TOGASHI et al., 2007; WU et al., 2007; EMAGA et al., 2008; MOHAPATRA et al., 2010).

The fatty acids profile of the yoghurts remained statistically unchanged after 1,14 and 28 days of cold storage $(P>0.05)$ (data not shown); so, only the results of $\mathrm{d} 1$ are presented for discussion. This fact may be due to the slower activity of bacteria in yoghurt during cold storage, and the decrease in their viability (Figs. 3.2 to 3.4 ).

As the starter co-culture (CY340) was present in all samples and exhibited a minor effect on the fatty acids profile in previous work (ESPIRITO SANTO et al, 2010), the discussion on this issue was directed only to the effect of the probiotic strains and the fiber type on fatty acids profiles. 
Table 3.3. The fatty acids content in $\mathrm{g} / 100 \mathrm{~g}$ of lipids in total dietetic fibers and heat treated milk bases before fermentation.

\begin{tabular}{lllll}
\hline Fatty acid & Milk without fiber & Milk with apple fiber & Milk with banana fiber & Milk with passion fruit fiber \\
\hline SCFA & $3.68 \pm 0.6^{\mathrm{c}}$ & $3.53 \pm 0.07^{\mathrm{c}}$ & $2.18 \pm 0.1^{\mathrm{a}}$ & $3.27 \pm 0.03^{\mathrm{bc}}$ \\
$4: 0$ & $2.50 \pm 0.5^{\mathrm{a}}$ & $2.49 \pm 0.1^{\mathrm{a}}$ & $1.06 \pm 0.04^{\mathrm{b}}$ & $2.24 \pm 0.27^{\mathrm{a}}$ \\
$6: 0$ & $1.17 \pm 0.5^{\mathrm{b}}$ & $1.04 \pm 0.04^{\mathrm{a}}$ & $1.11 \pm 0.1^{\mathrm{a}}$ & $1.03 \pm 0.05^{\mathrm{b}}$ \\
\hline MCFA & $19.8 \pm 0.6^{\mathrm{b}}$ & $17.9 \pm 0.2^{\mathrm{a}}$ & $17.3 \pm 0.3^{\mathrm{a}}$ & $18.7 \pm 0.2^{\mathrm{ab}}$ \\
$8: 0$ & $1.39 \pm 0.4^{\mathrm{a}}$ & $1.36 \pm 0.1^{\mathrm{a}}$ & $0.83 \pm 0.04^{\mathrm{b}}$ & $1.16 \pm 0.1^{\mathrm{a}}$ \\
$10: 0$ & $2.33 \pm 0.2^{\mathrm{b}}$ & $2.02 \pm 0.2^{\mathrm{ab}}$ & $1.83 \pm 0.1^{\mathrm{a}}$ & $2.18 \pm 0.2^{\mathrm{ab}}$ \\
$12: 0$ & $2.80 \pm 0.5^{\mathrm{b}}$ & $2.49 \pm 0.05^{\mathrm{a}}$ & $2.48 \pm 0.2^{\mathrm{a}}$ & $2.71 \pm 0.2^{\mathrm{b}}$ \\
$14: 0$ & $11.42 \pm 0.3^{\mathrm{b}}$ & $10.36 \pm 0.4^{\mathrm{a}}$ & $10.43 \pm 0.3^{\mathrm{a}}$ & $10.76 \pm 0.3^{\mathrm{b}}$ \\
$14: 1$ & $0.64 \pm 0.01^{\mathrm{a}}$ & $0.58 \pm 0.02^{\mathrm{a}}$ & $0.58 \pm 0.01^{\mathrm{a}}$ & $0.62 \pm 0.02^{\mathrm{a}}$ \\
$15: 0$ & $1.22 \pm 0.1^{\mathrm{a}}$ & $1.08 \pm 0.2^{\mathrm{a}}$ & $1.12 \pm 0.1^{\mathrm{a}}$ & $1.24 \pm 0.2^{\mathrm{a}}$ \\
\hline LCFA & $76.5 \pm 0.6^{\mathrm{a}}$ & $78.6 \pm 0.5^{\mathrm{bc}}$ & $80.6 \pm 0.6^{\mathrm{c}}$ & $78.0 \pm 0.2^{\mathrm{ab}}$ \\
$16: 0$ & $34.66 \pm 0.8^{\mathrm{a}}$ & $32.41 \pm 0.2^{\mathrm{b}}$ & $36.98 \pm 0.7^{\mathrm{c}}$ & $33.91 \pm 0.6^{\mathrm{a}}$ \\
$16: 1$ & $0.57 \pm 0.04^{\mathrm{a}}$ & $0.49 \pm 0.02^{\mathrm{a}}$ & $0.61 \pm 0.05^{\mathrm{a}}$ & $0.56 \pm 0.04^{\mathrm{a}}$ \\
$18: 0$ & $13.0 \pm 0.4^{\mathrm{a}}$ & $11.9 \pm 0.4^{\mathrm{a}}$ & $12.8 \pm 0.4^{\mathrm{a}}$ & $12.7 \pm 0.5^{\mathrm{a}}$ \\
$18: 1$ & $22.6 \pm 0.7^{\mathrm{a}}$ & $22.4 \pm 0.8^{\mathrm{a}}$ & $22.3 \pm 0.8^{\mathrm{a}}$ & $22.8 \pm 0.6^{\mathrm{a}}$ \\
$18: 2$ & $2.42 \pm 0.09^{\mathrm{a}}$ & $5.82 \pm 0.14^{\mathrm{c}}$ & $5.31 \pm 0.17^{\mathrm{c}}$ & $4.15 \pm 0.17^{\mathrm{b}}$ \\
CLA & $0.72 \pm 0.05^{\mathrm{a}}$ & $0.68 \pm 0.03^{\mathrm{a}}$ & $0.69 \pm 0.04^{\mathrm{a}}$ & $0.74 \pm 0.04^{\mathrm{a}}$ \\
ALA & $0.23 \pm 0.03^{\mathrm{a}}$ & $0.35 \pm 0.03^{\mathrm{b}}$ & $1.45 \pm 0.08^{\mathrm{d}}$ & $0.53 \pm 0.05^{\mathrm{c}}$ \\
$20: 1$ & $0.00 \pm 0.00^{\mathrm{a}}$ & $2.60 \pm 0.11^{\mathrm{b}}$ & $0.00 \pm 0.00^{\mathrm{a}}$ & $0.00 \pm 0.00^{\mathrm{a}}$ \\
\hline SFA & $70.5 \pm 1.6^{\mathrm{c}}$ & $65.2 \pm 1.3^{\mathrm{a}}$ & $68.6 \pm 0.4^{\mathrm{bc}}$ & $68.0 \pm 0.3^{\mathrm{b}}$ \\
\hline MUFA & $26.1 \pm 0.5^{\mathrm{ab}}$ & $28.0 \pm 1.2^{\mathrm{ab}}$ & $24.9 \pm 0.6^{\mathrm{a}}$ & $26.3 \pm 0.1^{\mathrm{b}}$ \\
\hline PUFA & $3.37 \pm 1.16^{\mathrm{a}}$ & $6.85 \pm 0.08^{\mathrm{c}}$ & $6.43 \pm 0.22^{\mathrm{bc}}$ & $5.70 \pm 0.43^{\mathrm{b}}$
\end{tabular}

Means \pm standard deviation with different letters in the same line are significantly different $(P<0.05), N=12$.

Abbreviations: short chain fatty acid (SCFA, C4:0 to C6:0); medium chain fatty acid (MCFA, C8:0 to C15:1); long chain fatty acid (LCFA, C16:0 to C18:3). SFA, Saturated fatty acid; MUFA, Monounsaturated fatty acid; PUFA, Polyunsaturated fatty acid. 18:0, Stearic acid; 18:1, Oleic acid; 18:2, Linoleic acid; 20:1, Eicosanoic acid; ALA, $\alpha-$ Linolenic acid, 18:3; CLA, Conjugated linoleic acid (c9t11-18:2).

Fibers significantly stimulated the production of SCFA $(P<0.05)$ (Table 3.4), which varied, after $\mathrm{d} 1$, in the range $2.75-3.37 \mathrm{~g} / 100 \mathrm{~g}$ of lipids in the controls and in the range 3.16-6.08 $\mathrm{g} / 100 \mathrm{~g}$ of lipids in fiber yoghurts, respectively. In particular, the banana fiber yoghurt co-fermented by L. acidophilus L10 showed the highest fraction of these fatty acids $(P<0.05)$. Edwards and Parret (2002) reported that bacteria from intestinal microbiota ferment unabsorbed carbohydrate to SCFA, which have health benefits related to prevention of heart disease and cancer. A wide range of bowel 
bacteria can ferment plant cell-wall biopolymers such as pectins, xylans, arabinogalactans, gums and mucilages into SCFA (MACFARLANE \& MACFARLANE, 2003; COSKUN \& ONDUL, 2004; YADAV et al., 2007). Moreover, in vitro experiments demonstrated that bacteria present in the gut are able to ferment individual polysaccharides such starch and pectin into SCFA more rapidly than xylan or arabinogalactan (MACFARLANE \& MACFARLANE, 2003). Since the fruit fibers tested in this work are rich in pectins and fructooligosaccharides, they may have provided substrate for the production of SCFA by the probiotic strains.

The contents of MCFA in control yoghurts ranged from 17.34 to $20.41 \mathrm{~g} / 100 \mathrm{~g}$ of lipids and were, in general, higher than in those with fruit fiber $(P<0.05)$, in which the MCFA content ranged from 15.67 to $18.47 \mathrm{~g} / 100 \mathrm{~g}$ of lipids (Table 3.4).

The LCFA content ranged from 75.22 to $80.51 \mathrm{~g} / 100 \mathrm{~g}$ of lipids and constituted the highest lipid fraction in all the yoghurts tested in this work. In general, the fibers promoted the increase in LCFA content of yoghurts compared to the controls, with the exception of banana fiber, as milk containing this supplement showed a LCFA content before fermentation higher than the corresponding yoghurts (Tables 3.3 and 3.4).

These results agree with those found by Espírito Santo et al. (2010), who observed an increase in the production of LCFA in yoghurt co-fermented by the same probiotics in the presence of açai pulp, and pointed out a complex relationship between probiotic strain and fruit ingredient upon the production and transformation of fatty acids.

Figure 3.5 shows that the content of SFA in the control yoghurts ranged from 68.2 to 71.8 $\mathrm{g} / 100 \mathrm{~g}$ of lipids and was higher than in fiber yoghurts $(61.7-68.8 \mathrm{~g} / 100 \mathrm{~g}$ of lipids; $P<0.05)$. Such a generalized reduction in the SFA level induced by fibers was more marked in the apple fiber yoghurts, particularly that co-fermented by L. acidophilus L10 $(12 \%$ reduction $)(P<0.05)$.

The highest contents of monounsaturated fatty acids were detected in apple fiber yoghurts regardless of the probiotic strain $(P<0.05)$. Taking into account that the original milk bases showed statistically coincident contents of MUFA $(P>0.05)$ (Table 3.3), this observation suggests the occurrence of a positive interaction between the lipid compounds of the apple fiber and the activity of lactic acid bacteria (Figure 3.5). 
Table 3.4. Fatty acids content in $\mathrm{g} / 100 \mathrm{~g}$ of lipids in the yoghurts.

\begin{tabular}{|c|c|c|c|c|c|c|c|}
\hline Samples & SCFA & MCFA & LCFA & 18:0 & $18: 1(9 c)$ & $18: 2(6 c)$ & 20:1 \\
\hline CB104 & $3.04 \pm 0.2^{\mathrm{ab}}$ & $17.90 \pm 0.2^{\mathrm{de}}$ & $78.06 \pm 0.2^{\text {cde }}$ & $14.00 \pm 0.5^{\mathrm{h}}$ & $24.45 \pm 0.7^{\mathrm{tgh}}$ & $2.85 \pm 0.1^{\mathrm{b}}$ & $0.00 \pm 0.0^{\mathrm{a}}$ \\
\hline CB94 & $3.37 \pm 0.5^{\mathrm{bc}}$ & $20.41 \pm 0.2^{\mathrm{g}}$ & $75.22 \pm 0.7^{\mathrm{a}}$ & $13.77 \pm 0.4^{\mathrm{gh}}$ & $21.69 \pm 0.5^{\mathrm{a}}$ & $2.08 \pm 0.1^{\mathrm{a}}$ & $0.00 \pm 0.0^{\mathrm{a}}$ \\
\hline CHNO19 & $2.75 \pm 0.4^{\mathrm{a}}$ & $19.03 \pm 0.3^{\mathrm{f}}$ & $77.23 \pm 0.5^{\mathrm{bc}}$ & $12.55 \pm 0.3^{\text {cde }}$ & $24.80 \pm 0.6^{\mathrm{fgh}}$ & $3.15 \pm 0.1^{\mathrm{b}}$ & $0.00 \pm 0.0^{\mathrm{a}}$ \\
\hline CL10 & $2.76 \pm 0.4^{\mathrm{a}}$ & $17.34 \pm 0.1^{\mathrm{cd}}$ & $76.23 \pm 0.5^{\mathrm{ab}}$ & $13.70 \pm 0.4^{\mathrm{gh}}$ & $23.19 \pm 0.4^{\text {cde }}$ & $2.65 \pm 0.1^{\mathrm{ab}}$ & $0.00 \pm 0.0^{\mathrm{a}}$ \\
\hline AB104 & $3.90 \pm 0.5^{\text {cde }}$ & $16.72 \pm 0.2^{\mathrm{abc}}$ & $79.37 \pm 0.3^{\mathrm{efg}}$ & $12.05 \pm 0.5^{\mathrm{abc}}$ & $23.74 \pm 0.8^{\mathrm{def}}$ & $6.18 \pm 0.3^{\text {fgh }}$ & $2.79 \pm 0.1^{\mathrm{c}}$ \\
\hline AB94 & $4.01 \pm 0.3^{\mathrm{de}}$ & $17.15 \pm 0.4^{\mathrm{cd}}$ & $78.83 \pm 0.4^{\mathrm{def}}$ & $11.91 \pm 0.5^{\mathrm{ab}}$ & $23.30 \pm 0.9^{\text {cde }}$ & $6.67 \pm 0.3^{\mathrm{hi}}$ & $3.15 \pm 0.2^{\mathrm{d}}$ \\
\hline AHN019 & $3.35 \pm 0.6^{\mathrm{bc}}$ & $16.81 \pm 0.2^{\mathrm{bc}}$ & $80.18 \pm 0.5^{\mathrm{fg}}$ & $11.69 \pm 0.3^{\mathrm{a}}$ & $24.79 \pm 0.8^{\mathrm{h}}$ & $6.35 \pm 0.3^{\text {ghi }}$ & $2.52 \pm 0.2^{\mathrm{b}}$ \\
\hline AL10 & $4.42 \pm 0.5^{\mathrm{e}}$ & $15.67 \pm 0.3^{\mathrm{a}}$ & $79.90 \pm 0.6^{\mathrm{fg}}$ & $12.61 \pm 0.4^{\mathrm{cde}}$ & $23.47 \pm 0.2^{\text {cef }}$ & $6.97 \pm 0.3^{\mathrm{i}}$ & $3.14 \pm 0.3^{\mathrm{d}}$ \\
\hline BB104 & $3.89 \pm 0.6^{\mathrm{cde}}$ & $17.98 \pm 0.2^{\text {def }}$ & $80.11 \pm 0.7^{\mathrm{fg}}$ & $12.66 \pm 0.3^{\text {cde }}$ & $21.94 \pm 0.4^{\mathrm{ab}}$ & $5.43 \pm 0.1^{\mathrm{e}}$ & $0.00 \pm 0.0^{\mathrm{a}}$ \\
\hline BB94 & $3.38 \pm 0.7^{\mathrm{bc}}$ & $17.61 \pm 0.4^{\mathrm{cd}}$ & $80.00 \pm 0.7^{\mathrm{fg}}$ & $12.89 \pm 0.2^{\mathrm{def}}$ & $21.82 \pm 0.6^{\mathrm{a}}$ & $5.53 \pm 0.2^{\mathrm{ef}}$ & $0.00 \pm 0.0^{\mathrm{a}}$ \\
\hline BHN019 & $3.16 \pm 0.2^{\mathrm{ab}}$ & $17.41 \pm 0.2^{\mathrm{cd}}$ & $80.43 \pm 0.4^{g}$ & $12.20 \pm 0.5^{\mathrm{abc}}$ & $22.41 \pm 0.6^{\mathrm{abc}}$ & $5.95 \pm 0.2^{\mathrm{efg}}$ & $0.00 \pm 0.0^{\mathrm{a}}$ \\
\hline BL10 & $6.08 \pm 0.5^{\mathrm{t}}$ & $16.84 \pm 0.3^{\mathrm{bc}}$ & $77.08 \pm 0.3^{\mathrm{bc}}$ & $12.92 \pm 0.4^{\mathrm{def}}$ & $21.65 \pm 0.2^{\mathrm{a}}$ & $6.00 \pm 0.2^{\mathrm{etg}}$ & $0.00 \pm 0.0^{\mathrm{a}}$ \\
\hline PB104 & $3.47 \pm 0.5^{\mathrm{bcd}}$ & $16.60 \pm 0.5^{\mathrm{abc}}$ & $79.93 \pm 0.4^{\mathrm{fg}}$ & $13.98 \pm 0.7^{\mathrm{h}}$ & $24.53 \pm 0.2^{\mathrm{gh}}$ & $4.59 \pm 0.1^{\mathrm{d}}$ & $0.00 \pm 0.0^{\mathrm{a}}$ \\
\hline PB94 & $4.07 \pm 0.2^{\mathrm{e}}$ & $18.47 \pm 0.2^{\mathrm{ef}}$ & $77.26 \pm 0.5^{\mathrm{bc}}$ & $13.13 \pm 0.5^{\mathrm{efg}}$ & $22.81 \pm 0.2^{\mathrm{bcd}}$ & $3.90 \pm 0.1^{\mathrm{c}}$ & $0.00 \pm 0.0^{\mathrm{a}}$ \\
\hline PHN019 & $3.96 \pm 0.5^{\mathrm{de}}$ & $18.03 \pm 0.6^{\mathrm{def}}$ & $77.97 \pm 0.3^{\mathrm{bc}}$ & $12.37 \pm 0.2^{\mathrm{bcd}}$ & $23.09 \pm 0.3^{\mathrm{bcd}}$ & $4.24 \pm 0.2^{\mathrm{cd}}$ & $0.00 \pm 0.0^{\mathrm{a}}$ \\
\hline PL10 & $3.91 \pm 0.3^{\text {cde }}$ & $15.87 \pm 0.2^{\mathrm{ab}}$ & $80.51 \pm 0.4^{\mathrm{g}}$ & $13.54 \pm 0.3^{\text {fgh }}$ & $23.48 \pm 0.3^{\mathrm{dfg}}$ & $5.47 \pm 0.3^{\mathrm{e}}$ & $0.00 \pm 0.0^{\mathrm{a}}$ \\
\hline
\end{tabular}

Means \pm standard deviation with different letters in the same line are significantly different $(P<0.05), N=12$.

Abbreviations: short chain fatty acid (SCFA, C4:0 to C6:0); medium chain fatty acid (MCFA, C8:0 to C15:1); long chain fatty acid (LCFA, C16:0 to C18:3). 18:0, Stearic acid; 18:1 (9c), Oleic acid; 18:2 (6c), Linoleic acid; 20:1, Eicosanoic acid. Yoghurts co-fermented by L. acidophilus L10: control (CLa), with apple fiber (ALa), with banana fiber (BLa), with passion fruit fiber (PLa). Yoghurts co-fermented by B. animalis subsp. lactis B104: control (CB104), with apple fiber (AB104), with banana fiber (BB104), with passion fruit fiber (PB104). Yoghurts co-fermented by B. animalis subsp. lactis B94: control (CB94), with apple fiber (AB94), with banana fiber (BB94), with passion fruit fiber (PB94). Yoghurts co-fermented by B. animalis subsp. lactis HN019: control (CHN019), with apple fiber (AHN019), with banana fiber (BHN019), with passion fruit fiber (P HN019).

Interestingly, all fiber yoghurts showed PUFA contents remarkably higher than their respective controls $(P<0.05)$ (Figure 3.5). Noteworthy is the increase in PUFA content mainly promoted by banana fiber in yoghurts co-fermented by bifidobacteria, in addition to that resulting from the banana fiber addition to the milk base (Table 3.3). On the other hand, the PUFA content was significantly increased by apple and passion fruit fibers in the presence of L. acidophilus L10 $(P<0.05)$. Also such significant differences in the PUFA contents could be ascribed to the above- 
mentioned synergistic interaction between fruit fiber type and probiotic strain. The increase in unsaturation degree has already been reported for several microorganisms that was suggested to be a universally conserved adaptation response (GUERZONI et al., 2001). These results are of great concern because the adhesion of probiotics to the mucosal wall of the distal intestine portion can be promoted by PUFA (KANKAANPÄA et al., 2001; DAS \& FAMS, 2002). Thus, one should expect that yoghurts containing anyone of the tested fibers could improve the viability of probiotic bacteria and their colonization ability.

In control yoghurts without fibers, the level of CLA (c9 t11-18:2), one of the most important fatty acids for human health, ranged from $0.47 \mathrm{~g}$ to $0.80 \mathrm{~g} / 100 \mathrm{~g}$ of lipids (Figure 3.6A). The control yoghurts co-fermented by $B$. animalis subsp. lactis exhibited CLA content near to the content found in the milk bases, but about 50\% higher than those co-fermented by L. acidophilus L10, which demonstrates that CLA production is species dependent. Furthermore, the CLA amount in control yoghurt co-fermented by the same strain $(0.47 \mathrm{~g} / 100 \mathrm{~g}$ of lipids, Figure $3.6 \mathrm{~A})$ was lower than in the milk base $(0.72 \mathrm{~g} / 100 \mathrm{~g}$ of lipids, Table 3.3$)$, showing that in this case part of the initial CLA was transformed in others fatty acids. These observations are supported by the results of previous studies that highlighted different abilities of Lactobacillus, Lactococcus and Bifidobacterium species and strains to produce CLA during milk fermentation (EKINCI et al., 2008; OLIVEIRA et al., 2009; ESPÍRITO SANTO et al., 2010). 


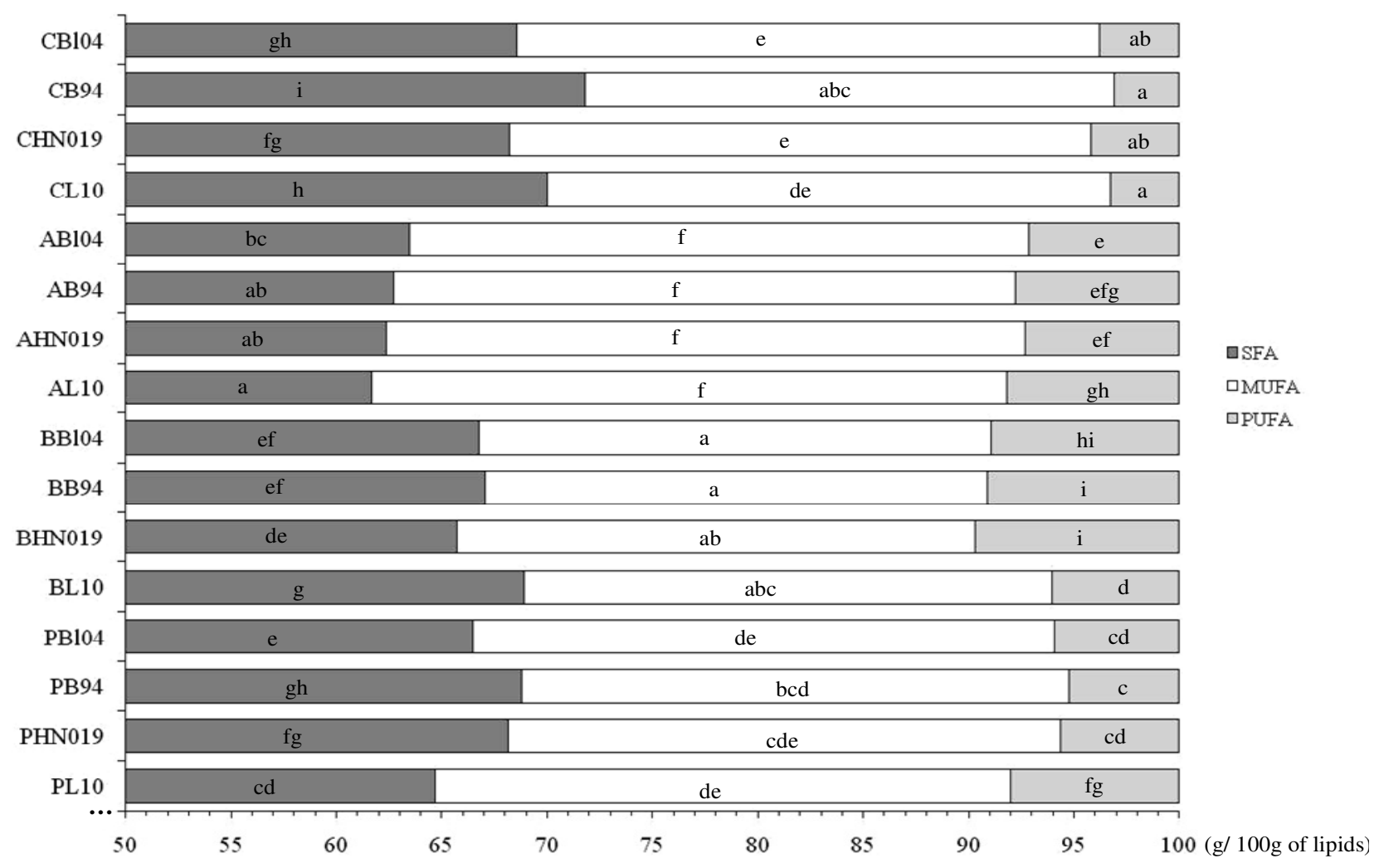

Figure 3.5. Fatty acid profiles (g/100 g of lipids), according to the saturation degree of the carbon chain, observed in control and fiber yoghurts 1 day after the fermentation by different probiotics. Means with different letters are significantly $(P<0.05)$ different. $N=12$. Abbreviations: SFA = Saturated fatty acid; MUFA = Monounsaturated fatty acid; PUFA = Polyunsaturated fatty acid. Yoghurts co-fermented by L. acidophilus L10: control (CL10), with apple fiber (AL10), with banana fiber (BL10), with passion fruit fiber (PL10). Yoghurts co-fermented by B. animalis subsp. lactis B104: control (CB104), with apple fiber (AB104), with banana fiber (BB104), with passion fruit fiber (PB104). Yoghurts co-fermented by B. animalis subsp. lactis B94: control (CB94), with apple fiber (AB94), with banana fiber (BB94), with passion fruit fiber (PB94). Yoghurts co-fermented by B. animalis subsp. lactis HN019: control (CHN019), with apple fiber (AHN019), with banana fiber (BHN019), with passion fruit fiber (PHN019). 
In fiber yoghurts, the CLA content ranged from $0.54 \mathrm{~g}$ to $1.12 \mathrm{~g} / 100 \mathrm{~g}$ of lipids and was significantly higher $(P<0.05)$ in those supplemented with the passion fruit fiber (Figure 3.6A). In general, it was observed a negative effect of banana fiber on CLA content in yoghurt co-fermented by $B$. animalis subsp. lactis strains compared to the controls. Unexpectedly, this lowering in the CLA amount in banana fiber yoghurts was not followed by the lowering of linoleic acid (18:2), one of the CLA precursors, nor by the increase in the oleic acid (18:0) content, the final product of the biohydrogenation (Table 3.4). In addition, yoghurts containing apple and banana fibers and cofermented by B. animalis subsp. lactis B94 exhibited mean CLA values similar to those of their milk bases, suggesting that there was no effect on CLA production during fermentations. Amongst the yoghurts fermented by $B$. animalis subsp. lactis HN019, apple and passion fruit fibers led to the highest contents of CLA. But, the most pronounced effect on the CLA content was observed in the presence of L. acidophilus L10 (Figure 3.6), which, despite the lowest level of this acid in its control, exhibited the highest increases in fiber yoghurts $(P<0.05)$, especially using the passion fruit and banana fibers, both notoriously rich in pectins. Since the CLA level did not show any statistically significant difference in heat treated milk bases $(P>0.05)$ (Table 3.3) and was the lowest in the control yoghurt co-fermented by L. acidophilus L10 $(P<0.05)$ (Figure 3.6), such an effect can certainly be ascribed only to the supplementation and the type of fibers. The generalized higher CLA content in yogurts containing passion fruit fiber compared to controls, in the presence of all the selected strains, is the most evident proof of the possibility of stimulating CLA formation in yoghurts by fruit fiber addition.

However, it is not possible in the present study to suppose a direct relationship between the contents of CLA in fiber yoghurts and of its precursor [linoleic acid (18:2)] in milk bases, because the concentration of linoleic acid was, as an average, significantly higher $(P<0.05)$ in apple and banana fiber milk bases than in passion fruit ones (Table 3.3). As mentioned in the Introduction, the selected dietary fibers are rich sources of many prebiotics, mainly pectins and fructooligosaccharides, which were likely responsible for the observed increases in CLA content. Akalin et al. (2007) and Oliveira et al. (2009) reported that some combinations of probiotic strains, among which L. acidophilus and B. animalis, and prebiotics such as fructooligosaccharides are able to stimulate the CLA production in fermented milk. 
(A)

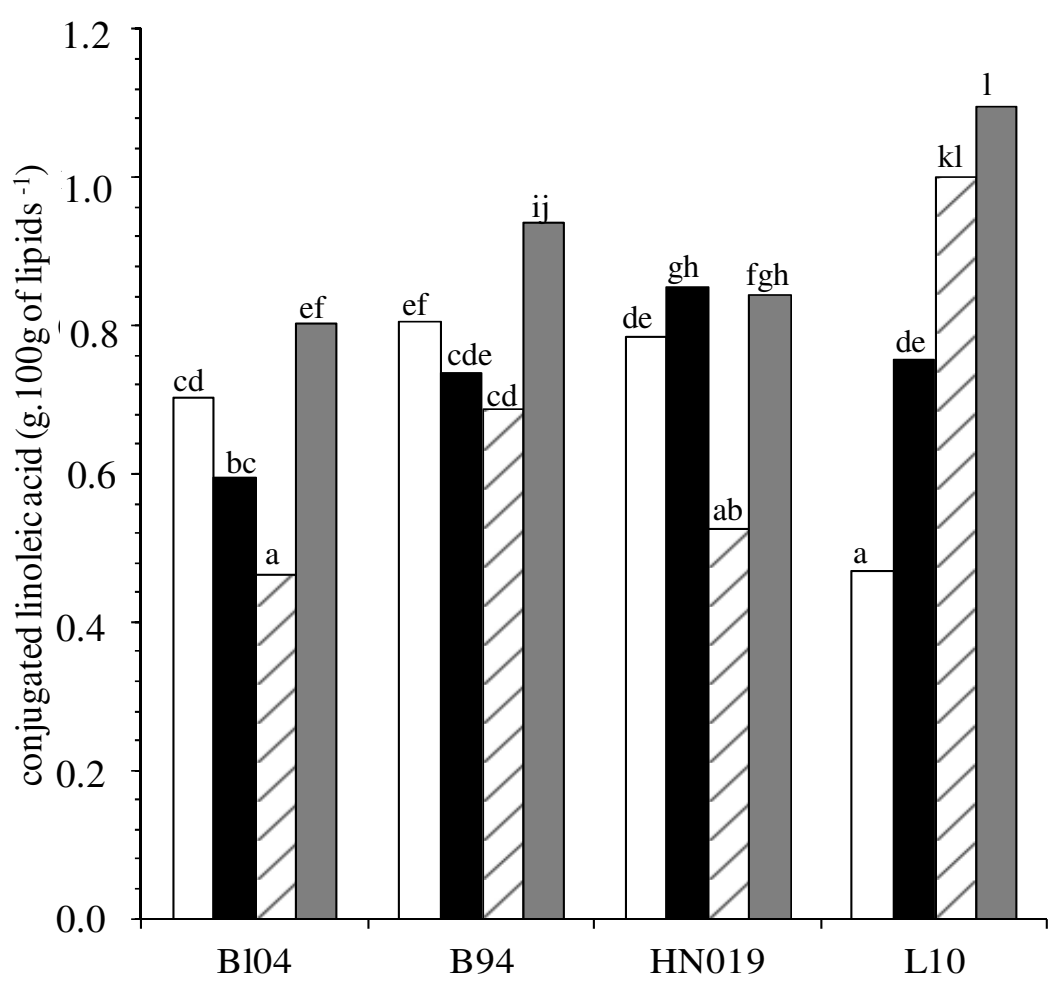

(B)

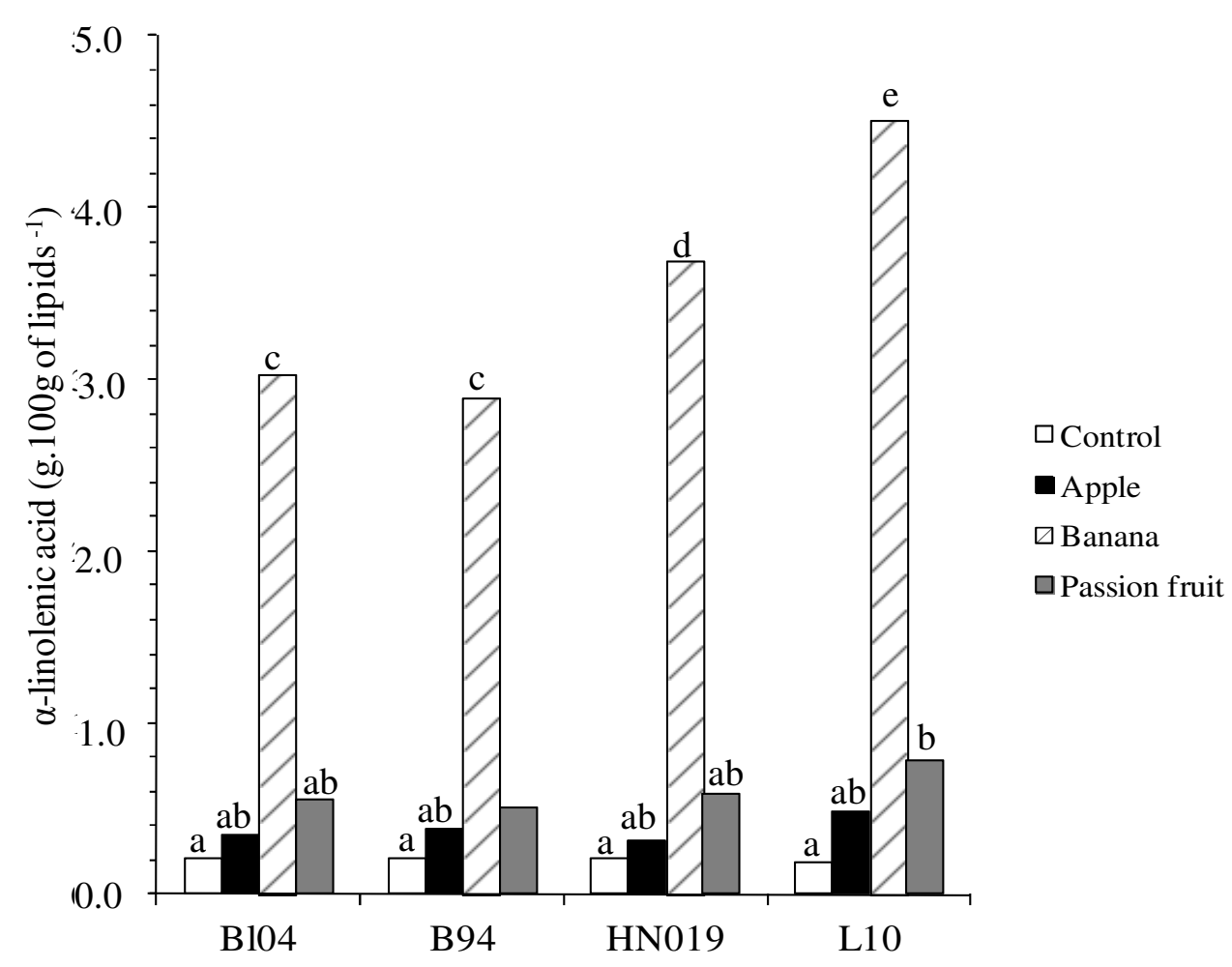

Figure 3.6. Contents of (A) conjugated linoleic acid and (B) $\alpha$-Linolenic acid in control and fiber yoghurts co-fermented by different probiotic strains. Abbreviations: Bl04, HN019, B94 = yoghurts co-fermented by B. animalis subsp. lactis B104, HN019 and B94, respectively; L10 = yoghurts co-fermented by L. acidophilus L10. Means with different letters are significantly different $(P<0.05) . \quad N=12$. 
These findings on the plain suggest that multiple factors including fiber composition and probiotic strain may be synergistically involved in the CLA production.

Finally, the contents of ALA were around $0.20 \mathrm{~g} / 100 \mathrm{~g}$ of lipids in control yoghurts, and ranged from $0.31 \mathrm{~g}$ to $4.51 \mathrm{~g} / 100 \mathrm{~g}$ of lipids in fiber yoghurts (Figure 3.6B). As a result of the high ALA content of banana peel (EMAGA et al., 2008), all the banana fiber yoghurts showed remarkable increases in the level of such polyunsaturated fatty acid with respect to their controls, when compared to the other treatments. An additional synergistic role of the probiotic strains is also suggested by the ALA level that increased, in the presence of this fiber, from $2.8 \mathrm{~g} / 100 \mathrm{~g}$ with $B$. animalis subsp. lactis B104 and B94 to $3.7 \mathrm{~g} / 100 \mathrm{~g}$ with B. animalis subsp. lactis HN019 and to 4.5 $\mathrm{g} / 100 \mathrm{~g}$ of lipids with $L$. acidophilus L10 $(P<0.05)$. The passion fruit fiber also stimulated the ALA production in yoghurts fermented by L. acidophilus L10 compared to the control $(P<0.05)$ (Figure 3.6B). These observations are noteworthy since the dietary ingestion of ALA is a factor of inhibition of the proinflammatory cytokine production, which can prevent cardiovascular diseases (ZHAO et al., 2007).

\subsection{Conclusions}

Apple and banana fiber helped to preserve the viability until the fourth week of cold storage of all probiotic strains tested in this study for the production of fiber-enriched skim yoghurts, namely Bifidobacterium animalis subsp. lactis B104, HN019 and B94 and Lactobacillus acidophilus L10. All fiber yoghurts exhibited higher amount of short chain fatty acids and polyunsaturated fatty acids than their controls. There was a synergistic effect between the type of fiber and the probiotic strain on the level of conjugated linoleic acid (c9, t11). Noteworthy, passion fruit fiber promoted CLA increase in all probiotic yoghurts, and all the fruit fibers tested overcame the negative effect of the L. acidophilus L10 on the CLA amount in the yoghurts. The content of $\alpha$-linolenic acid was remarkably increased by the addition of banana fiber. These observations point to the applicability of these processing fruit by-products in the development of new high nutritional value-added probiotic yoghurts. 


\section{CHAPTER IV}

\section{Influence of Milk Type and Passion Fruit Fiber Addition On Kinetics, Texture Profiles and Bacteria Viability in Probiotic Yoghurts}

\subsection{Introduction}

The passion fruit has origin in tropical countries of America, and Brazil is its greatest producer and consumer, exporting the fruit mainly to United Kingdom, France, Belgium, German and the Netherlands (EMBRAPA, 2010). The cultivation of yellow passion fruit (Passiflora edulis var. flavicarpa Deg., Passifloraceae) has been preferred for industrial juice production that generates large quantities of by-product composed by seeds and shells representing more than half of the total fruit weight (SALGADO et al., 2010).

Functional properties such as anti-hypertensive, hypocholesterolemic and reduction of blood glucose level, have been attributed to the passion fruit peel (CHAU \& HUANG, 2005; ZIBADI et al., 2007; JANEBRO et al., 2008; SALGADO et al., 2010). Beyond the content of 10$20 \%$ of pectin, a soluble fiber which is known for its prebiotic action, the passion fruit peel is composed of approximately $1.5 \mathrm{~g}$ of protein, $0.8 \mathrm{~g}$ of lipids, $8.7 \mathrm{~g}$ of ash, $56 \mathrm{~g}$ of carbohydrates per $100 \mathrm{~g}$ of dry matter and is also a source of iron, calcium, phosphorus and niacin (CORDOVA et al., 2005; YAPO \& KOFFI, 2008). Therefore, it should not be regarded just as an industrial waste, since it can be used for the development of new functional products such as the probiotic ones.

Both dietary fiber and probiotics are reported to relieve constipation and reduce the incidence of colon cancer (KAUR \& GUPTA, 2002; FARNWORTH, 2008). In addition, some dietetic fibers from fruit have been recommended as ingredient to probiotic dairy foods because of their beneficial effect on the viability of these bacteria (KOURKOUTAS et al, 2006; SENDRA et al, 2008; ESPIRITO SANTO et al., 2010). However, from the technological point of view the addition of fruit dietetic fiber into a food product with a smooth texture such as yoghurt is a challenge. Both the fermentation and the fragile equilibrium of yoghurt structure can be affected by any fiber added into the milk as well as by the milk type itself (KUMAR \& MISHRA, 2003; SODINI et al., 2004, STAFFOLO et al., 2004; SENDRA et al., 2008). The analysis of the texture profile of yoghurt-like products offers some advantages such as reduced test time and quantification 
of structural breakdown, being a useful technique to evaluate the protein gel strength (KUMAR \& MISHRA, 2003).

The influence of the milk type and the addition of total dietetic fiber from fruits on kinetics and textural properties of fermented milk products still have been underexploited. This study aimed at evaluating the effect of the milk type and of the total dietetic fiber obtained from passion fruit byproduct on the kinetic and texture parameters, post-acidification and microorganism counts of probiotic yoghurts during four weeks of cold storage.

\subsection{Materials and Methods}

\subsubsection{Total dietary fiber preparation}

Passion fruit by-product was obtained from an industry of fruit pulp located in the city of Jundiai, São Paulo State, Brazil. The peels of passion fruit were dried in oven under air flow at $60^{\circ} \mathrm{C}$ until constant weight. The dry peels were reduced to fine powder in a Bimby processor (model TM 31, Vorwerk ${ }^{\circledR}$, Wuppertal, Germany). In order to make the mixture of the fiber powder into the reconstituted milk easier, the particle size was standardized to less than $42 \mu \mathrm{m}$, measured through sieves (Granutest, São Paulo, Brazil). The fiber powder was stored in clapped glass bottles and kept under refrigeration at $4^{\circ} \mathrm{C}$ until use.

\subsubsection{Milk preparation}

Skimmed milk Molico ${ }^{\circledR}$ and plain milk Ninho ${ }^{\circledR}$ powders (Nestlé, Araçatuba, Brazil) were both reconstituted to $12 \%(\mathrm{w} / \mathrm{w})$ in distilled water and each one was divided into two milk samples. Passion fruit fiber was added up to $0.7 \%$ to one sample of each of these milks, while the other without fiber was used as control. This percentage of total fiber addition was the highest amount that caused the minimum sineresis by the end of the fermentation (data not shown). All milk bases were heat treated at $85^{\circ} \mathrm{C}$ for $15 \mathrm{~min}$ under agitation in a water bath and then divided into sterile Schott ${ }^{\circledR}$ flasks $(500 \mathrm{~mL})$, cooled in an ice bath, and stored at $4^{\circ} \mathrm{C}$ for $24 \mathrm{~h}$.

\subsubsection{Microbial cultures}

We used in this study a freeze-dried starter yoghurt culture (CY340. DSM, Moorebank, NSW, Australia) - composed of Streptococcus thermophilus (St) and Lactobacillus delbrueckii subsp. bulgaricus (Lb) - and four probiotics, namely two strains of Lactobacillus acidophilus (L10. DSM, and NCFM. Danisco, Madison, WI, USA) and two strains of Bifidobacterium animalis subsp. lactis (B104 and HN019. Danisco). The lyophilized cultures were diluted in sterilized milk 
and divided into aliquots into Eppendorf ${ }^{\circledR}$ flasks and frozen at $-20{ }^{\circ} \mathrm{C}$. Before fermentation, the cultures were thawed and diluted with $50 \mathrm{~mL}$ sterilized milk (inoculum). Each Schott ${ }^{\circledR}$ flask containing $500 \mathrm{~mL}$ of reconstituted milk was inoculated with $1 \mathrm{~mL}$ of yoghurt starter culture with an average count of 8.2 $\mathrm{Log} \mathrm{CFU} \mathrm{mL} \mathrm{m}^{-1}$ of $\mathrm{St}$ and $5.4 \mathrm{Log} \mathrm{CFU} \mathrm{mL} \mathrm{m}^{-1}$ of $\mathrm{Lb}$ and $1 \mathrm{~mL}$ of probiotic culture with counts around 7.4 $\mathrm{Log} \mathrm{CFU} \mathrm{mL} \mathrm{m}^{-1}(P>0.05)$.

\subsubsection{Experimental procedure}

Eight different fiber-enriched yoghurts were prepared using the four probiotic strains in the two different milk bases, plus eight controls without fiber. The experimental design is presented in Table 4.1.

After inoculation, the flasks with the samples were transferred to water bath equipment assembled to a CINAC (Cynetique d'acidification, Ysebaert, Frépillon, France) system (Spinnler \& Corrieu, 1989), which allows the continuous measurement and recording of $\mathrm{pH}$ and the measurement of the four kinetic parameters considered in this study: (a) the maximum acidification rate $\left(\mathrm{V}_{\max }\right)$, expressed in $10^{-3} \mathrm{pH}$ units per min, (b) the time to reach the maximum acidification rate $\left(\mathrm{T}_{\mathrm{Vmax}}\right)$, (c) the time to reach $\mathrm{pH} 5.0\left(\mathrm{~T}_{\mathrm{pH} 5.0}\right)$, near to the isoelectric point of casein and $(\mathrm{d})$ the time to complete the fermentation $\left(\mathrm{T}_{\mathrm{pH}} 4.5\right)$, all expressed in hours. Two independent batch fermentations were carried out in duplicate on different days at $42^{\circ} \mathrm{C}$ up to $\mathrm{pH} 4.5$.

Once the desired $\mathrm{pH}$ was reached, the fermentation was interrupted by cooling the flasks to $20^{\circ} \mathrm{C}$ in an ice bath, and the fermentation time $\left(\mathrm{T}_{\mathrm{pH} 4.5}\right)$ was recorded. The coagulum was then broken by means of a perforated disk on a stainless steel rod that was moved upwards and downwards for $2 \mathrm{~min}$. The stirred yoghurt was put into $50 \mathrm{~mL}$ polypropylene cups, thermally sealed and stored at $4^{\circ} \mathrm{C}$.

\subsubsection{Total solids, post-acidification and titratable acidity}

Determination of total solids in milk bases and titratable acidity in yoghurts were made according to AOAC (1995). The post-acidification was determined as $\mathrm{pH}$ after 1, 14 and 28 days of cold storage using a pH meter, model Q-400M1 (Quimis, São Paulo, Brazil). The results were expressed as the means of four replicates. 
Table 4.1. Experimental design to evaluate the effect of addition of passion fruit fiber on texture profile and probiotic viability in yogurt made with two types of milk.

\begin{tabular}{|c|c|c|c|}
\hline Microorganisms (probiotic strain) & Milk type & $\begin{array}{l}\text { Passion fruit } \\
\text { fiber }\end{array}$ & $\begin{array}{c}{ }^{*} \text { Probiotic counts } \\
\left(\log \mathrm{CFU} \mathrm{mL} \mathrm{m}^{-1}\right) \text { in the inocula }\end{array}$ \\
\hline *** Y+Lactobacillus acidophilus (L10) & Skim & $\begin{array}{l}- \\
+\end{array}$ & $6.30 \pm 0.19$ \\
\hline & Plain & + & \\
\hline $\mathrm{Y}+$ Lactobacillus acidophilus (NCFM) & $\begin{array}{l}\text { Skim } \\
\text { Plain }\end{array}$ & $\begin{array}{l}- \\
+ \\
- \\
+\end{array}$ & $6.65 \pm 0.22$ \\
\hline $\begin{array}{l}\mathrm{Y}+\text { Bifidobacterium animalis subsp. lactis } \\
(\mathrm{B} 104)\end{array}$ & $\begin{array}{l}\text { Skim } \\
\text { Plain }\end{array}$ & $\begin{array}{l}- \\
+ \\
- \\
+\end{array}$ & $6.44 \pm 0.31$ \\
\hline $\begin{array}{l}\mathrm{Y}+\text { Bifidobacterium animalis subsp. lactis } \\
(\mathrm{HN} 019)\end{array}$ & $\begin{array}{l}\text { Skim } \\
\text { Plain }\end{array}$ & $\begin{array}{l}- \\
+ \\
- \\
+\end{array}$ & $6.40 \pm 0.18$ \\
\hline
\end{tabular}

\subsubsection{Microbiological analyses}

Bacterial enumerations were carried out after 1, 14 and 28 days of cold storage in four replicates of each batch. Samples $(1 \mathrm{~mL})$ were diluted with $0.1 \%$ sterile peptonated water $(9 \mathrm{~mL})$. Afterwards, serial dilutions were carried out, and bacteria were counted, applying the pour plate technique (KODAKA et al., 2005). All media were obtained from Oxoid (Basingstoke, UK). In cocultures, S. thermophilus colonies were enumerated in M17 agar, while those of L. delbrueckii subsp. bulgaricus in MRS ( $\mathrm{pH} 5.4$ ), both under aerobic incubation at $37^{\circ} \mathrm{C}$ for $48 \mathrm{~h}$. The probiotic microorganisms were incubated at $37^{\circ} \mathrm{C}$ for $72 \mathrm{~h}$ under anaerobic conditions provided by AnaeroGen (Oxoid). Enumerations of L. acidophilus were carried out in MRS (pH 6.2) plus $10 \mu \mathrm{L}$ 
$\mathrm{mL}^{-1}$ clindamycin, and Bifidobacterium animalis subsp. lactis in Reinforced Clostridial Agar plus $100 \mu \mathrm{L} \mathrm{mL}^{-1}$ of dicloxacillin. Antibiotics were employed to allow selective growth of the probiotic bacteria. M17 and MRS media (pH 5.4) were prepared according to Jordano et al. (1992) and Dave and Shah (1996), and MRS plus clindamycin according to Lankaputhra and Shah (1996). Cell concentration was expressed as $\mathrm{Log} \mathrm{CFU} \mathrm{mL} \mathrm{mL}^{-1}$ of yoghurt.

\subsubsection{Texture profile}

Texture measurements were carried out as described by Damin et al. (2008). Firmness was determined at $4-6^{\circ} \mathrm{C}$ by penetration tests made with a TA-XT2 texture analyzer (Stable Micro Systems, Godalming, England) on $50 \mathrm{~g}$ packed samples. The probe was a $25 \mathrm{~mm}$ diameter acrylic cylinder, moved at a pretest speed of $5 \mathrm{~mm} . \mathrm{s}^{-1}$, and a test speed of $1 \mathrm{~mm} . \mathrm{s}^{-1}$ through $10 \mathrm{~mm}$ within the sample. The results were expressed as the average of three measurements. Texture properties such as firmness, consistency and cohesiveness were considered. Firmness was measured as the force required to break the structure of yoghurt (RAMCHANDRAN \& SHAH, 2009), consistency as the property by which a material (in this case the yoghurt) resists to a change in shape (DEMAN, 1983) and cohesiveness as the extent to which the yoghurt could be deformed before it ruptures (RAWSON \& MARSHALL, 1997).

\subsubsection{Statistical analyses}

The parameters of experimental yogurts were assessed by General Linear Model ANOVA by using Statistica $8.0^{\circledR}$ software (Statsoft, Tulsa, OK, USA). Different groups were compared by the Tukey test at $P<0.05$, and statistically significant differences among them were indicated by different letters.

\subsection{Results and Discussion}

\subsubsection{Total solid, $\mathrm{pH}$ and kinetics parameters of acidification}

The content of total solids of both plain and skim heat treated milk bases without passion fruit fiber was around $13.04 \pm 0.12 \mathrm{~g} .100 \mathrm{~g}^{-1}$, while with fiber was $14.01 \pm 0.09 \mathrm{~g} .100 \mathrm{~g}^{-1}$. As expected, the presence of fiber increased significantly the total solids content of milk bases (by approximately $1 \%, P<0.05)$. It was also noticed a significant influence on initial $\mathrm{pH}$ that was 6.58 
\pm 0.09 in milk without fiber and $6.42 \pm 0.07$ in milk with fiber $(P<0.05)$, independently of the milk type.

As Table 4.2 shows, the maximum rate of acidification $\left(\mathrm{V}_{\max }\right)$ was significantly reduced $(P$ $<0.05)$ by the addition of passion fruit fiber in both milk types, which can probably be ascribed to the presence of substances with buffering capacity in the passion fruit fiber, such as organic acids and phenolic compounds (ZIBADI \& WATSON, 2004). Furthermore, it was observed that control skim yoghurts co-fermented by Bifidobacterium strains exhibited higher $\mathrm{V}_{\max }$ than the control plain yoghurts co-fermented by the same strains $(P<0.05)$. Nevertheless, the time to reach the maximum acidification rate $\left(\mathrm{T}_{\max }\right)$ was significantly reduced by the presence of the fiber only in plain milk bases and in skims ones co-fermented by lactobacilii. The passion fruit fiber had no effect on the time to reach pH $5.0\left(\mathrm{~T}_{\mathrm{pH} 5.0}\right)$ except for the skim yoghurt co-fermented by L. acidophilus NCFM, in which the fiber reduced this parameter. Moreover, the time to complete fermentation $\left(\mathrm{T}_{\mathrm{pH} 5.0}\right)$ in skim control yoghurts co-fermented by Lactobacillus strains was longer than in plain ones $(P<$ 0.05), thereby indicating a clear effect of the milk type (Table 4.2).

The fermentation lasted from 4.3 to $5.5 \mathrm{~h}$ in plain yoghurts and from 5.3 to $6.8 \mathrm{~h}$ in skim yoghurts. Considering the milk type, in general the fermentation was quicker in plain milk than in skim milk $(P<0.05)$, while the addition of passion fruit fiber significantly accelerated the fermentation in all skim yoghurts, except that performed by B. lactis B104. On the other hand, the fiber had no statistically significant effect on $\mathrm{T}_{\mathrm{pH} 4.5}$ in plain yoghurts $(P>0.05)$. The largest reduction of $\mathrm{T}_{\mathrm{pH}} 4.5(1 \mathrm{~h})$ due to the passion fruit fiber addition was observed in skim yoghurt fermented by $L$. acidophilus NCFM $(P<0.05)$, although no statistically significant difference $(P>$ 0.05), was noticed in the plain yoghurts fermented by the same probiotic strain.

According to Varghese and Mishra (2008), the buffering capacity is directly proportional to the total solids (TS) content of the fermented product, which can lead to longer fermentation time. This observation, which is certainly valid for TS increasing with milk derivatives, does not seem to be applicable to TS increase induced by passion fruit fiber addition that in some cases even accelerated the fermentation (Table 4.2). On the other hand, Almeida et al. (2009) ascribed the different acidification profiles of different LABs to their peculiar capacity to assimilate nutritive compounds of the milk, which could explain the differences in the kinetic parameters observed amongst the various yoghurts. In the present study, the correlation analyses indicates that multiple factors, such as the lipid content of the milk, the culture composition and the presence of passion fruit fiber can affect the acidification parameters. 
Table 4.2. Kinetic parameters of acidification of plain and skim milks fermented by starter co-culture associated with different probiotic strains with and without passion fruit fiber.

\begin{tabular}{|c|c|c|c|c|c|c|}
\hline Milk type & Treatment & Probiotic strain & $\mathrm{V}_{\max }\left(10^{-3} \mathrm{upHmin}^{-1}\right)$ & $\mathbf{T}_{\max }(\mathbf{h})$ & $\mathrm{T}_{\mathrm{pH5.0}}(\mathrm{h})$ & $\mathrm{T}_{\mathrm{pH} 4.5}(\mathrm{~h})$ \\
\hline \multirow[t]{8}{*}{ Skim } & Control & L. acidophilus L10 & $18.36 \pm 0.01^{d}$ & $2.6 \pm 0.01^{\mathrm{d}}$ & $3.35 \pm 0.01^{\mathrm{de}}$ & $6.9 \pm 0.29^{h}$ \\
\hline & \multirow{7}{*}{$\begin{array}{l}\text { With passion } \\
\text { fruit fiber }\end{array}$} & L. acidophilus NCFM & $16.69 \pm 0.02^{c}$ & $2.6 \pm 0.01^{\mathrm{d}}$ & $3.42 \pm 0.00^{\mathrm{e}}$ & $6.6 \pm 0.22^{\mathrm{gh}}$ \\
\hline & & B. lactis $\mathrm{B} 104$ & $22.35 \pm 0.03^{\mathrm{e}}$ & $2.3 \pm 0.00^{\mathrm{bcd}}$ & $2.88 \pm 0.02^{\mathrm{ab}}$ & $5.3 \pm 0.19^{\mathrm{cd}}$ \\
\hline & & B. lactis HN019 & $22.91 \pm 0.02^{\mathrm{e}}$ & $2.3 \pm 0.00^{\mathrm{cd}}$ & $3.02 \pm 0.01^{\mathrm{a}-\mathrm{d}}$ & $6.1 \pm 0.24^{\mathrm{fg}}$ \\
\hline & & L. acidophilus L10 & $13.93 \pm 0.01^{\mathrm{a}}$ & $1.9 \pm 0.00^{\mathrm{abc}}$ & $3.07 \pm 0.03^{\mathrm{bcd}}$ & $6.1 \pm 0.19^{\mathrm{fg}}$ \\
\hline & & L. acidophilus NCFM & $14.49 \pm 0.01^{\mathrm{a}}$ & $1.9 \pm 0.02^{\mathrm{abc}}$ & $3.05 \pm 0.02^{\mathrm{a}-\mathrm{d}}$ & $5.6 \pm 0.19^{\mathrm{ef}}$ \\
\hline & & B. lactis $\mathrm{B} 104$ & $14.02 \pm 0.02^{\mathrm{a}}$ & $2.2 \pm 0.01^{\mathrm{bcd}}$ & $3.02 \pm 0.02^{\mathrm{a}-\mathrm{d}}$ & $5.8 \pm 0.17^{\mathrm{tg}}$ \\
\hline & & B. lactis HN019 & $14.11 \pm 0.02^{\mathrm{a}}$ & $2.6 \pm 0.01^{\mathrm{d}}$ & $2.98 \pm 0.03^{\mathrm{abc}}$ & $5.4 \pm 0.17^{\text {cde }}$ \\
\hline \multirow[t]{8}{*}{ Plain } & Control & L. acidophilus L10 & $17.91 \pm 0.02^{\mathrm{d}}$ & $2.3 \pm 0.01^{\mathrm{cd}}$ & $3.03 \pm 0.03^{\mathrm{abc}}$ & $5.2 \pm 0.16^{\mathrm{bcd}}$ \\
\hline & \multirow{7}{*}{$\begin{array}{l}\text { With passion } \\
\text { fruit fiber }\end{array}$} & L. acidophilus NCFM & $16.63 \pm 0.02^{\mathrm{bc}}$ & $2.3 \pm 0.00^{\mathrm{bcd}}$ & $2.8 \pm 0.04^{\mathrm{ab}}$ & $4.4 \pm 0.23^{\mathrm{ab}}$ \\
\hline & & B. lactis $\mathrm{B} 104$ & $18.73 \pm 0.01^{\mathrm{d}}$ & $2.3 \pm 0.00^{\mathrm{bcd}}$ & $2.87 \pm 0.00^{\mathrm{ab}}$ & $5.0 \pm 0.20^{\mathrm{abc}}$ \\
\hline & & B. lactis HN019 & $17.87 \pm 0.01^{\mathrm{d}}$ & $2.3 \pm 0.04^{\mathrm{bcd}}$ & $2.73 \pm 0.03^{\mathrm{a}}$ & $4.3 \pm 0.25^{\mathrm{a}}$ \\
\hline & & L. acidophilus L10 & $15.66 \pm 0.01^{\mathrm{b}}$ & $1.8 \pm 0.01^{\mathrm{a}}$ & $3.27 \pm 0.01^{\text {cde }}$ & $5.5 \pm 0.29^{\mathrm{def}}$ \\
\hline & & L. acidophilus NCFM & $14.10 \pm 0.01^{\mathrm{a}}$ & $1.8 \pm 0.00^{\mathrm{a}}$ & $3.03 \pm 0.00^{\mathrm{a}-\mathrm{d}}$ & $4.8 \pm 0.18^{\mathrm{abc}}$ \\
\hline & & B. lactis $\mathrm{B} 104$ & $13.90 \pm 0.02^{\mathrm{a}}$ & $1.8 \pm 0.03^{\mathrm{a}}$ & $2.92 \pm 0.03^{\mathrm{ab}}$ & $5.0 \pm 0.27^{\mathrm{abc}}$ \\
\hline & & B. lactis HN019 & $14.57 \pm 0.03^{\mathrm{a}}$ & $1.8 \pm 0.00^{\mathrm{a}}$ & $2.77 \pm 0.05^{\mathrm{ab}}$ & $4.9 \pm 0.21^{\mathrm{abc}}$ \\
\hline
\end{tabular}




\subsubsection{Pos-acidification and titratable acidity}

The results of post-acidification $(\mathrm{pH})$ and titratable acidity during the shelf-life of the yogurts are presented in Table 4.3. After one day of cold storage, the $\mathrm{pH}$ of yoghurts ranged from 4.37 to 4.50 , and the largest differences between the passion fruit fiber yoghurts and the controls were detected in skim yoghurts fermented by L. acidophilus L10 (4.42 fiber yoghurt and 4.50 control) and B. lactis B104 (4.42 fiber yoghurt and 4.48 control) $(P<0.05)$. Titratable acidity varied from 0.64 to $0.74 \mathrm{mg}$ lactic acid $\mathrm{g}^{-1}$ in plain yoghurts and from 0.87 to $1.07 \mathrm{mg}$ lactic acid $\mathrm{g}^{-1}$ in skim yoghurts. The increase in this parameter induced by the addition of passion fruit fiber was statistically significant in all yoghurts $(P<0.05)$, but the plain ones co-fermented by $B$. lactis strains.

After 14 days of shelf-life the $\mathrm{pH}$ of all yoghurts decreased significantly $(P<0.05)$ and ranged from 4.21 to 4.38 amongst the plain yoghurts and from 4.26 to 4.38 amongst the skim ones. On the other hand, after 28 days, it was observed a slight but significant increase in the average $\mathrm{pH}$ of control plain yoghurts co-fermented by L. acidophilus NCFM and B. lactis strains and passion fruit fiber plain yoghurts co-fermented by L. acidophilus strains and B. lactis B104 $(P<0.05)$. Surprisingly all the passion fruit fiber plain yoghurts showed higher $\mathrm{pH}$ than their respective controls $(P<0.05)$. However, such a scenario did in not happen within the skim yoghurts group. In this case the fiber did in fact promote a significant decrease in the $\mathrm{pH}$ of all yoghurts, except that co-fermented by B. lactis B104. A possible explanation of this dual behavior could be the simultaneous occurrence of fatty acid consumption as carbon source after sugar depletion and fiber pectin degradation to uronic acids. Prevalence of the former activity in plain yoghurts was likely responsible for alkalinization, whereas its absence in skim yoghurts led to acidification.

After 14 days of shelf-life all plain yoghurts exhibited a significant increase in their titratable acidity, but they still had lower acidity level compared with the skim yoghurts $(P<0.05)$. At 14 and 28 days the highest values of average titratable acidity were observed in passion fruit fiber skim yoghurts $(P<0.05)$.

Considering the plain period of shelf life, it was observed that the average titratable acidity in yoghurts containing passion fruit fiber was significantly higher than in their respective controls, and that in skim yoghurts higher than in the plain ones $(P<0.05)$. As far as the probiotic cultures is concerned, in general, the yoghurts co-fermented by L. acidophilus strains exhibited lower titratable acidity than those co-fermented by $B$. lactis strains $(P<0.05)$. Such a behavior should be indeed expected by the fact that the homolactic metabolism of the former leads to two lactic acid moles per 
mole of glucose consumed, while that of bifidobacteria to one mol of lactic acid and 1.5 moles of acetic acid.

Table 4.3. Post-acidification $(\mathrm{pH})$ and titratable acidity during shelf-life of control and passion fruit fiber yogurts.

\begin{tabular}{|c|c|c|c|c|c|c|c|c|}
\hline \multicolumn{3}{|c|}{ Yoghurts } & \multicolumn{3}{|c|}{$\mathbf{p} \mathbf{H}^{*}$} & \multicolumn{3}{|c|}{ Titratable acidity ( $\%$ lactic acid) * } \\
\hline $\begin{array}{l}\text { Milk } \\
\text { type }\end{array}$ & Treatment & Probiotic strain & d 1 & d 14 & d 28 & d 1 & d 14 & d 28 \\
\hline \multirow[t]{8}{*}{ Skim } & Control & La L10 & $4.50^{x}$ & $4.38^{\mathrm{opqr}}$ & $4.40^{\mathrm{pqrs}}$ & $0.87^{\mathrm{ij}}$ & $0.95^{\mathrm{k}}$ & $0.96^{k}$ \\
\hline & & La NCFM & $4.43^{\text {stu }}$ & $4.34^{\mathrm{klm}}$ & $4.40^{\mathrm{pqrs}}$ & $0.90^{\mathrm{j}}$ & $0.98^{\mathrm{kl}}$ & $1.02^{\operatorname{lmn}}$ \\
\hline & & B104 & $4.48^{\mathrm{vx}}$ & $4.32^{\text {hijk }}$ & $4.34^{\operatorname{lmn}}$ & $0.96^{\mathrm{k}}$ & $0.98^{\mathrm{kl}}$ & $1.18^{\mathrm{st}}$ \\
\hline & & B1 HN019 & $4.43^{\text {tu }}$ & $4.28^{\text {efg }}$ & $4.39^{\mathrm{pqr}}$ & $0.95^{\mathrm{k}}$ & $0.99^{\mathrm{klm}}$ & $1.14^{\mathrm{rs}}$ \\
\hline & With passion & La L10 & $4.43^{\text {stu }}$ & $4.26^{\mathrm{bcd}}$ & $4.33^{\text {hijk }}$ & $0.97^{\mathrm{k}}$ & $1.09^{\mathrm{pq}}$ & $1.10^{\mathrm{pq}}$ \\
\hline & fruit fiber & La NCFM & $4.45^{\text {tuv }}$ & $4.30^{\text {ghi }}$ & $4.34^{\mathrm{jklm}}$ & $0.97^{\mathrm{k}}$ & $1.04^{\text {no }}$ & $1.08^{\mathrm{op}}$ \\
\hline & & $\mathrm{B} 104$ & $4.42^{\text {stu }}$ & $4.29^{\mathrm{efg}}$ & $4.34^{\mathrm{jklm}}$ & $1.07^{\text {nop }}$ & $1.10^{\mathrm{pq}}$ & $1.22^{\mathrm{tu}}$ \\
\hline & & Bl HN019 & $4.47^{\mathrm{uvx}}$ & $4.30^{\mathrm{fgh}}$ & $4.32^{\text {hij }}$ & $1.04^{\mathrm{mn}}$ & $1.08^{\mathrm{op}}$ & $1.25^{\mathrm{u}}$ \\
\hline \multirow[t]{8}{*}{ Plain } & Control & La L10 & $4.39^{\mathrm{opqr}}$ & $4.23^{\mathrm{ab}}$ & $4.23^{\mathrm{abc}}$ & $0.66^{\mathrm{a}}$ & $0.77^{\text {efg }}$ & $0.74^{\mathrm{de}}$ \\
\hline & & La NCFM & $4.42^{\mathrm{rst}}$ & $4.21^{\mathrm{a}}$ & $4.22^{a b}$ & $0.65^{a}$ & $0.78^{\mathrm{gh}}$ & $0.76^{\text {ef }}$ \\
\hline & & B104 & $4.37^{\operatorname{lmn}}$ & $4.24^{\mathrm{abc}}$ & $4.22^{\mathrm{ab}}$ & $0.67^{\mathrm{ab}}$ & $0.76^{\text {ef }}$ & $0.76^{\text {ed }}$ \\
\hline & & B1 HN019 & $4.44^{\text {tuv }}$ & $4.28^{\mathrm{efg}}$ & $4.26^{\text {cde }}$ & $0.64^{\mathrm{a}}$ & $0.72^{\mathrm{cd}}$ & $0.73^{\mathrm{cd}}$ \\
\hline & With passion & La L10 & $4.37^{\operatorname{lmno}}$ & $4.29^{\mathrm{fgh}}$ & $4.32^{\text {fghi }}$ & $0.68^{a}$ & $0.74^{\mathrm{de}}$ & $0.74^{\mathrm{de}}$ \\
\hline & fruit fiber & La NCFM & $4.46^{\mathrm{uv}}$ & $4.35^{\operatorname{lmno}}$ & $4.38^{\text {nop }}$ & $0.65^{\mathrm{ab}}$ & $0.74^{\mathrm{de}}$ & $0.70^{\mathrm{bc}}$ \\
\hline & & B104 & $4.41^{\mathrm{rst}}$ & $4.32^{\text {fghi }}$ & $4.31^{\text {ghij }}$ & $0.75^{\text {def }}$ & $0.80^{\mathrm{hi}}$ & $0.78^{\text {ghi }}$ \\
\hline & & B1 HN019 & $4.42^{\text {stu }}$ & $4.34^{\mathrm{klm}}$ & $4.33^{\mathrm{ijkl}}$ & $0.72^{\mathrm{cd}}$ & $0.80^{\mathrm{hi}}$ & $0.77^{\mathrm{efg}}$ \\
\hline
\end{tabular}

* Standard deviations were under 0.05. Means $(\mathrm{N}=4)$ with different letters in the same column are significantly different $(P<0.05)$. Abbreviations: d1, d14 and d28 = days 1, 14 and 28 after fermentation. La NCFM and LaL10, $L$. acidophilus strains NCFM and L10; B1 HN019 and B104, B. animalis subsp. lactis strains HN019 and B104. 


\subsubsection{Microorganisms viability}

During the plain shelf-life, S. thermophilus counts were stable and ranged, as an average, from 8.6 to 10.9 Log CFU mL ${ }^{-1}$ (Figure 4.1). In the period between 1 and 14 days, a mild but significant decrease in St counts occurred in all yoghurts co-fermented by L. acidophilus strains, but an increase in skim yoghurts co-fermented by B. lactis strains $(P<0.05)$.

In contrast with St counts invariability during shelf-life, L. delbrueckii subsp. bulgaricus suffered a large decrease in its counts, which ranged from 6.2 to 9.5 and from 2.9 to $7.1 \mathrm{Log}$ CFU $\mathrm{mL}^{-1}$ after 1 and 28 days, respectively (Figure 4.2). At the end of the plain shelf-life, the highest counts of Lb were observed in yoghurts co-fermented by L. acidophilus strains, particularly the L10 one $(P<0.05)$. Such a synbiotic effect of $L$. acidophilus L10 on Lb was previously noticed by Espirito Santo et al (2010).

At the $1^{\text {st }}$ day of cold storage, the probiotic counts varied from 8.5 to $10.8 \mathrm{Log}_{\mathrm{CFU} \mathrm{mL}}{ }^{-1}$ in yoghurts co-fermented by L. acidophilus strains and from 7.9 to $9.9 \mathrm{Log}_{\mathrm{CFU} \mathrm{mL}}^{-1}$ by B. lactis strains (Figure 4.3). Amongst the skim yoghurts, the counts of L. acidophilus were about $1 \mathrm{Log}$ higher than those of B. lactis $(P<0.05)$ in spite of the same counts of both probiotic species in the inocula. Regarding the control, a beneficial effect of passion fruit fiber was observed only in $B$. lactis B104 counts in skim yoghurt, but the contrary took place in plain yoghurt $(P<0.05)$.

A dramatic change in the probiotic counts profile in skim yoghurts occurred after 14 days of shelf-life. The counts of $B$. lactis raised by $1.5 \mathrm{Log}$ as an average and were significantly higher than the ones of L. acidophilus that decreased by about $2 \log (P<0.05)$. Furthermore, the passion fruit fiber had a beneficial effect on the counts of $B$. lactis strains in skim yoghurts and those of $B$. lactis HN019 in plain yoghurt $(P<0.05)$, the only negative effect of the fiber being detected in the counts of L. acidophilus NCFM in plain yoghurts $(P<0.05)$ (Figure 4.3$)$.

At the end of shelf-life, the counts of the probiotic strains ranged, as a plain, from 6.4 to 8.9 Log CFU mL $\mathrm{m}^{-1}$, being higher in skim yoghurts except for L. acidophilus $\mathrm{L} 10$ on which no effect due to milk type was observed. The passion fruit fiber did not promote any significant variation in the probiotic counts, except in that of B. lactis B104 in plain yoghurt that was 0.8 Log higher than its control. 


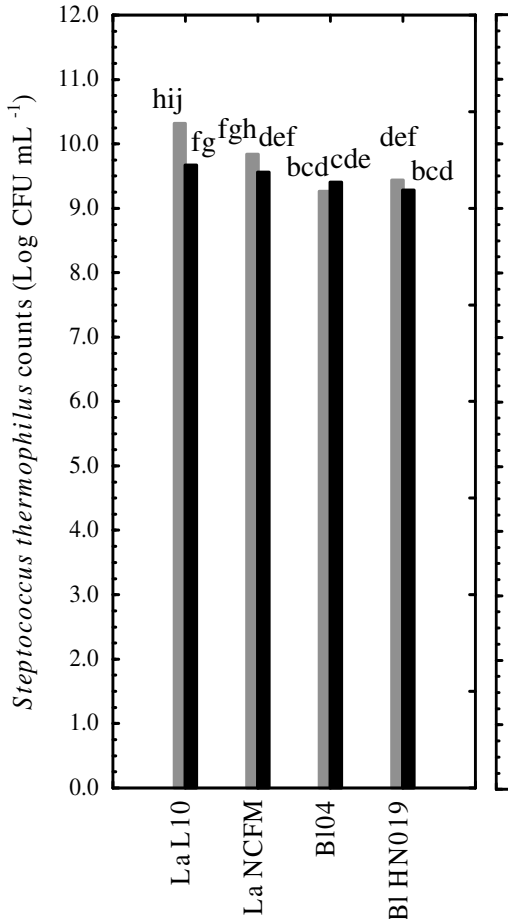

d 1

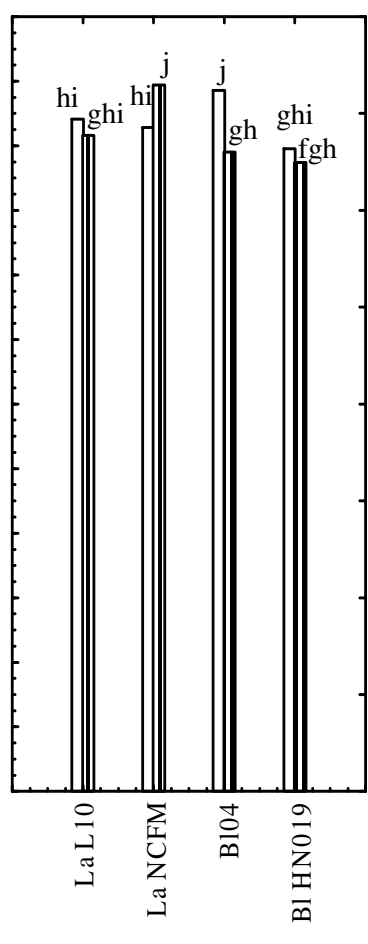

d 14

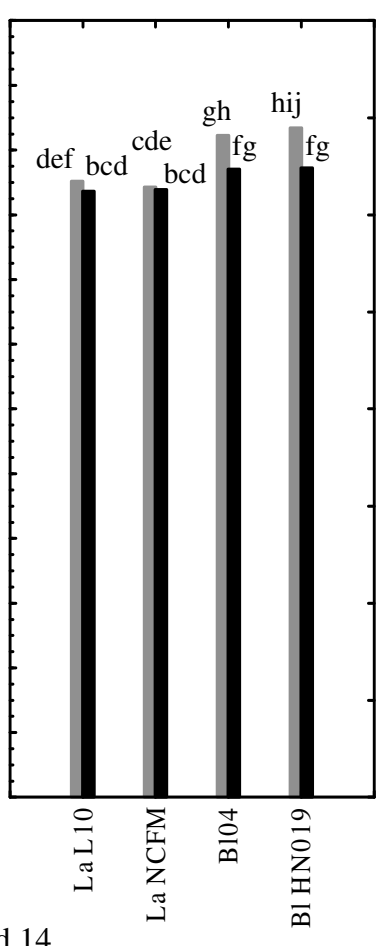

Passion fruit fiber skim yoghurt
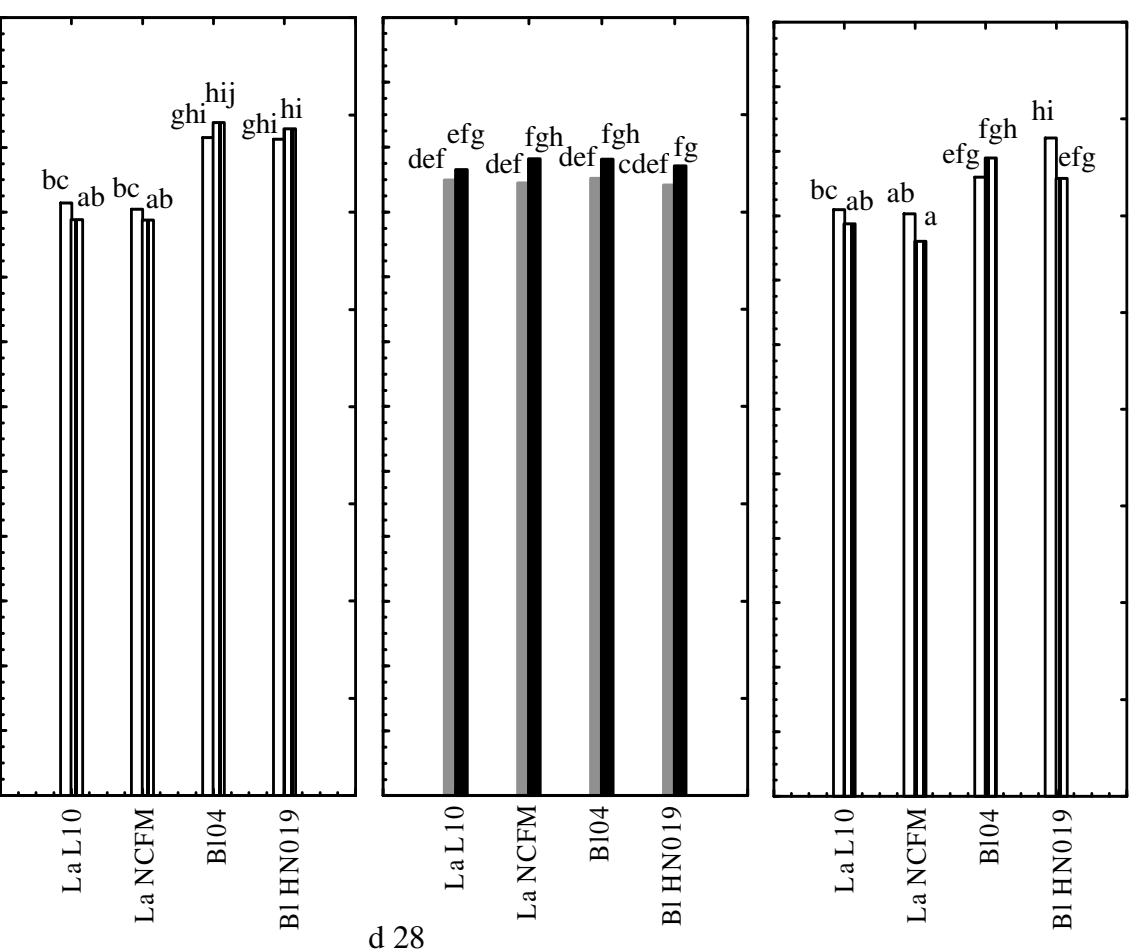

Control whole yoghurt

[I] I] Passion fruit fiber whole yoghurt

Figure 4.1. Streptococcus thermophilus counts in control and fiber yoghurts co-fermented by different probiotic strains.

Abbreviations: B104, HN019, B94 = yoghurts co-fermented by B. animalis subsp. lactis B104, HN019 and B94, respectively; L10 = yoghurts co-fermented by L. acidophilus L10. d1, d14 and d28 = days 1, 14 and 28 after fermentation. Means with different letters are significantly different $(P<0.05) . N=64$. 

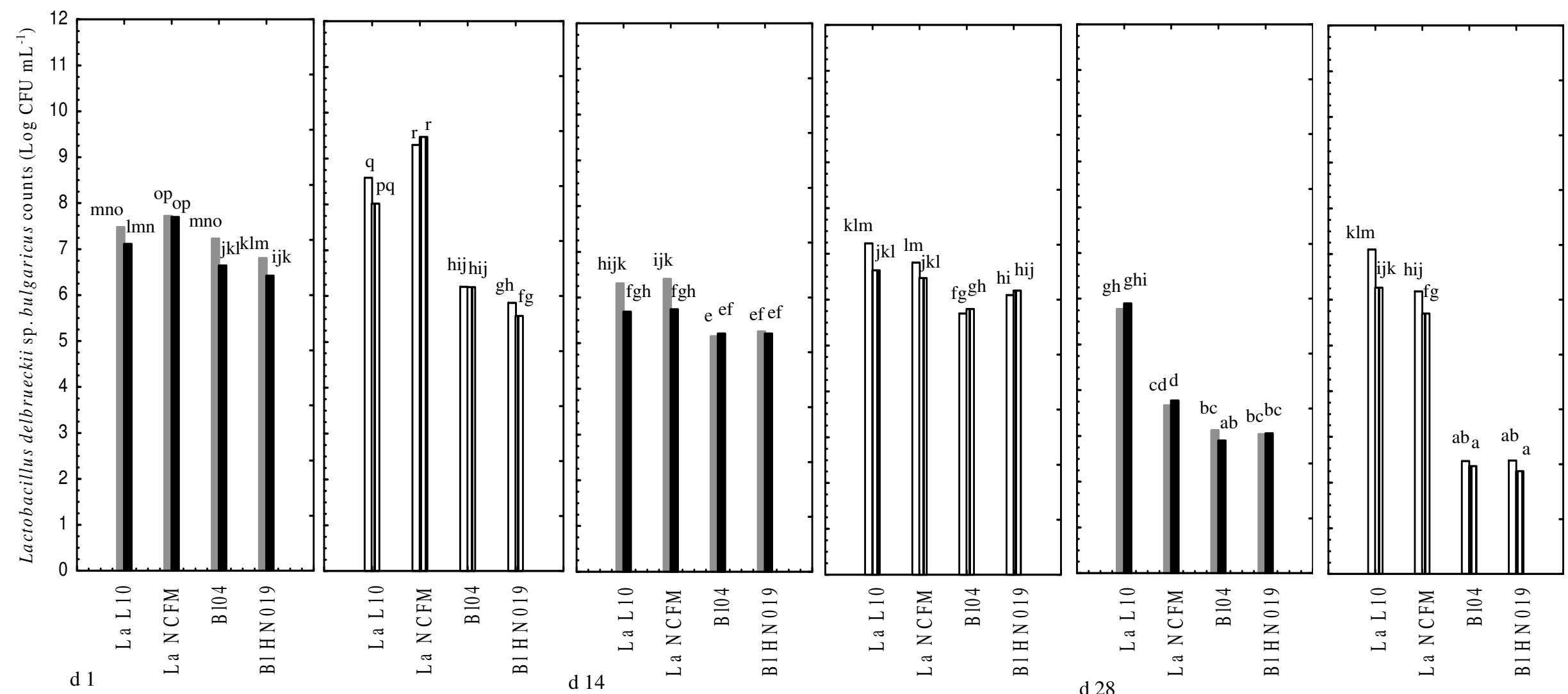

Control skim yoghurt

Passion fruit fiber skim yoghurt

Control whole yoghurt

Figure 4.2. Lactobacillus delbrueckii subsp. bulgaricus counts in control and fiber yoghurts co-fermented by different probiotic strains.

Abbreviations: B104, HN019, B94 = yoghurts co-fermented by B. animalis subsp. lactis B104, HN019 and B94, respectively; L10 = yoghurts co-fermented by L. acidophilus L10. $\mathrm{d} 1, \mathrm{~d} 14$ and $\mathrm{d} 28=$ days 1,14 and 28 after fermentation. Means with different letters are significantly different $(P<0.05) . N=64$. 

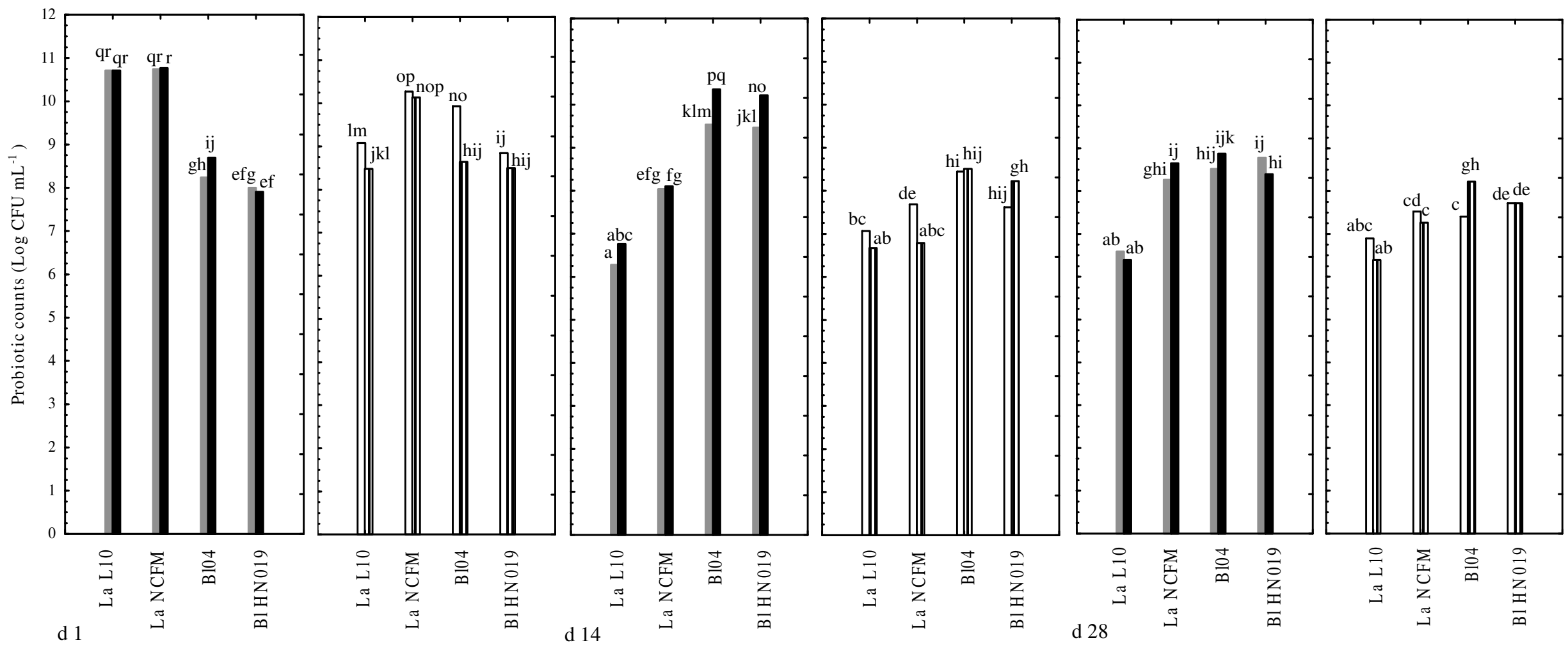

Control skim yoghurt

Passion fruit fiber skim yoghurt

Control plain yoghurt

而而 Passion fruit fiber plain yoghurt

Figure 4.3. Probiotic counts in control and fiber yoghurts co-fermented by different probiotic strains.

Abbreviations: B104, HN019, B94 = yoghurts co-fermented by B. animalis subsp. lactis B104, HN019 and B94, respectively; L10 = yoghurts co-fermented by L. acidophilus L10. d1, d14 and d28 = days 1, 14 and 28 after fermentation. Means with different letters are significantly different $(P<0.05) . N=16$. 
Talcott et al. (2003) and Narain et al. (2004) reported that some compounds of passion fruit, such as phenolic compounds, fatty acid esters, thiols, terpenes and alcohols can inhibit the growth of L. acidophilus. According to a study of Vinderola et al. (2002), the strawberry, pineapple and kiwi juices did not influence the growth of $L$. acidophilus when the juices were previously neutralized. Likewise, the initial $\mathrm{pH}$ of the milk containing passion fruit fiber - which was near the neutrality ( $\mathrm{pH}$ 6.42) - may have attenuated the possible negative effect of the acidity from the fruit on the viability of L. acidophilus and B. lactis strains tested. Besides, the concentration of passion fruit fiber may not have been enough to exert an inhibitory effect on the probiotics, with exception of the NCFM strain on the $14^{\text {th }}$ day.

\subsubsection{Texture profile}

The texture profiles of the different yoghurts evaluated after 1, 14 and 28 days of cold storage are shown in Table 4.4.

Regarding only the influence of the milk type, during the cold storage the plain control yoghurts co-fermented by lactobacilii showed higher firmness, consistency and cohesiveness than the respective skim ones $(P<0.05)$. This observation is supported by some studies that pointed out that a reduction in fat content can cause a fragile texture due to weaker network of the protein gel in yoghurts (GUVEN et al., 2005; RAMCHANDRAN \& SHAH, 2009). As far as the influence of passion fruit fiber is concerned, it promoted, as an average, higher values of all texture parameters in skim yoghurts co-fermented by $B$. lactis strains compared to their respective controls or to plain fiber yoghurts $(P<0.05)$. Meanwhile, it reduced significantly the firmness and consistency, but not the cohesiveness, of plain yoghurts co-fermented by L. acidophilus L10.

As expected, in general, all texture parameters significantly increased during cold storage, being the most marked increase observed after 1 and 14 days. At the end of storage, firmness and consistency in all passion fruit fiber skim yoghurts were higher than in their respective controls, except when using L. acidophilus NCFM as probiotic, while their cohesiveness was increased by the addition of fiber in all cases. As regards the plain yoghurts, firmness was higher in controls cofermented by $L$. acidophilus NCFM and B. lactis strains $(P<0.05)$, while consistency and cohesiveness were significantly higher in the same yoghurts but that co-fermented by B. lactis B104. 
Table 4.4. Texture parameters of plain and skim yogurts co-fermented by different probiotic strains and with or without passion fruit fiber

\begin{tabular}{|c|c|c|c|c|c|c|c|c|c|c|c|}
\hline \multicolumn{3}{|c|}{ Yoghurts } & \multicolumn{3}{|c|}{ Firmness (N) } & \multicolumn{3}{|c|}{ Consistency (N.s) } & \multicolumn{3}{|c|}{ Cohesiveness (N) } \\
\hline $\begin{array}{l}\text { Milk } \\
\text { type }\end{array}$ & Treatment & Probiotic & d 1 & d 14 & d 28 & d 1 & d 14 & d 28 & d 1 & d 14 & d 28 \\
\hline \multirow[t]{8}{*}{ Skim } & Control & La L10 & $0.25^{\mathrm{a}}$ & $0.28^{a b}$ & $0.37^{\mathrm{cd}}$ & $2.06^{a b}$ & $2.19^{b c}$ & $2.60^{\mathrm{cd}}$ & $0.16^{\mathrm{a}}$ & $0.22^{a b}$ & $0.23^{a b}$ \\
\hline & & La NCFM & $0.25^{\mathrm{a}}$ & $0.31^{b c}$ & $0.35^{\text {cd }}$ & $1.95^{\mathrm{a}}$ & $2.56^{\mathrm{c}}$ & $2.69^{\mathrm{cd}}$ & $0.19^{\mathrm{a}}$ & $0.25^{\mathrm{abc}}$ & $0.24^{\mathrm{c}}$ \\
\hline & & $\mathrm{B} 104$ & $0.27^{\mathrm{ab}}$ & $0.36^{\mathrm{cd}}$ & $0.39^{\text {cde }}$ & $2.22^{\mathrm{abc}}$ & $2.70^{\mathrm{d}}$ & $2.90^{\mathrm{de}}$ & $0.22^{\mathrm{ab}}$ & $0.27^{\mathrm{bc}}$ & $0.26^{\mathrm{bc}}$ \\
\hline & & B1 HN019 & $0.27^{\mathrm{bc}}$ & $0.41^{\mathrm{de}}$ & $0.37^{\mathrm{cd}}$ & $2.56^{\mathrm{c}}$ & $3.08^{\mathrm{de}}$ & $2.82^{\text {cde }}$ & $0.25^{\mathrm{abcd}}$ & $0.30^{\mathrm{cd}}$ & $0.26^{\mathrm{bc}}$ \\
\hline & With passion & La L10 & $0.37^{\mathrm{d}}$ & $0.45^{\text {efg }}$ & $0.48^{\mathrm{fg}}$ & $2.95^{\mathrm{de}}$ & $3.50^{\mathrm{f}}$ & $3.51^{\mathrm{f}}$ & $0.31^{\text {cde }}$ & $0.36^{\text {def }}$ & $0.38^{\mathrm{efg}}$ \\
\hline & fruit fiber & La NCFM & $0.27^{\mathrm{ab}}$ & $0.38^{\mathrm{cd}}$ & $0.38^{\text {cde }}$ & $2.15^{\mathrm{ab}}$ & $2.94^{\mathrm{e}}$ & $2.94^{\mathrm{e}}$ & $0.22^{\mathrm{ab}}$ & $0.31^{\text {cde }}$ & $0.30^{\mathrm{cd}}$ \\
\hline & & $\mathrm{B} 104$ & $0.43^{\mathrm{e}}$ & $0.50^{g}$ & $0.48^{\mathrm{fg}}$ & $3.39^{\text {ef }}$ & $3.82^{g}$ & $3.58^{f}$ & $0.36^{\mathrm{e}}$ & $0.40^{\mathrm{g}}$ & $0.37^{\text {ef }}$ \\
\hline & & Bl HN019 & $0.37^{\mathrm{d}}$ & $0.48^{\mathrm{fg}}$ & $0.48^{\mathrm{fg}}$ & $3.49^{\mathrm{f}}$ & $3.97^{\mathrm{gh}}$ & $3.50^{f}$ & $0.32^{\text {de }}$ & $0.38^{\text {efg }}$ & $0.36^{\mathrm{det}}$ \\
\hline \multirow[t]{8}{*}{$\overline{\text { Plain }}$} & Control & La L10 & $0.34^{\mathrm{cd}}$ & $0.45^{\text {ef }}$ & $0.44^{\text {ef }}$ & $2.86^{\text {cde }}$ & $3.55^{f}$ & $3.53^{f}$ & $0.28^{b c}$ & $0.31^{\text {cde }}$ & $0.32^{\mathrm{de}}$ \\
\hline & & La NCFM & $0.31^{\mathrm{bc}}$ & $0.49^{\mathrm{fg}}$ & $0.52^{\mathrm{g}}$ & $2.63^{\mathrm{cd}}$ & $4.06^{\mathrm{gh}}$ & $4.18^{\mathrm{h}}$ & $0.26^{\mathrm{bc}}$ & $0.35^{\text {def }}$ & $0.37^{\text {ef }}$ \\
\hline & & $\mathrm{B} 104$ & $0.28^{\mathrm{abc}}$ & $0.31^{\mathrm{bc}}$ & $0.49^{\mathrm{fg}}$ & $2.23^{\mathrm{bc}}$ & $2.39^{\mathrm{bcd}}$ & $3.05^{\mathrm{de}}$ & $0.23^{\mathrm{ab}}$ & $0.21^{\mathrm{ab}}$ & $0.29^{\mathrm{cd}}$ \\
\hline & & B1 HN019 & $0.26^{\mathrm{ab}}$ & $0.32^{\mathrm{bc}}$ & $0.51^{\mathrm{g}}$ & $2.11^{\mathrm{ab}}$ & $2.35^{\mathrm{bcd}}$ & $3.28^{\text {ef }}$ & $0.21^{\mathrm{ab}}$ & $0.20^{\mathrm{a}}$ & $0.36^{\mathrm{det}}$ \\
\hline & With passion & La L10 & $0.24^{\mathrm{a}}$ & $0.39^{\text {de }}$ & $0.51^{\mathrm{g}}$ & $1.59^{\mathrm{a}}$ & $2.58^{\mathrm{cd}}$ & $3.28^{\text {ef }}$ & $0.22^{\mathrm{ab}}$ & $0.24^{\mathrm{abc}}$ & $0.36^{\text {det }}$ \\
\hline & fruit fiber & La NCFM & $0.28^{\mathrm{abc}}$ & $0.40^{\mathrm{de}}$ & $0.47^{\text {efg }}$ & $1.50^{\mathrm{a}}$ & $2.86^{\mathrm{cde}}$ & $3.05^{\mathrm{de}}$ & $0.26^{\mathrm{bc}}$ & $0.27^{\mathrm{bc}}$ & $0.29^{\mathrm{cd}}$ \\
\hline & & $\mathrm{B} 104$ & $0.28^{\mathrm{ab}}$ & $0.38^{\mathrm{de}}$ & $0.37^{\mathrm{cd}}$ & $2.11^{\mathrm{ab}}$ & $2.82^{\text {cde }}$ & $2.72^{\mathrm{d}}$ & $0.23^{\mathrm{ab}}$ & $0.28^{\mathrm{bc}}$ & $0.29^{\mathrm{bcc}}$ \\
\hline & & B1 HN019 & $0.28^{\mathrm{abc}}$ & $0.38^{\mathrm{de}}$ & $0.38^{\text {cde }}$ & $2.15^{\mathrm{ab}}$ & $2.61^{\mathrm{cd}}$ & $2.79^{\mathrm{de}}$ & $0.23^{\mathrm{ab}}$ & $0.26^{\mathrm{bc}}$ & $0.27^{\mathrm{bc}}$ \\
\hline
\end{tabular}

Means with different letters in the same column are significantly different $(P<0.05) . N=12$. All standard deviations were under $5 \%$ of the average and are not shown.

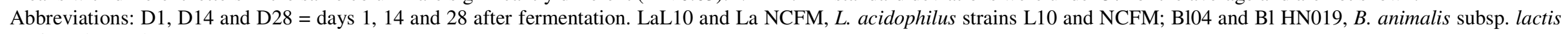
strains B104 and HN019. 
According to Damin et al. (2008), the firmness is higher in yoghurts lasting longer fermentation time. However, in the present study skim yoghurts co-fermented by lactobacilli - in spite of the longer fermentation time - did not show any firmness increase after 1 day of cold storage compared to the other treatments.

Cultures of lactic acid bacteria producer of exopolysaccharides (EPS) have been used to improve the texture of yoghurts (WELMAN \& MADDOX, 2003; SODINI et al., 2004). However, the high counts of EPS-producing L. acidophilus and S. thermophilus in skim yoghurts did not correspond to any increase in their textural parameters. This observation can be explained with the formation of a few weak polysaccharide-protein interactions instead of more stable protein-protein ones (FOLKENBERG et al., 2006; RAMCHANDRAN \& SHAH, 2009), which may have contributed to lowering the firmness of yoghurts.

The results of the present study taken together suggest that the textural parameters were influenced by a combination of factors such as culture composition, milk type and passion fruit fiber addition, which justifies further efforts in this field.

\subsection{Conclusions}

The effects of milk type and passion fruit fiber addition on the kinetic and texture parameters, post-acidification and microorganisms counts were investigated in yoghurts cofermented by a common starter culture and one of the following probiotics, Lactobacillus acidophilus (strains L10 and NCFM) and Bifidobacterium animalis subsp. lactis (strains B104 and HN019). The most remarkable findings of this study are:

- the passion fruit fiber reduced significantly the maximum acidification rate in both skim and plain milks and accelerated the fermentation in all skim yoghurts, except the one co-fermented by B. lactis $\mathrm{B} 104$;

- the titratable acidity was higher in passion fruit fiber yoghurts and in skim control yoghurts;

- L. acidophilus strains exerted a synbiotic effect on L. delbrueckii subsp. bulgaricus;

- contrary to the milk type, the passion fruit fiber did not show any clear effect on probiotic counts during the shelf-life;

- the addition of passion fruit fiber increased the cohesiveness of all probiotic skim yoghurts at the end of shelf-life. 


\section{CONCLUSÕES}

Este estudo traz evidências inéditas, entre elas as principais são:

O efeito prebiótico da polpa de açaí sobre a viabilidade de L. acidophilus L10, Bifidobacterium animalis subsp. lactis B104 e B. longum B105 em iogurtes na quarta semana de armazenamento refrigerado;

A polpa de açaí combinada a Lactobacillus acidophilus L10, B. lactis Bifidobacterium B104 ou B94, age sinergisticamente sobre a viabilidade de Streptococcus thermophilus nos iogurtes;

As fibras de maçã e banana exerceram um efeito prebiótico em todas as cepas testadas: $L$. acidophilus L10 e B. lactis B104, HN019 e B94;

Tanto a polpa de açaí quanto as fibras dietéticas totais de maçã, banana ou maracujá estimularam a produção de ácidos graxos poliinsaturados e os de cadeia curta e reduziram o teor dos saturados em relação aos respectivos controles, tornando mais saudável a fração lipídica dos iogurtes;

A combinação de adição de polpa de açaí e algumas cepas probióticas, particularmente de $B$. lactis cepas B104 e B94, aumenta a produção de ácido linoleico conjugado (CLA) nos iogurtes;

As fibras de maracujá estimularam a produção de CLA e promoveram a coesividade de todos os iogurtes desnatados.

Em suma, os resultados apontam a aplicabilidade tanto do uso da polpa de açaí quanto das fibras dietéticas totais dos subprodutos da maçã, banana e maracujá como ingredientes capazes de melhorar o perfil lipídico de iogurtes desnatados, o que leva à formulação de um produto alimentar com elevado valor agregado, seja do ponto de vista da saúde do consumidor, quanto do ponto de vista ambiental.

Através desta tese surgiram questões que constituem oportunidades para estudos futuros, tais como:

Elucidar os compostos presentes no açaí e na fibra de maracujá capazes de estimular a produção de CLA e outros ácidos graxos poliinsaturados pelos micoorganismos testados, especialmente por $B$. lactis cepas B104 e B94;

Determinar os fatores presentes na polpa de açaí responsáveis por estimular especificamente a viabilidade de L. acidophilus L10, B. lactis B104 e B. longum B105 na quarta semana de armazenamento a frio;

De modo semelhante, avaliar os fatores presentes nas fibras de maçã e de banana capazes de estimular a viabilidade de L. acidophilus L10, B. lactis B104, B94 e HN019. 


\section{CONCLUSIONS}

The main conclusions of this study are:

The açaí pulp presented a prebiotic effect on the viability of L. acidophilus L10, B. lactis B104 and B. longum B105 in yoghurt at 4 weeks of storage;

The acai pulp in combination with Lactobacillus acidophilus L10, B. lactis B104 or B94 act synergistically on the viability of Streptococcus thermophilus;

The prebiotic effect was also observed in apple and banana fibers on the viability of L. acidophilus L10 and strains of B. lactis B104, HN019 and B94;

Both açaí pulp and total dietary fiber of apple, banana and passion fruit added into milk, stimulated the production of polyunsaturated and short chain fatty acids and reduced the content of saturated ones in yoghurts in respect to their controls, making healthier the lipid fraction of the yogurt;

Besides, the combination of acai pulp and some probiotic strains, particularly B. lactis B104 and B94 increases the production of conjugated linoleic acid (CLA) in yogurt;

The passion fruit fibers stimulated the production of CLA and promoted the cohesiveness in all skim yoghurt.

In sum, the results show the applicability of both the acai pulp and the total dietary fiber from by-products of apple, banana and passion fruit as ingredients that can improve the lipid profile of yoghurt, which can lead to formulations of high value added food products, from both the consumer health and the environmental points of view.

Through this thesis some questions that arisen constitute opportunities for future studies such as:

Elucidate the compounds present in the açaí and passion fruit fiber that are able to stimulate the production of CLA and other polyunsaturated fatty acids by the micoorganisms tested, especially by B. lactis strains B104 and B94;

Determine the factors present in the açaí yoghurts specifically responsible for stimulating the viability of L. acidophilus L10, B. lactis B104 and B. longum B105 in the fourth week of cold storage;

Similarly, assess the factors present in the apple and banana fibers that stimulate the viability of $L$. acidophilus L10, B. lactis B104, B94 and HN019. 


\section{REFERENCES}

AMERICAN ASSOCIATION OF CEREAL CHEMISTS (AACC). Official method 30-25, 46-13 and 08-01. Approved Methods of the AACC. St. Paul, MN, USA, 2000.

ACKMAN, R.G. Application of gas-liquid chromatography to lipid separation and analysis: qualitative and quantitative analysis. In: C.K. CHOW (Ed), Fatty acid in foods and their health implications, 3 ed, pp. 47-62. Boca Raton, FL, USA: CRC Press, 2007.

ADOLFSSON, O.; MEYDANI, S. N.; RUSSELL, R. M. Yogurt and gut function. American Journal of Clinical Nutrition, v. 80, p. 245 - 256, 2004.

AGÊNCIA NACIONAL DE VIGILÂNCIA SANITÁRIA. Alimentos com alegações de propriedades funcionais e ou de saúde, novos alimentos/ingredientes, substânciasbioativas e probióticos: lista de alegações de propriedade funcional aprovadas. Atualizado em agosto, 2007. Disponível em: http://www.anvisa.gov.br/alimentos/comissoes/tecno_lista_alega.htm. Acesso em: março de 2009.

AKALIN, A. S.; TOKUSOGLU, O.; GONC, S.; AYCAN, S. Occurrence of conjugated linoleic acid in probiotic yoghurts supplemented with fructooligosaccharide. International Dairy Journal, v. 17, p. 1089-1095, 2007.

ALEGRE, I.; VINAS, I.; USALL, J.; ANGUERA, M.; ABADIAS, M. Microbiological and physicochemical quality of fresh-cut apple enriched with the probiotic strain Lactobacillus rhamnosus GG. Food Microbiology, v. 28 (1), p. 59 - 66, 2011.

ALMEIDA, K.E.; TAMIME, A.Y.; OLIVEIRA, M.N. Influence of total solids contents of milk whey on the acidifying profile and viability of various lactic acid bacteria. LWT - Food Science and Technology, 42, p. 672-678, 2009.

ALMEIDA, M.H.B.; SZOELLNER, S.S.; CRUZ, A.G.; MOURA, M.R.L.; CARVALHO, L.M.J. FREITAS, M.C.J.; SANTÁNA, A. Potentially probiotic açai yogurt. International Journal of Dairy Technology, v. 61, p. 178-182, 2008.

ALONSO, L.; CUESTA, E. P.; GILLILAND, S. E. Production of free conjugated linoleic acid by Lactobacillus acidophilus and Lactobacillus casei of human intestinal origin. Journal of Dairy Science, v. 86, p. 1941-1946, 2003.

AOAC Fat, lactose, protein and solids in milk. Official Methods of Analysis. AOAC Official Method 972.16. Washington, DC, USA: Association of Official Analytical Chemists, 1995. 
AOAC (1999). Official method 985.29. Washington, DC, USA: Association of Official Analytical Chemists.

AMERICAN OIL CHEMIST'S SOCIETY (AOCS). Official method Ce 1-62: fatty acid composition by gas chromatography. In Official Methods and Recommended Practices of the AOCS. Champaign, IL, USA: American Oil Chemists' Society, 1997.

BAKIRCI, I.; KAVAZ, A. An investigation of some properties of banana yogurts made with commercial ABT-2 starter culture during storage. International Journal of Dairy Technology, v. 61, p. $270-276,2008$.

BAZZOCCO, S.; MATTILA, I.; GUYOT, S.; RENARD, C. M. G. C; AURA, A. M. Factors affecting the conversion of apple polyphenols to phenolic acids and fruit matrix to short-chain fatty acids by human faecal microbiota in vitro. European Journal of Nutrition, v. 47, p. 442 - 452, 2008.

BENITEZ-SÁNCHEZ, P.L.; LEÓN-CAMACHO, M.; APARICIO, R.A. Comprehensive study of hazelnut oil composition with comparisons to other vegetable oils, particularly olive oil. European Food Research Technology, v. 218, p. 13-19, 2003.

BEZKOROVAINY, A. Probiotics: determinants of survival and growth in the gut. American Journal of Clinical Nutrition, v. 73, p. 399 - 405, 2001.

BIALONSKA, D.; KASIMSETTY, S.; SCHRADER, K.; FERREIRA, D. (2009). The effect of pomegranate (Punica granatum L.) byproducts and ellagitannins on the growth of human gut bacteria. Journal of Agricultural and Food Chemistry, v. 57(18), p. 8344 - 8349.

BISAKOWSKI, B.; ATWAL, A.; GARDNER, N.; CHAMPAGNE, C. Effect of lactic acid fermentation of onions (Allium cepa) on the composition of flavonol glucosides. International Journal of Food Science and Technology, v. 42 (7), p. 783 - 789, 2007.

BLANCO-GOMIS, D.; ALONSO, J. J. M.; CABRALES, I. M.; ABRODO, P. A. Characterization of cider apples on the basis of their fatty acid profiles. Journal of Agricultural and Food Chemistry, v. 50, p. 1097-1100, 2002.

BOMBA, A.; JONECOVÁ, Z; KOSCOVÁ, J.; NEMCOVÁ, R.; GANCARCKOVÁ, S.; MUDRONOVÁ, D.; SCIRANKOVÁ, L.; BULECA, V.; LAZAR, G.; POSIVAK, J.; KASTEL, R.; MAREKOVÁ, M. The improvement of probiotics efficacy by synergistically acting components of natural origin: a review. Biologia, v. 61, p. 712-729, 2006. 
BOMBA, A.; NEMCOVÁ, R.; MUDRONOVÁ, D.; GUBA, P. The possibilities of potentiating the efficacy of probiotics. Trends in Food Science \& Technology, v. 13, p. 121-126, 2002.

BRANDÃO, S.C.C. Novas Gerações de Produtos Lácteos Funcionais. Rev. Indústria de Laticínios, v.1, p. 64-66, 2002.

BRASIL. Ministério da Agricultura, Pecuária e Abastecimento. O setor produtivo da fruticultura. Disponível em: http://www.agricultura.gov.br/. Última atualização: 06/08/2007. Acesso em: 03 mar. 2008.

BRASIL. Ministério da Agricultura, Pecuária e Abastecimento. Legislação. Sislegis. Instrução Normativa SDA n.22, 14 de abril de 2003. Oficializa os métodos analíticos oficiais físicoquímicos, para controle de leite e produtos lácteos, em conformidade com o anexo desta Instrução Normativa, determinando que sejam utilizados no Sistema de Laboratório Animal do Departamento de Defesa Animal. Disponível em: http://extranet.agricultura.gov.br/sislegisconsulta/consultarLegislacao.do? operacao= visualizar\&id= 399. Acesso em: 6 dez. 2007.

BRASIL. Ministério da Saúde. Agência Nacional de Vigilância Sanitária. Resolução n. 18, de 30 de abril de 1999. Aprova o Regulamento Técnico que Estabelece as Diretrizes Básicas para Análise e Comprovação de Propriedades Funcionais e ou de Saúde Alegadas em Rotulagem de Alimentos. Brasília, 1999a.

BRASIL. Ministério da Saúde. Agência Nacional de Vigilância Sanitária. Resolução n. 19, de 30 de abril de 1999. Aprova o Regulamento Técnico de Procedimentos para Registro de Alimento com Alegação de Propriedades Funcionais e ou de Saúde em sua Rotulagem. Brasília, 1999b.

CELIK, S.; BAKIRCI, I. Some properties of yoghurt produced by adding mulberry pekmez (concentrated juice). International Journal of Dairy Technology, v. 56, p. 26-29, 2003.

CHAMPAGNE, C. P.; GARDNER, N. J. Effect of storage in a fruit drink on subsequent survival of probiotic lactobacilli to gastrointestinal stresses. Food Research International, v. 41, p. 539 - 543 , 2008.

CHARALAMPOPOULOS, D.; PANDIELLA, S. Survival of human derived Lactobacillus plantarum in fermented cereal extracts during refrigerated storage. LWT-Food Science and Technology, v. 43 (3), p. $431-435,2010$.

CHAU, C. F.; HUANG, Y. L. Effects of the insoluble fiber derived from Passiflora edulis seed on plasma and hepatic lipids and fecal output. Molecular Nutrition and Food Research, v. 49, p. 786 790, 2005. 
CHEN, H.; RUBENTHALER, G. L.; LEUNG, H. K.; BARANOWSKI, J. D. Chemical, physical, and baking properties of apple fiber compared with wheat and oat bran cereal. Cereal Chemistry, v. 65, p. 244-247, 1988.

COLLADO, M. C.; ISOLAURI, E.; SALMINEN, S.; SANZ, Y. The impact of probiotic on gut health. Current Drug Metabolism, v. 10, p. 68 - 78, 2009.

CORDOVA, K. R. V.; GAMA, T. M. M. T. B.; WINTER, C. M. G.; KASKANTZIS NETO, G.; FREITAS, R. J. S. Physico-chemical characteristics of yellow passion fruit (Passiflora edulis flavicarpa Degener) peel after a drying process. Boletim do CEPPA, v. 23, p. 221-230, 2005.

CORREA, S.; CASTRO, I.; SAAD, S. Probiotic potential and sensory properties of coconut flan supplemented with Lactobacillus paracasei and Bifidobacterium lactis. International Journal of Food Science and Technology, v. 43(9), p. 1560 - 1568, 2008.

COSKUN, H.; ONDUL, E. Free fatty acid accumulation by mesophilic lactic acid bacteria in cold stored milk. Journal of Microbiology, v. 42, p. 133-138, 2004.

COSTABILE, A.; KLINDER, A.; FAVA, F.; NAPOLITANOA, A.; FOGLIANOA, V.; LEONARDA, C. Plain-grain wheat breakfast cereal has a prebiotic effect on the human gut microbiota: a double-blind, placebo-controlled, crossover study. British Journal of Nutrition, v. 99, p. $110-120,2008$.

DAMIN, E.R.; MINOWA, E.; ALCÂNTA, M.R.; OLIVEIRA, M.N. Effect of cold storage on culture viability and some rheological properties of fermented milk prepared with yogurt and probiotic bacteria. Journal of Texture Studies, v. 39, p. 40-55, 2008.

DAS, U.N.; FAMS, M.D. Essential fatty acid as possible enhancers of the beneficial actions of probiotics. Nutrition, v. 18, p. 786-789, 2002.

DAVE, R. I.; SHAH, N. P. Evaluation of media for selective enumeration of Streptococcus thermophillus, Lactobacillus delbrueckii subsp. bulgaricus, Lactobacillus acidophilus and bifidobacteria. Journal of Dairy Science, v. 79, p. 1529 - 1536, 1996.

DAVIS, C. D.; MILNER, J. A. Gastrointestinal microflora, food components and colon cancer prevention. Journal of Nutritional Biochemistry, v. 20, p. 743-752, 2009.

DEMAN, J.M. Consistency of fats: a review. Journal of the American Oil Chemists' Society, v. 60, p. 6-11, 1983.

DESAI, A. R., POWELL, I. B., SHAH, N. P. Survival and activity of probiotic lactobacilli in skim milk containing prebiotics. Journal of Food Science, v. 69, p. 57-60, 2004. 
DIBAISE, J., ZHANG, H., CROWELL, M., KRAJMALNIK-BROWN, R., DECKER, G., RITTMANN, B. Gut microbiota and its possible relationship with obesity. Mayo Clinic Proceedings, v. 83 (4), p. $460-469,2008$.

DONKOR, O. N.; HENRIKKSON, A.; VASILJEVIC, T.; SHAH, N. P. Effect of acidification on the activity of probiotics in yoghurt during cold storage. International Dairy Journal, v. 16, p. 1181-1189, 2006.

DONKOR, O. N.; TSANGALIS, D.; SHAH, N. P. Viability of probiotic bacteria and concentrations of organic acids in commercial yoghurts during refrigerated storage. Food Australia, v. 59 (4), p. $121-126,2007$.

DONKOR, O.N.; HENRIKKSON, A.; VASILJEVIC, T.; SHAH, N.P. Effect of acidification on the activity of probiotics in yoghurt during cold storage. International Dairy Journal, v. 16, p. 11811189,2006

DONKOR, O.N.; NILMINI, S.L.I.; STOLIC, P.; VASILJEVIC, T.; SHAH, N.P. Survival and activity of selected probiotic organisms in set-type yoghurt during cold storage. International Dairy Journal, v. 17, p. 657-665, 2007.

ECKBURG, P. B.; BIK, E. M.; BERNSTEIN, C. N.; PURDOM, E.; DETHLEFSEN, L.; SARGENT, M. Diversity of the human intestinal microbial flora. Science, v. 308, p. 1635 - 1638, 2005.

EDWARDS, C. A.; PARRETT, A. M. Intestinal flora during the first months of life: new perspectives. British Journal of Nutrition, v. 88, Suppl. 1, p.11-18, 2002.

EKINCI, F. Y.; OKUR, O. D.; ERTEKIN, B.; GUZEL-SEYDIM, Z. Effects of probiotic bacteria and oils on fatty acid profiles of cultured cream. European Journal of Lipid Science and Technology, v. 110, p. 216-224, 2008.

EMAGA, T. H.; ANDRIANAIVO, R. H.; WATHELET, B.; TCHANGO, J. T.; PAQUOT, M. Effects of the stage of maturation and varieties on the chemical composition of banana and plantain peels. Food Chemistry, v. 103, p. 590- 600, 2007.

EMAGA, T. H.; ROBERT, C.; RONKART, S. N.; WATHELET, B.; PAQUOT, M. Dietary fibre components and pectin chemical features of peels during ripening in banana and plantain varieties. Bioresource Technology, v. 99, p. 4346-4354, 2008. 
EMPRAPA. Empresa Brasileira de Agricultura e Pecuaria. Centro Nacional de Pesquisa de Mandioca e Fruticultura. Retrieved in November, 2010, from http://www.cnpmf.embrapa.br/index.php?p=pesquisaculturas_pesquisadasmaracuja.php\&menu

ESPIRITO SANTO, A. P.; PEREGO, P.; CONVERTI, A.; OLIVEIRA, M. N. Influence of food matrices on probiotic viability - a review focusing on the fruity bases. Trends in Food Science \& Technology, v. 22, p. 377-385, 2011.

ESPÍRITO SANTO, A. P.; SILVA, R. C.; SOARES, F. A .S. M.; ANJOS, D.; GIOIELLI, L. A.; OLIVEIRA, M. N. Açai pulp addition improves fatty acid profile and probiotic viability in yoghurt. International Dairy Journal, v. 20, p. 415-422, 2010.

FAO/WHO. Guidelines for the evaluation of probiotics in food: Report of a joint FAO/WHO working group on drafting guidelines for the evaluation of probiotics in food. London: FAO/WHO. Available in: ftp://ftp.fao.org/es/esn/food/wgreport2.pdf. 2002.

FAO/WHO. Health and nutritional properties of probiotics in food including powder milk with live lactic acid bacteria. Cordoba, Argentina: Food and Agriculture Organization of the United Nations and World Health Organization Expert Consultation Report. Retrieved September 2, 2008, from http://www.who.int/foodsafety/publications/fs_management/probiotics/en/index.html, 2001.

FAO/WHO. Agricultural biodiversity in FAO. Rome, Italy. Retrieved April 6, 2009, from ftp://ftp.fao.org/docrep/fao/010/i0112e/i0112e.pdf, 2008.

FARIA, C.P.; BENEDET, H.D.; LE GUERROUE, J.L. Parâmetros de produção de leite de búfala fermentado por Lactobacillus casei. Pesq. agropec. bras., v.41, n.3, p.511-516, 2006.

FARNWORTH, E. R. The evidence to support health claims for probiotics. Journal of Nutrition, v. 138, p. 1250-1254, 2008.

FAVARO-TRINDADE, C.; BERNARDI, S.; BODINI, R.; BALIEIRO, J. C. C.; DE ALMEIDA, E. Sensory acceptability and stability of probiotic microorganisms and Vitamin $\mathrm{C}$ in fermented acerola (Malpighia emarginata DC.) ice cream. Journal of Food Science, v. 71 (6), p. 492 - 495, 2006.

FERNANDEZ-GARCIA, E., MCGREGOR, J. U. Fortification of sweetened plain yogurt with insoluble dietary fiber. Zeitschrift für Lebensmitteluntersuchung und-Forschung A, v. 204, p. 433437, 1997.

FLORENCE, A. C.; SILVA, R. C.; ESPÍRITO SANTO, A. P.; GIOIELLI, L. A.; TAMIME, A. Y.; OLIVEIRA, M. N. Increased CLA content in organic milk fermented by bifidobacteria or yoghurt cultures. Dairy Science and Technology, v. 89, p. 541-553, 2009. 
FOLKENBERG, D. M.; DEJMEK, P.; SKRIVER, A.; GULDAGER, H. S.; IPSEN, R. Sensory and rheological screening of exopolysaccharide producing strains of bacterial yogurt cultures. International Dairy Journal, v. 16, p. 111-118, 2006.

FOO, H. L.; LOH, T. C.; LIM, Y. S.; SHUKRIYAH, M. H.; KUFLI, C. N.; LAW, F. L. Effects of fermented fruits on growth performance, shedding of Enterobacteriaceae and lactic acid bacteria and plasma cholesterol in rats. Pakistan Journal of Nutrition, v. 2(4), p. 228 - 233, 2008.

FOOD PROCESSING. 2009. Modest growth for global probiotic market, 2009. Disponível em http://www.foodprocessing.com/articles/2008/383.html. Acesso em 20 de Julho de 2011.

FRANK, D. N.; PACE, N. R. Gastrointestinal microbiology enters the metagenomics era. Current Opinion in Gastroenterology, v. 24, p. 4 -10, 2008.

FURTADO, M.; FARIA, S.; FARIA, O. Probiotics, prebiotics, gut microbiota and obesity: can manipulation of the gut microbiota accentuate gastric bypass success? a review. Obesity Surgery, v. 24(1), p. $1021-1022,2010$.

GAREAU, M.; SHERMAN, P.; WALKER, W. Probiotics and the gut microbiota in intestinal health and disease. Nature Reviews Gastroenterology \& Hepatology, v. 7, p. 503 - 514, 2010.

GODWARD, G.; SULTANA, K.; KAILASAPATHY, K.; PEIRIS, P.; ARUMUGASWAMY, R.; REYNOLDS, N. The importance of strain selection on the viability and survival of probiotic bacteria in dairy foods. Milchwissenschaft, v. 55, p. $441-445,2000$.

GOMES, A.M.P.; MALCATA, F.X. Use of small ruminants' milks supplemented with available nitrogen as growth media for Bifidobacterium lactis and Lactobacillus acidophilus. Journal of Applied Microbiology, v. 85, p. 839-848, 1998.

GRANATO, D.; BRANCO, G. F.; CRUZ, G.; FARIA, J. F.; SHAH, N. P. Probiotic dairy products as functional foods. Comprehensive Reviews in Food Science and Food Safety, v. 9, p. 455 - 470, 2010.

GRANATO, D.; BRANCO, G. F.; NAZZARO, F.; CRUZ, A. G.; FARIA, J. A. F. Functional foods and nondairy probiotic food development: trends, concepts, and products. Comprehensive Reviews in Food Science and Food Safety, v. 9, p. 292-302, 2010.

GUARNER, F.; MALAGELADA, J. R. Gut flora in health and disease. Lancet, v. 361, p. 512 $519,2003$. 
GUERGOLETTO, K. B.; MAGNANI, M.; SAN MARTIN, J.; ANDRADE, C. G. T. J.; GARCIA, S. Survival of Lactobacillus casei (LC-1) adhered to prebiotic vegetal fibers. Innovative Food Science and Emerging Technologies, v. 11, p. 415 - 421, 2010.

GUERZONI, M. E.; LANCIOTTI, R.; COCCONCELLI, P. S. Alteration in cellular fatty acid composition as a response to salt, acid, oxidative and thermal stresses in Lactobacillus helveticus. Microbiology, v. 147, p. 2255-2264, 2001.

GUVEN, M.; YASAR, K.; KARACA, O.B.; HAYALOGLU, A.A. The effect of inulin as a fat replacer on the quality of set-type low-fat yogurt manufacture. International Journal of Dairy Technology, v. 58, p. 180-184, 2005.

HAYES, M.; COAKLEY, M.; O’SULLIVAN, L.; STANTON, C.; HILL, C.; FITZGERALD, G. F. Cheese as a delivery vehicle for probiotics and biogenic substances. Australian Journal of Dairy Technology, v. 61, p. $132-141,2006$.

HERTOG, M.G.L; FESKENS, E.J.M; KROMHOT, D; HOLLMAN, P.C.H; KATAN, N.M.B. The Lancet, v. 342, p. 1007-1011, 1993.

HOMMA, A.K.O. Biopirataria na Amazônia: como reduzir os riscos? Amazônia: Ciênc. \& Desenv., v.1 (1), p. 47-60, 2005.

ISO. Milk and milk products - extraction methods for lipids and liposoluble compounds. ISO Standard 14156, Geneva, Switzerland: International Organization for Standardization, 2001.

ISO. Milk fat - preparation of fatty acid methyl esters. ISO Standard 15884, Geneva, Switzerland: International Organization for Standardization, 2002.

ISOLAURI, E. Probiotics in preterm infants: a controversial issue. Journal of Pediatric Gastroenterology and Nutrition, v. 45, p. 188 - 189, 2007.

ISOLAURI, E.; KALLIOMAKI, M.; RAUTAVA, S.; SALMINEN, S.; LAITINEN, K. Obesity extending the hygiene hypothesis. Microbial- Host Interaction: Tolerance Versus Allergy, v. 64, p. $75-89,2009$.

ISOLAURI, E.; SALMINEN, S.; OUWEHAND, A. C. Manipulation of the gut microbiota: probiotics. Bailliere’s Best Practice Clinical Gastroenterology, v. 18, p. 299 - 313, 2004.

JANEBRO, D. I.; QUEIROZ, M. S. R.; RAMOS, A.; SABAA-SRUR, A. U. O.; CUNHA, M. A. L.; DINIZ, M. F. Effect of the flour of the yellow passion fruit peel (Passiflora edulis f. flavicarpa Deg.) in the glycemic and lipid levels of type 2 diabetes patients. Brazilian Journal of Pharmacognosy, v. 18, p. 724-732, 2008. 
JORDANO, R.; SERRANO, E. C.; TORRES, M.; SALMERON, J. Comparison of three M17 media for the enumeration of Streptococcus thermophilus in fermented dairy products. Journal of Food Protection, v. 55, p. 999-1000, 1992.

KAILASAPATHY, K.; HARMSTORF, I.; PHILLIPS, M. Survival of Lactobacillus acidophilus and Bifidobacterium animalis ssp lactis in stirred fruit yogurts. LWT-Food Science and Technology, v. 41(7), p. $1317-1322,2008$.

KANKAANPÄA, P. E.; SALMINEN, S. J.; ISOLAURI, E.; LEE, Y. K. The influence of polyunsaturated fatty acid on probiotic growth and adhesion. FEMS Microbiology Letters, v. 194, p. 149-153, 2001.

KANKAANPÄA, P. E.; YANG, B.; KALLIO, H.; ISOLAURI, E.; SALMINEN, S. Effects of polyunsaturated fatty acid in growth medium on lipid composition and on physicochemical surface properties of Lactobacilli. Applied and Environmental Microbiology, v. 70, p. 129-136, 2004.

KAUR, N.; GUPTA, A. K. Applications of inulin and oligofructose in health and nutrition. Journal of Bioscience, v. 27, p. 703-714, 2002.

KELI, S. O; HERLOG, M. G. L; FESKENS, E. J. M.; KROMHOUT, D. Dietary flavonoids, antioidant vitamins, and incidence of stroke; the Zutphen study. Arch. Internal Medicine, v. 156, p. 637-641, 1996.

KELLY, D.; CONWAY, S.; AMINOV, R. Commensal gut bacteria: mechanisms of immune modulation. Trends in Immunology, v. 26, p. 326 - 333, 2005.

KHURANA, H. K.; KANAWJIA, S. K. Recent trends in development of fermented milks. Current Nutrition \& Food Science, v. 3, p. 91-108, 2007.

KIM, D. C.; CHAE, H. J.; IN, M. J. Fermentation characteristics of Korean pear (Pyrus pyrifolia Nakai) puree by the Leuconostoc mesenteroides 51-3 strain isolated from kimchi. African Journal of Biotechnology, v. 9, p. 5735 - 5738, 2010.

KIM, Y. J.; LIU, R. H. Increase of conjugated linoleic acid content in milk by fermentation with lactic acid bacteria. Journal of Food Science, v. 67, p. 1731-1737, 2002.

KLEWICKA, E.; ZDUNCZYK, Z.; JUSKIEWICZ, J. Effect of lactobacillus fermented beetroot juice on composition and activity of cecal microflora of rats. European Food Research and Technology, v. 229 (1), p. 153 - 157, 2009.

KNEKT P; JÄRVINEN R; REUNANEN A; MAATELA. J. Flavonoid intake and coronary mortality in Finland: a corhort study. Brit. Med. J. , v. 312, p. 478-481, 1996. 
KODAKA, H.; MIZUOCHI, S.; TERAMURA, H.; NIRAZUKA, T. Comparison of the compact dry TC method with the standard pour plate method (AOAC Official Method 966.23) for determining aerobic colony counts in food samples. Journal of AOAC International, v. 88, p. 1702$1713,2005$.

KOURKOUTAS, Y.; BOSNEA, L.; TABOUKOS, S.; BARAS, C.; LAMBROU, D.; KANELLAKI, M. Probiotic cheese production using Lactobacillus casei cells immobilized on fruit pieces. Journal of Dairy Science, v. 89, p. 1439-1451, 2006.

KOURKOUTAS, Y.; KANELLAKI, M.; KOUTINAS, A. Apple pieces as immobilization support of various microorganisms. LWT-Food Science and Technology, v. 39, n. 9, p. 980 - 986, 2006.

KUMAR, P.; MISHRA, H. N. Effect of mango pulp and soy milk fortification on the texture profile of set yoghurt made from buffalo milk. Journal of Texture Studies, v. 34, p. 249-269, 2003.

KUN, S.; REZESSY-SZABO, J.; NGUYEN, Q.; HOSCHKE, A. Changes of microbial population and some components in carrot juice during fermentation with selected Bifidobacterium strains. Process Biochemistry, v. 43, n. 8, p. 816-821, 2008.

KUSKOSKI, E.M; ASUERO, A.G; TRONCOSO, A.M; MANCINI-FILHO, J; FETT, R. Determination de la capacidad antioxidante de pulpa de frutos. Ciênc. Tecnol. Aliment., v. 25, n. 4, p. 726-732, 2005.

LAMSAL, B. P.; FAUBION, J. M. The beneficial use of cereal and cereal components in probiotic foods. Food Reviews International, v. 25, p. 103-114, 2009.

LANKAPUTHRA, W. E. V.; SHAH, N. P. A simple method for selective enumeration of Lactobacillus acidophilus in yoghurt supplemented with L. acidophilus and Bifidobacterium spp. Milchwissenschaft, v. 51, p. 446 - 451, 1996.

LICHTENTHÄLER， R.; BELANDRINO， R.; RODRIGUES， J. G. $\quad$ S. $\quad$ M.; PAPAGIANNOPOULOS, M.; FABRICIUS, H.; MARX, F. Total oxidant scavenging capacities of Euterpe oleracea Mart. (Açai) fruits. International Journal of Food Sciences and Nutrition, v. 56, p. 53-64, 2005.

LIN, W. H.; HWANG, C. F.; CHEN, L. W.; TSEN, H. Y. Viable counts, characteristic evaluation for commercial lactic acid bacteria products. Food Microbiology, v. 23, p. 74-81, 2006.

LIU, S.; YANG, F.; LI, J.; ZHANG, C. ; HONG, P. Physical and chemical analysis of Passiflora seeds and seed oil from China. International Journal of Food Sciences and Nutrition, v. 59, p. 706$715,2008$. 
LOURENS-HATTINGH, A.; VILJOEN, B. C. Growth and survival of a probiotic yeast in dairy products. Food Research International, v. 34, p. 791 - 796, 2001.

LOUSADA JR, J. E.; COSTA, J. M. C.; NEIVA, J. N. M.; RODRIGUEZ, N. M. Physical-chemical characterization of tropical fruit by-products for use in animal feed. Revista Ciência Agronômica, v. 37, p. 70-76, 2006.

LUCKOW, T.; DELAHUNTY, C. Which juice is healthier? A consumer study of prebiotic nondairy juice drinks. Food Quality and Preference, v. 15, p. 751 - 759, 2004.

MACFARLANE, S., MACFARLANE, G. T. Bacterial diversity in the human gut. Advances in Applied Microbiology, v. 54, p. 261 - 289, 2004.

MACFARLANE, S.; MACFARLANE, G. T. Regulation of short-chain fatty acid production. Proceedings of the Nutrition Society, v. 62, p. 67-72, 2003.

MARAFON, A. P; SUMI, A.; ALCÂNTARA, M. R.; TAMIME, A. Y.; OLIVEIRA, M. N. Optimization of the rheological properties of probiotic yoghurts supplemented with milk proteins. LWT - Food Science and Technology, v. 44, p. 511-519, 2011.

MARAGKOUDAKIS, P. A.; MIARIS, C.; ROJEZ, P.; MANALIS, N.; MAGKANARI, F.; KALANTZOPOULOS, G.; TSAKALIDOU, E. Production of traditional Greek yoghurt using Lactobacillus strains with probiotic potential as starter adjuncts. International Dairy Journal, v. 16, p. 52-60, 2006.

MENEZES, E. M. S.; TORRES, A. T.; SRUR, A. U. S. Valor nutricional da polpa de açai (Euterpe oleracea Mart) liofilizada. Acta Amazônica, v. 38, p. 311 - 316, 2008.

MERENSTEIN, D.; MURPHY, M.; FOKAR, A.; HERNANDEZ, R. K.; PARK, H.; NSOULI, H. Use of a fermented dairy probiotic drink containing Lactobacillus casei (DN-114 001) to decrease the rate of illness in kids: the DRINK study a patient-oriented, doubleblind, cluster-randomized, placebo-controlled, clinical trial. European Journal of Clinical Nutrition, v. 64, p. 669 - 677, 2010.

MERTENS-TALCOTT, S.U.; RIOS, J.; JILMA-STOHLAWETZ, P. J.; PACHECO-PALENCIA, L.A.; MEIBOHM, B.; TALCOTT, S. T.; DERENDORF, H. Pharmacokinetics of anthocyanins and antioxidant effects after the consumption of anthocyanin-rich açai juice and pulp (Euterpe oleracea Mart.) in human healthy volunteers. Journal of Agriculture and Food Chemistry, v. 56, p. 7796$7802,2008$. 
MICHIDA, H.; TAMALAMPUDI, S.; PANDIELLE, S. S.; WEBB, C.; FUKUDA, H.; KONDO, A.; Efect of cereal extracts and cereal fiber on viability of Lactobacillus plantarum under gastrointestinal tract conditions. Biochemical Engineering Journal, v. 28, p. 73-78, 2006.

MOHAPATRA, D.; MISHRA, S.; SUTAR, N. Banana and its by-product utilization: an overview. Journal of Scientific and Industrial Research, v. 69, p. 323-329, 2010.

MOUSAVI, Z. E.; MOUSAVI, S. M.; RAZAVI, S. H.; EMAM-DJOMEH, Z.; KIANI, H. Fermentation of pomegranate juice by probiotic lactic acid bacteria. World Journal of Microbiology and Biotechnology, v. 27(1), p. 123 - 128, 2010.

MUÑIZ-MIRET, N.; VAMOS, R.; HIRAOKA, M.; MONTAGNINI, F.; MENDELSOHN, R. The economic value of managing the Açay palm (Euterpe oleracea Mart.) in flood plains of the Amazon estuary, Pará, Brazil. Forest Ecology and Management, v. 87, p. 163-173, 1996.

NARAIN, N.; ALMEIDA, J. N.; GALVÃO, M. S.; MADRUGA, M. S.; BRITO, E. S. Volatile compounds in passion fruit (Passiflora edulis f. flavicarpa) and yellow mombin (Spondias mombin L) fruits obtained by dynamic headspace technique. Ciência e Tecnologia de Alimentos, v. 24, p. $212-216,2004$.

NASCIMENTO, R. J. S.; COURI, S.; ANTONIASSI, R.; PEREIRA, S. F. Composição em ácidos graxos do óleo da polpa de açai extraído com enzimas e com hexano. Revista Brasileira de Fruticultura, v. 30, p. 498-502, 2008.

NAWIRSKA, A.; KWASNIEWSKA, M. Dietary fibre fractions from fruit and vegetable processing waste. Food Chemistry, v. 91, p. 221-225, 2005.

NAZZARO, F., FRATIANNI, F., SADA, A., ORLANDO, P. Synbiotic potential of carrot juice supplemented with Lactobacillus spp. and inulin or fructooligosaccharides. Journal of the Science of Food and Agriculture, v. 88, p. 2271 - 2276, 2008.

NICOLESCU, C. L., BURULEANU, L. C. Correlation of some substrate parameters in growing Lactobacillus acidophilus on vegetable and fruit cocktail juices. Bulletin of the University of Agricultural Sciences and Veterinary Medicine, v. 67(2), p. 352 - 359, 2010.

NIELSEN, J. W., GILLILAND, S. E. The lactose hydrolyzing enzyme from Lactobacillus acidophilus. Cultured Dairy Products Journal, v. 27, p. 20-28, 1992.

NYANZI, S. A., CARSTENSEN, B., SCHWACK, W. A. Comparative study of fatty acid profiles of Passiflora seed oils from Uganda. Journal of the American Oil Chemists' Society, v. 82, p. 4144, 2005. 
OGAWA, J., KISHINO, S., ANDO, A., SUGIMOTO, S., MIHARA, K., SHIMIZU, S. Production of conjugated fatty acid by lactic acid bacteria. Journal of Bioscience and Bioengineering, v. 100, p. 355-364, 2005.

OH, D. K., HONG, G. H., LEE, Y., MIN, S., SIN, H. S., CHO, S. K. Production of conjugated linoleic acid by isolated Bifidobacterium strains. World Journal of Microbiology and Biotechnology, v. 19, p. 907-912, 2003.

OLIVEIRA, L. F.; NASCIMENTO, M. R. F.; BORGES, S. V.; RIBEIRO, P. C. N.; RUBACK, V. R. Aproveitamento alternativo da casca do maracujá-amarelo (Passiflora edulis F., Passifloraceae) para produção de doce em calda. Ciênc. Tecnol. Aliment., v. 22, n. 3, p. 259-262, 2002.

OLIVEIRA, M. N.; SODINI, I.; REMEUF, F.; CORRIEU, G. Effect of milk supplementation and culture composition on acidification, textural properties and microbiological stability of fermented milks containing probiotic bacteria. International Dairy Journal, v. 11, p. 935-942, 2001.

OLIVEIRA, M. N.; DAMIN, M. R. Efeito do teor de sólidos e da concentração de sacarose na acidificação, firmeza e viabilidade de bactérias do iogurte e probióticas em leite fermentado. Ciênc. Tecnol. Aliment., Campinas, 23(Supl), p. 172 - 176, 2003.

OliveirA, R. P. S.; FlORENCE, A. C. R.; SIlvA, R. C.; PEREGO, P.; CONVERTI, A.; GIOIELLI, L. A.; OLIVEIRA, M. N. Effect of different prebiotics on the fermentation kinetics, probiotic survival and fatty acid profiles in nonfat symbiotic fermented milk. International Journal of Food Microbiology, v. 128, p. 467-472, 2009.

ORHAN, I.; KUSMENOGLU, S.; SENER, B. Fatty acid profile of fresh and dried banana (Musa sapientum var. cavandish, Lamb.). Journal of Faculty of Pharmacy, Ankara, Turkey, v. 31, p. 13$19,2002$.

OSMAN, N.; ADAWI, D.; AHRNE, S.; JEPPSSON, B.; MOLIN, G. Probiotics and blueberry attenuate the severity of dextran sulfate sodium (DSS)- induced colitis. Digestive Diseases and Science, v. 53, p. $2464-2473,2008$.

ÖZER, D.; AKIN, S.; ÖZER, B. Effect of inulin and lactulose on survival of Lactobacillus acidophilus LA-5 and Bifidobacterium bifidum BB-02 in acidophilus-bifidus yoghurt. Food Science and Technology International, v. 11, p. 19-24, 2005.

OZTURK, B.A., ONER, M.D. Production and evaluation of yogurt with concentrated grape juice. Journal of Food Science, v. 64, p. 530-532, 1999. 
PARKAR, S., STEVENSON, D., SKINNER, M. The potential influence of fruit polyphenols on colonic microflora and human gut health. International Journal of Food Microbiology, v. 124 (3), p. $295-298,2008$.

PERDigON, G., GALDEANO, C. M.; VALDEZ, J. C., MEDICI, MInteraction of lactic acid bacteria with the gut immune system. European Journal of Clinical Nutrition, v. 56, p. 21 - 26, 2002.

POSSEMIERS, S.; MARZORATI, M.; VERSTRAETE, W.; VAN DE WIELE, T. Bacteria and chocolate: a successful combination for probiotic delivery. International Journal of Food Microbiology, v.141, p. 97 - 103, 2010.

PRANDINI, A.; SIGOLO, S.; TANSINI, G.; BROGNA, N.; PIVA, G. Different level of conjugated linoleic acid (CLA) in dairy products from Italy. Journal of Food Composition and Analysis, v. 20, p. 472-479, 2007.

PUUPPONEN-PIAMIEA, R., AURA, A. M., OKSMAN-CALDENTEY, K. M., MYLLARINEN, P., SAARELA, M., MATTILA-SANDHOLM, T. Development of functional ingredients for health gut. Trends in Food Science \& Technology, v. 13, p. 3 - 11, 2003.

RAMCHANDRAN, L, SHAH, N. P. Effect of exopolysaccharides on the proteolytic and angiotensin-I converting enzyme-inhibitory activities and textural and rheological properties of lowfat yogurt during refrigerated storage. Journal of Dairy Science, v. 92, p. 895-906, 2009.

RAVULA, R. R.; SHAH, N. P. Selective enumeration of Lactobacillus casei from yogurt and fermented milk drinks. Biotechnology Techniques, v. 12, p. 819 - 822, 1998.

RAWSON, H. L. MARSHALL, V. M. Effect of 'ropy' strains of Lactobacillus delbrueckii ssp.bulgaricus and Streptococcus thermophilus on rheology of stirred yoghurt. International Journal of Food Science and Technology, v. 32, p. 213-220, 1997.

REID, G.; SANDERS, M.E.; GASKINS, R.; GIBSON, G.R.; MERCENIER, A.; RASTALL, R.; ROBERFROID, M.; ROWLAND, I.; CHERBUT, C.; KLAENHAMMER, T. New scientific paradigms for proiotics and prebiotics. J. Clinical GastroenteroLogy, v.37, n.2, p.105-118, 2003.

RENARD, C. M. G. C.; CRÉPEAU, M. J.; THIBAULT, J. F. Structure of the repeating units in the rhamnogalacturonic backbone of apple, beet and citrus pectins. Carbohydrate Research, v. 275, p. 155-165, 1995. 
RIPA, F. A.; HAQUE, M.; NAHAR, L.; ISLAM, M. Antibacterial, cytotoxic and antioxidant activity of Passiflora edulis Sims. European Journal of Scientific Research, v. 31, p. 592-598, 2009.

ROBERFROID, M.; GIBSON, G.; HOYLES, L. Prebiotic effects: metabolic and health benefits. British Journal of Nutrition, v. 104, p. 1 - 63, 2010.

ROCHA, A. P. M.; CARVALHO, L. C. R. M.; SOUSA, M. A. V.; MADEIRA, S. V. F.; SOUSA, P. J. C.; TANO, T.; SCHINI-KERTH, V. B.; RESENDE, A. C.; MOURA, R. S. Endotheliumdependent vasodilator effect of Euterpe oleracea Mart. (Açaí) extracts in mesenteric vascular bed of the rat. Vascular PharmacoLogy, v. 46 (2), p. 97-104, 2007.

ROßLE, C.; AUTY, M. A. E.; BRUNTONA, N.; GORMLEY, R. T.; BUTLER, F. Evaluation of fresh-cut apple slices enriched with probiotic bacteria. Innovative Food Science and Emerging Technologies, v. 11, p. $203-209,2010$.

SAARELA, M.; VIRKAJARVI, I.; ALAKOMI, H. L.; SIGVART-MATTILA, P.; MATTO, J. Stability and functionality of freeze-dried probiotic Bifidobacterium cells during storage in juice and milk. International Dairy Journal, v. 16, p. 1477 - 1482, 2006.

SACCARO, D. M.; TAMIME, A. Y.; PILLEGGI, A. L. O. P. S.; OLIVEIRA, M. N. The viability of three probiotic organisms grown with yoghurt starter cultures during storage for 21 days at $4^{\circ} \mathrm{C}$. International Journal of Dairy Technology, v. 62, p. 397- 404, 2009.

SALGADO, J. M.; BOMBARDE, T. A. D.; MANSI, D. N.; PIEDADE, S. M. S.; MELETTI, L. M. M. Effects of different concentrations of passion fruit peel (Passiflora edulis) on the glicemic control in diabetic mice. Ciência e Tecnologia de Alimentos, v. 30, p. 784-789, 2010.

SALONEN, A.; DE VOS, W.; PALVA, A. Gastrointestinal microbiota in irritable bowel syndrome: present state and perspectives. Microbiology, v. 156, p. 3205 - 3215, 2010.

SANABRIA, N.; SANGRONIS, E. Caracterización del acai o manaca (Euterpe oleracea Mart.): un fruto del Amazonas. Archivos Latinoamericanos de Nutrición, v. 57, p. 94-99, 2007.

SAXELIN, M.; LASSIG, A.; KARJALAINEN, H.; TYNKKYNEN, S.; SURAKKA, A.; VAPAATALO, H. Persistence of probiotic strains in the gastrointestinal tract when administered as capsules, yoghurt, or cheese. International Journal of Food Microbiology, v. 144, p. 293 - 300 , 2010. 
SAXELIN, M.; GRENOV, B.; SVENSSON, U.; FONDÉN, R.; RENIERO, R.; MATTILASANDHOLM, T. The technoLogy of probiotics. Trends Food Sci. Technol., v. 10, p.387-392, 1999.

SCARPELLINI, E.; CAMPANALE, M.; LEONE, D.; PURCHIARONI, F.; VITALE, G.; LAURITANO, E. C. Gut microbiota and obesity. Internal and Emergency Medicine, v. 5, p. 53 $56,2010$.

SCHAUSS, A. G.; WU, X.; PRIOR, R. L.; OU, B.; PATEL, D.; HUANG, D.; KABABICK, J. P. Phytochemical and nutrient composition of the freeze-dried Amazonian palm berry, Euterpe oleraceae Mart. (Acai). Journal of Agriculture and Food Chemistry, v. 54, p. 8598-8603, 2006.

SCHIEBER, A., STINTZING, F. C., CARLE, R. By-products of plant food processing as a source of functional compounds - recent developments. Trends in Food Science \& Technology, v.12, p. 401-413, 2001.

SEMBRIES, S.; DONGOWSKI, G.; JACOBASCH, G.; MEHRLANDER, K.; WILL, F.; DIETRICH, H. Effects of dietary fibre-rich juice colloids from apple pomace extraction juices on intestinal fermentation products and microbiota in rats. British Journal of Nutrition, v. 90, p. 607 $615,2003$.

SENDRA, E.; FAYOS, P.; LARIO, Y.; FERNANDEZ-LOPEZ, J.; SAYAS-BARBERA, E.; \& PEREZ-ALVAREZ, J. A. Incorporation of citrus fibers in fermented milk containing probiotic bacteria. Food Microbiology, v. 25, p. 13-21, 2008.

SHAH, N.P. Probiotic Bacteria: Selective Enumeration and Survival in Dairy Foods. Journal of Dairy Science, v. 83, p. 894-907, 2000.

SHAH, N. P.; LANKAPUTHRA, W. E. V.; BRITZ, M.; KYLE, W. S. A. Survival of $L$. acidophilus and Bifidobacterium bifidum in commercial yoghurt during refrigerated storage. International Dairy Journal, v. 5, p. 515-521, 1995.

SHEEHAN, V. M.; ROSS, P.; FITZGERALD, G. F. Assessing the acid tolerance and the technological robustness of probiotic cultures for fortification in fruit juices. Innovative Food Science and Emerging Technologies, v. 8, p. 279 - 284, 2007.

SHENE, C.; BRAVO, S. Whey fermentation by Lactobacillus delbrueckii subsp. bulgaricus for exopolysaccharide production in continuous culture. Enzyme and Microbial Technology, v. 40, p. 1578-1584, 2007. 
SIEBER, R.; COLLOMB, M.; AESCHLIMANN, A.; JELEN, P.; EYER, H. Impact of microbial cultures on conjugated linoleic acid in dairy products - a review. International Dairy Journal, v. 14, p. 1-15, 2004.

SILVA, I. M.; SANTANA, A. C.; REIS, M. S. Análise dos retornos sociais oriundos de adoção tecnológica na cultura do açai no estado do Pará. Amazônia: Ciência e Desenvolvimento, v. 2, p. 25-37, 2006.

SIMREN, M.; OHMAN, L.; OLSSON, J.; SVENSSON, U.; OHLSON, K., POSSERUD, I. Clinical trial: the effects of a fermented milk containing three probiotic bacteria in patients with irritable bowel syndrome e a randomized, double-blind, controlled study. Alimentary Pharmacology \& Therapeutics, v. 31, p. $218-227,2010$.

SIRO, I.; KAPOLNA, E.; KAPOLNA, B.; LUGASI, A. Functional food. Product development, marketing and consumer acceptance a review. Appetite, v. 51, p. 456 - 467, 2008.

SODINI, I.; REMEUF, F.; HADDAD, S.; CORRIEU, G. The relative effect of milk base, starter, and process on yogurt texture: a review. Critical Reviews in Food Science and Nutrition, v. 44, p. 113-137, 2004.

SONG, J.; BANGERTH, F. Fatty acids as precursors for aroma volatile biosynthesis in preclimacteric and climacteric apple fruit. Postharvest Biology and Technology, v. 30, p. 113-121, 2003.

SPINNLER, H. E.; CORRIEU, G. Automatic method to quantify starter activity based on pH measurement. Journal of Dairy Research, v. 56, p. 755-764, 1989.

STAFFOLO, M. D.; BERTOLA, N.; MARTINO, M.; BEVILACQUA, A. Influence of dietary fiber addition on sensory and rheological properties of yoghurt. International Dairy Journal, v. 14, p. 263-268, 2004.

STATON, C.; ROSS, R.P.; FITZGERALD, G.F.; VAN SINDEREN, D. Fermented functional foods based on probiotics and their biogenic metabolites. Current Opinion in Biotechnology, v.16, p. $198-203,2005$.

STEINBERG, D. Clinical trials of antioxidants in arterioesclerosis: are we doing the rigth thing? Lancet, v. 346, p. 36-38, 1995.

TAlCOTt, S. T., PERCIVAl, S. S., PITTET-MOORE, J., CELORIA, C. Phytochemical composition and antioxidant stability of fortified yellow passion fruit (Passiflora edulis). Journal of Agricultural and Food Chemistry, v. 51, p. 935-941, 2003. 
THARMARAJ, N., SHAH, N. P. Selective enumeration of Lactobacillus delbrueckii ssp. bulgaricus, Streptococcus thermophillus, Lactobacillus acidophillus, Bifidobacteria, Lactobacillus casei, Lactobacillus rhamnosus and Propioniobacteria. Journal of Dairy Science, v. 86, p. 22882296, 2003.

TOGASHI, C. K., FONSECA, J. B.; SOARES, R. T. R. N.; GASPAR, A.; DETMANN, E. Composition of fatty acids in tissues of broilers fed by-products of passion fruit. Revista Brasileira de Zootecnia, v. 36, p. 2063-2068, 2007.

TSEN, J. H.; LIN, Y. P.; KING, E. Fermentation of banana media by using k-carrageenan immobilized Lactobacillus acidophilus. International Journal of Food Microbiology, v. 91, p. 215 220, 2004.

TURRONI, F.; RIBBERA, A.; FORONI, E.; VAN SINDEREN, D.; VENTURA, M. Human gut microbiota and bifidobacteria: from composition to functionality. Antonie Van Leeuwenhoek International Journal of General and Molecular Microbiology, v. 94, p. 35 - 50, 2008.

UMEMURAS, M.; FUJI, H.; ASANO, I.; HOSHIN, H.; INO, H. Effect of "coffee mix drink" containing mannooligosaccharides from coffee mannan on defecation and fecal microbiota in healthy volunteers. Food Science and Technology Research, v. 10, p. 195 -198, 2004.

VARGHESE, K. S.; MISHRA, H. N. Modelling of acidification kinetics and textural properties in dahi (Indian yogurt) made from buffalo milk using response surface methodology. International Journal of Dairy Technology, v. 61, p. 284-289, 2008.

VASILJEVIC, T.; SHAH, N. P. Probiotics d from Metchnikoff to bioactives. International Dairy Journal, v. 18, p. $714-728,2008$.

VASILJEVIC, T.; SHAH, N. P. Probiotics - from Metchnikoff to bioactives. International Dairy Journal, v. 18, p. 714- 728, 2008.

VINDEROLA, C. G.; COSTA, G. A.; REGENHARDT, S.; REINHEIMER, J. A. Influence of compounds associated with fermented dairy products on the growth of lactic acid starter and probiotic bacteria. International Dairy Journal, v. 12, p. 579-589, 2002.

WANG, C. W.; TSAI, C. H.; LIN, H. J.;WANG, T. C.; CHEN, H. L. Uncooked Taiwanese yam (Dioscorea alata L. cv. Tainung no. 2) beneficially modulated the large bowel function and faecal microflora in BALB/c mice. Journal of Science Food and Agriculture, v. 87, p. 1374 - 1380, 2007.

WELMAN, A. D.; I. S. MADDOX. Exopolysaccharides from lactic acid bacteria: perspectives and challenges. Trends in Biotechnology, v. 21, p. 269-274, 2003. 
WICHIENCHOT, S.; JATUPORNPIPAT, M.; RASTALL, R. Oligosaccharides of pitaya (dragon fruit) flesh and their prebiotic properties. Food Chemistry, v. 120, p. $850-857,2010$.

WU, J.; GAO, H.; ZHAO, L.; LIAO, X.; CHEN, F.; WANG, Z.; HU, X. Chemical compositional characterization of some apple cultivars. Food Chemistry, v. 103, p. 88-93, 2007.

XU, S.; BOYLSTON, T. D.; GLATZ, B. A. Conjugated linoleic acid content and organoleptic attributes of fermented milk products produced with probiotic bacteria. Journal of Agricultural and Food Chemistry,v. 53, p. 9064-9072, 2005.

YADAV, H.; J. SHALINI; SINHA, P. R. Production of free fatty acid and conjugated linoleic acid in probiotic dahi containing Lactobacillus acidophilus and Lactobacillus casei during fermentation and storage. International Dairy Journal, v. 17, p. 1006-1010, 2007.

YAPO, B. M. Pineapple and banana pectins comprise fewer homogalacturonan building blocks with a smaller degree of polymerization as compared with yellow passion fruit and lemon pectins: implication for gelling properties. Biomacromolecules, v. 10, p. 717 - 721, 2009.

YAPO, B. M.; KOFFI, K. L. Dietary fiber components in yellow passion fruit rinds - a potential fiber source. Journal of Agricultural and Food Chemistry, v. 56, p. 5880-5883, 2008.

YOON, K.; WOODAMS, E.; HANG, Y. Probiotication of tomato juice by lactic acid bacteria. Journal of Microbiology, v. 42, p. 315 - 318, 2004.

YOON, K.; WOODAMS, E.; HANG, Y. Fermentation of beet juice by beneficial lactic acid bacteria. LWT-Food Science and Technology, v. 38, n.1, p. 73 - 75, 2005.

ZHAO, G.; ETHERTON, T. D.; MARTIN, K. R.; GILlIES, P. J.; WEST, S. G.; KRISETHERTON, P. M.. Dietary $\alpha$-linolenic acid inhibits proinflammatory cytokine production by peripheral blood mononuclear cells in hypercholesterolemic subjects. American Journal of Clinical Nutrition, v. 85, p. 385-91, 2007.

ZIBADI, S.; WATSON, R. R. Passion Fruit (Passiflora edulis): composition, efficacy and safety. Evidence Based Integrative Medicine, v. 1, p. 183-187, 2004.

ZIBADI, S.; FARI, R.; MORIGUCHI, S.; LU, Y.; FOO, L.Y.; TEHRANI, P. M.; ULREICH, J. B.; WATSON, R. R. Oral administration of purple passion fruit peel extract attenuates blood pressure in female spontaneously hypertensive rats and humans. Nutrition Research, v. 27, p. 408-416, 2007. 